
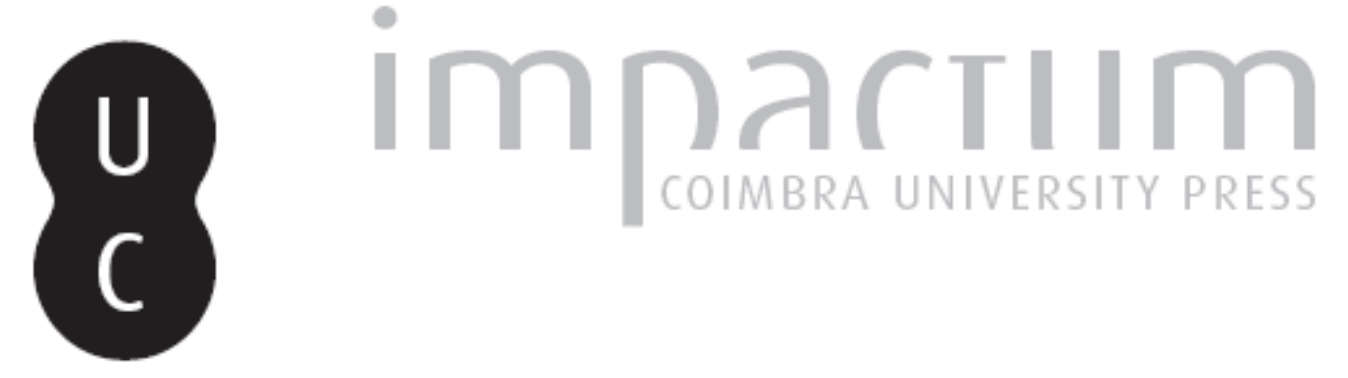

\title{
Revoltas e ideologias em conflito durante as Invasões Francesas
}

Autor(es): $\quad$ Araújo, Ana Cristina

Publicado por: Imprensa da Universidade de Coimbra

URL persistente:

URI:http://hdl.handle.net/10316.2/45070

DOI:

DOI:https://doi.org/10.14195/2183-8925_7-2_1

Accessed : $\quad$ 26-Apr-2023 13:37:42

A navegação consulta e descarregamento dos títulos inseridos nas Bibliotecas Digitais UC Digitalis, UC Pombalina e UC Impactum, pressupõem a aceitação plena e sem reservas dos Termos e Condições de Uso destas Bibliotecas Digitais, disponíveis em https://digitalis.uc.pt/pt-pt/termos.

Conforme exposto nos referidos Termos e Condições de Uso, o descarregamento de títulos de acesso restrito requer uma licença válida de autorização devendo o utilizador aceder ao(s) documento(s) a partir de um endereço de IP da instituição detentora da supramencionada licença.

Ao utilizador é apenas permitido o descarregamento para uso pessoal, pelo que o emprego do(s) título(s) descarregado(s) para outro fim, designadamente comercial, carece de autorização do respetivo autor ou editor da obra.

Na medida em que todas as obras da UC Digitalis se encontram protegidas pelo Código do Direito de Autor e Direitos Conexos e demais legislação aplicável, toda a cópia, parcial ou total, deste documento, nos casos em que é legalmente admitida, deverá conter ou fazer-se acompanhar por este aviso.

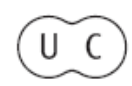




\section{REVISTA DE HISTORIA DAS IDEIAS 7}

\section{REVOLTAS E REVOLUCOẼS}

\section{**}

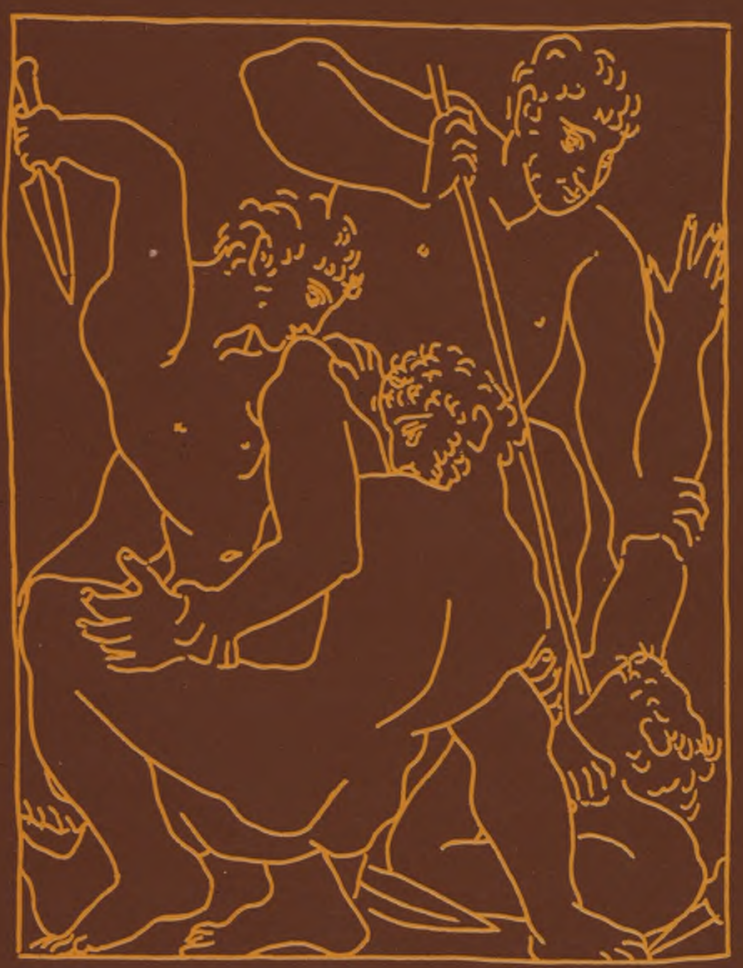

INSTITUTO DE HISTÓRIA E TEORIA DAS IDEIAS FACULDADE DE LETRAS 


\section{REVOLTAS E IDEOLOGIAS EM CONFLITO DURANTE AS INVASÕES FRANCESAS}

\section{A conjuntura de guerra}

1.1. As relações diplomáticas luso-francesas, constantemente agravadas depois da convenção de 29 de Janeiro de 1801, acabaram por arrastar inexoravelmente o país para a ocupação político-militar napoleónica. A possibilidade de anexação territorial surge já claramente formulada nessas negociações, a par da exigencia de encerramento dos portos continentais à navegação britânica 0). Independentemente das motivações que ditaram tais cláusulas, importa salientar que a ideia de ocupa-

* Faculdade de Letras da Universidade de Coimbra.

C) $O$ tratado preliminar de aliança assinado em Madrid, «para la invasion del Portugal à afecto de obrigarlo a separar-se de la Inglaterra», foi ratificado pelo tratado de Aranguez, de $21 \mathrm{de}^{\wedge}$ Março, que expressamente determinava a ocupação do território até à paz geral. Veja-se a transcrição do tratado de Madrid de 29 de Janeiro de 1801 in José Ferreira Borges de Castro, Collecção dos Tratados, Convenções, Contratos e Actos públicos celebrados entre a Coroa Portuguesa e as mais Potencias desde 1640 até ao presente, t. IV, Lisboa, 1857, pp. 522-525 e Júlio Firmino Judice Biker, Supplemento à Collecção dos tratados, convenções, contratos...., t. XIII, Lisboa, 1878; pp. 202-206. E vasta a bibliografia sobre este período da historia diplomática portuguesa. Entre outras obras salientamos: Simão J. da Luz Soriano, Historia da Guerra Civil e do Estabelecimento do Governo Parlamentar em Portugal, comprehendendo a historia diplomática, militar e política d'este reino desde 1777 até 1834. prijneira ephoca, t. II, Lisboa, 1867, pp. 313 e ss. António Viana, Introdução aos Apontamentos para a História Diplomática Contemporânea (1789-1815), Lisboa, 1907, pp. 99-156; Eduardo Brazão, Historia Diplomática de Portugal, 1640-1815, vol. 1, Lisboa, 1932, pp. 415 a 464; Manuel Pinheiro Chagas, "Guerra Peninsular», in Educação Popular "Encyclopedia Instructiva e Amena....", Lisboa, 1874, pp. 11-24. 
ção é anterior ao Bloqueio Continental decretado por Napoleão em 21 de Novembro de 1806.

Neste sexénio de atribuladas negociações e de dupla diplomacia, Portugal tenta manter-se, a todo o custo, numa posição de neutralidade perante o hegemónico conflito franco-britânico $\left({ }^{2}\right)$.

O perfil recortadamente atlântico do país e a prosperidade comercial que fruía, tornavam impossível não só o seu silenciamento como a almejada neutralidade no xadrez político internacional da época. O governo persuadido de que na base daquela disputa de supremacias, de inegável projecção colonial, estava em jogo não só a independência da metrópole como a sorte do império colonial, especialmente do Brasil, resolve repartir, de uma forma mais equilibrada, as vantagens do mercado atlântico pelas duas potências beligerantes. A França passou então a usufruir do estatuto de nação favorecida para a colocação da sua produção têxtil. $\mathrm{O}$ volume de trocas entre os dois países aumentou progressivamente até cerca de 1807, mas a posição destacada que em poucos anos assumiu no cômputo geral da nossa balança de comércio externo ficou a dever-se, em grande parte, ao peso das produções coloniais nas remessas importadas. $\mathrm{O}$ acesso por via indirecta às mercadorias fortes brasileiras - açúcar, algodão, tabaco e coiros - esbatia o efeito negativo do déficit comercial francês ${ }^{(3)}$. Se a intensidade das

C) Logo na Primavera de 1801, e apesar da situação internacional não se revelar favorável à disseminação de focos de confronto a escala europeia, Portugal sofria o primeiro embate da estratégia imperialista francesa. $O$ aspecto mais peculiar deste agravamento de tensões reside no facto de a vizinha Espanha abdicar do seu papel de medianeira dos interesses peninsulares para se assumir como força interessada no conflito. Esta inflexão de política internacional da monarquia espanhola foi habilmente negociada e dirigida pelo influente ministro de Carlos IV, D. Manuel Godoy. Na sequência do tratado de aliança franco-espanhol inicia-se a mobilização para a guerra. A confrontação entre as forças coligadas e o exército português, embora limitada à província alentej ana, acabaria por implicar a perda da praça de Olivença e consequentemente a redefinição da fronteira sul do país. Nessa ocasião, o governo de Jorge III anuiu ao encerramento dos portos portugueses à navegação britânica mas recusou-se a expedir contingentes militares para a guerra que estava iminente. A prioridade da defesa de Malta, Egipto e Itália relegava para um plano secundário a ajuda à nação aliada. A falta de meios, a deficiente preparação do nosso exército para suportar o prolongamento da guerra e, sobretudo, o isolamento a que fomos remetidos forçaram a assinatura da paz. A indemnização imposta nas negociações de Setembro de 1801 imnortava em 16 milhões de francos. Vide António Viana, ob. cit., pp. 100-105 e 116-117.

(3)

Albert Silbert, Do Portugal do Antigo Regime ao Portugal Oitocentista, Lisboa, 1977. pp. 55-57; Jorge Borges de Macedo, O Bloqueio Continental, economia e guerra peninsular, Lisboa, 1962, pp. 38-39. 


\section{Revoltas e Ideologias}

relações económicas explica, apesar dos inúmeros incidentes diplomáticos, a relativa complacência da política francesa até sensivelmente 1805, não devemos, contudo, esquecer que 1801 representa o primeiro teste da estratégia expansionista francesa na península. A missão de que Berthier fora encarregado em 1800, em Madrid, «levar por todos os meios possíveis a Espanha a uma guerra contra Portugal» $\left({ }^{4}\right)$, traduz, de facto, o alcance estratégico e projectivo dos incidentes militares e diplomáticos do princípio do século. Ficava definitivamente demonstrado que Portugal e Espanha jamais poderiam formar causa comum a pretexto de exigências idênticas. A definição da política de alianças por parte dos países ibéricos permitia, assim, adiar a clarifícação do conflito mundial que opunha as duas grandes potências ocidentais. Interessava tão-só à França garantir e premiar nos anos subsequentes a rivalidade agravada, pois que, desse modo, se invalidava definitivamente qualquer possibilidade de uma aliança ibero-britânica.

Apostando no enfraquecimento do vigor expansionista napoleónico, de que começava a dar mostras em vésperas do Bloqueio Continental, concretamente com a derrota de Trafalgar em 1805, Portugal e a Inglaterra consideravam cada vez mais remota uma ofensiva naval francesa.

Enquanto a confiança reinava na corte de Lisboa, a Espanha de Carlos IV, através do ministério Godoy, impõe pesadas exigências pelo apoio da sua esquadra naval aos exércitos imperiais. O plano então gizado previa, como prémio, a anexação e partilha do espaço continental e colonial português $\left(^{5}\right)$. Colocado perante as duas estratégias imperialistas da coligação franco-espanhola, D. João VI resiste evasivamente às primeiras e insistentes intimidações do embaixador Junot, em Lisboa $\left(^{6}\right)$.

(4) Albert Silbert, ob. cit., p. 49.

(5) O plano que viria a conhecer forma de letra no [Tratado de Fontainebleau previa a divisão do território português em três partes: o norte do país constituído pelas províncias de Douro e Minho, a Lusitânia Setentrional, destinava-se ao rei da Etrúria, um neto de Carlos IV, em compensação da cessão da iToscana que passaria a integrar as fronteiras francesas; o principado dos Algarves e as índias Portuguesas seriam confiadas à Espanha e o centro do país ficaria sob a tutela napoleónica. Cf. António Viana, ob. cit., p. 149, e S. J. da Luz Soriano, ob. cit., primeira éphoca, t. II, pp. 655-657.

C) Em Março de 1805, o governo apercebe-se que Napoleão se prepara para recomeçar as hostilidades. $O$ teor da carta que o Imperador remete para Lisboa é o seguinte: «Sereníssimo e muito amado bom-irmão e primo, aliado e confederado. - A presente carta será entregue a $V$. A. R. pelo general Junot, meu ajudante de ordens, comandante dos meus hussards e meu embaixador junto de V. A.. Encarreguei-o muito especialmente de afirmar a V. A. R. o interesse 
É sob a ambiência psicológica de uma guerra iminente que o país vive até à declaração formal de 17 de Julho de 1807, comunicada por Talleyrand a Lisboa $\left({ }^{7}\right)$.

Em Outubro as tropas associadas, concentradas em Baiona, começam a dirigir-se para a fronteira portuguesa. Irremediavelmente colocado perante a ameaça das baionetas, o príncipe regente adere ao bloqueio em 27 de Setembro. Mas enquanto em Fontainebleau Godoy e Napoleão projectam a partilha da nova presa, Portugal e a Inglaterra negoceiam secretamente uma convenção que previa, nomeadamente, a transferência da sede da monarquia para o Brasil e a ocupação da ilha da Madeira por tropas britânicas, pelo tempo que durassem as operações militares no continente $\left(^{8}\right)$.

que dedico à prosperidade da Coroa de Portugal, e a esperança que tenho de que os nossos dois estados hão-de caminhar conformes, para chegarem ao grande resultado do equilíbrio dos mares, ameaçado pelos abusos de poder e pelas vexações que os ingleses cometem, não só para com a Espanha, mas ainda para com todas as potências neutrais. As promessas que tenho recebido de V. A. R. em todas as ocasiões são um seguro penhor de que nos entenderemos para fazer o maior dano à Inglaterra e obrigá-la assim a ideias mas sãs e mais moderadas. Fique V. A. convencido dos meus sentimentos de estima e de inviolável amizade; alem de que sereníssimo e muito amado bom irmão e primo, aliado e confederado, peço a Deus que vos tenha em santa e digna guarda.... Napoleão: - Malmaison, 30 Pluviôse, anno 13, (J. Biker, ob. cit., t. 14, p. 116).

(7) A Inglaterra prepara-se para a guerra com antecedência. Em Agosto de 1806, o porto de Lisboa é escalado pela esquadra do almirante Rosslyn. Alarmado, o ministério recusa a sua ajuda militar e financeira e acrescenta que a presença da armada inglesa «tinha na praça de Lisboa produzido a maior consternação e espanto, prejudicando o comércio e fazendo subir o ágio, além das gravíssimas contestações diplomáticas em que tudo isto ia meter a corte de Lisboa com a de Madrid e Paris, pondo em grande risco a segurança de Portugal, em vez de concorrer para a sua defesa e independência». (J. Biker, ob. cit. t. 14, p. 201). No entanto, «o estudo dos portos portugueses permite-nos responder com toda a segurança, que, apesar das várias intimidações francesas para que Portugal cessasse as comunicações comerciais com a Inglaterra, estas continuaram, quase com a mesma intensidade e só com uma interrupção (e não total) de meses». (J. B. de Macedo, ob. cit., pp. 59-60).

(8) J. F. Borges de Castro, ob. cit., t. 4, p. 236. A ocupação da Ilha da Madeira em 1807, tal como já acontecera em 1801, fora devidamente apoiada pela imprensa britânica afecta aos interesses da burguesia mercantil daquele país. Só em 1814 a Madeira foi abandonada pelo exército aliado. Também Goa. sitiada em 1801, ficou sob o controlo inglês de Dezembro de 1802 a Abril de 1813. Cf. S. J. da Luz Soriano, ob. cit., primeira ephoea, t. II, pp. 678-698 e primeira época, t. III, pp. 626-640. Na década de vinte a opinião liberal exploraria em desfavor do governo absolutista de D. João VI, estas e outras concessões feitas, na altura, à nação aliada. Liberato Freire de Carvalho interrogava-se mes- 
1.2. Os eixos de comunicação do império português alteraram-se radicalmente com a retirada da corte, em finais de Novembro, para terras de Santa Cruz. A pequena parcela do continente torna-se periférica, política e economicamente, em relação à antiga colónia americana. A macrocefalia imperial de princípios do século preludiará, a breve trecho, a primeira grave crise colonial portuguesa e, a par dela, a imperiosa necessidade de uma mutação política de conotação liberal.

Independentemente das relações de forças internacionais que ditaram esta solução parece, a priori, poder inferir-se que a alteração dos centros de decisão do império, sugerida em 1801 e concretizada em 1807, culmina o ainda mal conhecido movimento de emigração para aquela colónia - intensificado seguramente durante todo o século XVIII - e acompanha de perto o sistema de investimento da burguesia mercantil ligada ao eixo Lisboa - Rio de Janeiro.

Se as recomendações, em 1801, do marquês de Alorna e de D. José Manuel de Sousa, o morgado de Mateus, no sentido da transferência da sede da monarquia para o Brasil tinham o alcance de solução de emergência, tal como assim o encarava o embaixador português em Paris, o Conde da Ega, em vésperas da $1 .^{\text {a }}$ invasão francesa $\left({ }^{9}\right)$, já na perspectiva do ministro D. Ro-

mo se a defesa e protecção da dinastia de Bragança não teria sido possível com a fuga da corte não para o Brasil mas para a Madeira, e acrescentava: «não será temerário dizer-se que esta fugida para o Brasil não foi só uma consequência de cobardia por parte do ministério que então formava o governo de Lisboa, mas uma combinação premeditada do governo britânico para se ir apoderar do comércio do Brasil - o visconde Palmerson confessou publicamente isso na sua $^{\wedge}$ fala contra D. Miguel no $1 .^{\circ}$ de Junho de 1829 - .... o governo britânico mostrando-se então muito satisfeito com esta resolução, apoderava-se com o seu costumado desinteresse da nossa importante ilha da Madeira, quando em todo o caso, uma vez que o reino caísse para sempre no poder de Napoleão, ganhar mais essa nova posição maritimo militar à custa do pobre Portugal .... Para que esta conquista fosse firme, levantou n'ela a sua bandeira, e cuidou logo em a fortificar com uma numerosa guarnição» (José Liberato Freire de Carvalho, Ensaio Historico-Politico sobre a Constituição e governo do Reino de Portugal, Paris, 1830, pp. 157-158). De facto, a solução encontrada pela regência de $D$. João $V I$ de há muito vinha sendo preparada pela corte britânica. Veja-se a este respeito, Discurso do Immortal Guilherme Pit. (Mandado imprimir por hum apaixonado da Nação). Pronunciado poucos annos antes do seu falecimento, no Parlamento Imperial dos Reinos Unidos da Gram Bretanha e Irlanda. Contem reflexões e prognósticos dignos de perpétua lembrança dos veneradores deste Grande Homem de Estado, Lisboa, s.d.

(9)

A ideia de transferir a sede da monarquia para o Brasil remonta à época da Restauração. D. António, prior do Crato, pretendente ao trono em 1580, chegou a esboçar o plano reto- 
drigo de Sousa Coutinho, que influentemente dirigiu este processo, o mesmo se não pode afirmar. A directriz colónio-cêntrica atlântica do futuro conde de Linhares, fundamentalmente condicionada pela vitalidade do tráfego ultramarino $\left({ }^{10}\right)$, tinha pressuposta a subalternização geo-económica do espaço continental europeu. Neste contexto, compreende-se melhor à luz do entendimento que este ministro tinha do sistema imperial português - ao considerar que «Portugal não era nem a melhor nem a mais influente parte da monarquia» — o seu projecto de organização federativa do império ( $\left.{ }^{n}\right)$. Através da reconversão dos seus centros de decisão político-económicos tentava dinamizar o sistema de trocas coloniais fazendo refluir a capacidade de investimento

mado depois, mas sem concretização, por António Vieira. No século XVIII, o embaixador D. Luís da Cunha, nas suas Instruções a Marco António de Azevedo Coutinho relança esse projecto que o Marquês de Pombal chegou a admitir preparando para o efeito uma esquadra adequada aquando da guerra de sucessão de Espanha.

$\mathbf{E}$ a este respeito interessante, a visão do Conde da Ega sobre o impacte e as consequências da retirada da corte para o Brasil em 1807 - «Ou Portugal há-de fechar os seus portos aos ingleses e correr o risco de perder por algum tempo a posse das suas colónias, ou o Príncipe Nosso Senhor, abandonando o seu reino na Europa, ganhado e conservado pelo suor dos seus antepassados, irá estabelecer no Novo Mundo uma nova Monarquia que, bem que possa vir a ser um império de maior consideração, produzirá uma semelhante medida a maior de todas as revoluções no sistema geral político",, (in História de Portugal, dirigida por José Hermano Saraiva, vol. 5, Lisboa, 1984, p. 128). (sublinhado nosso). Implicações que escapando ao entendimento da maioria dos contemporâneos, foram também, clarividentemente apontados por José Agostinho de Macedo em cinco proposições: $10^{\mathrm{a}}$ - Forçada a emigração do Principe Regente deixou o Portugal europeu em estado de nấo poder ser reino independente, nem continuando a guerra, nem depois de feita a paz; $2 .^{\mathrm{a}}-$ No estado da paz, Portugal desmembrado do Brasil não pode ser uma monarquia; 3. a-Portugal, assim como as outras naçóes civilizadas da Europa, não pode ser reduzido ao estado primitivo; $4 .^{\mathrm{a}}$ - Com a guerra feita ao comércio não se abate a Inglaterra; os seus recursos se estenderão até ao infinito pela emigração do Principe de Portugal; 5. ${ }^{\text {a }}$ - Portugal, pela emigração do Principe, fica o mais desgraçado de todos os povos, $e$ inútil a todas as potências." (in Obras Inéditas de José Agostinho de Macedo. Cartas e opúsculos documentando as memorias para a sua vida intima e sucessos da Historia litteraria e politica do seu tempo. Com uma prefação critica por Teophilo Braga, Lisboa, 1900, pp. 297-313).

(10) O comércio externo português atravessa uma fase de expansão de 1785 a 1808 . O estudo da nossa balança comercial, para este período, revela apenas dois anos deficitários, em 1797 e 1799. Vide J. Borges de Macedo, ob. cit., pp. 38-42; e Albert Silbert, ob. cit., pp. 42-44.

(") Robert Kenneth Maxwell, Conflits and Conspiracies: Brazil and Portugal, 1750-1807, Cambridge, 1982, cap. VIII, pp. 35-47; Cf. Fernando A. Novais, Portugal e Brasil na crise do Antigo Sistema Colonial (1777-1808), 2. ${ }^{a}$ ed., S. Paulo, 1983, cap. III. 


\section{Revoltas e Ideologias}

da burguesia, de grosso trato, para uma metrópole potencialmente mais promissora. Esta via fora pensada igualmente como processo de travagem de uma eventual tentativa de autonomização da colónia brasileira - o exemplo da América do Norte produziria, neste enquadramento, um eco político reduzido.

Difícil de materializar numa conjuntura de guerra, este projecto tornava-se ainda mais arriscado na situação de forte dependência económica em que o mercado atlântico português se encontrava em relação à Grã-Bretanha. De facto, essa dependência viria a ser reforçada com as medidas tomadas no Rio de Janeiro, sob pressão do governo inglês, tendentes à liberalização do comércio intercontinental. Dois anos depois do decreto de 28 de Janeiro de 1808, que estabelecia um sistema de trocas livres e directas entre o Brasil e a Inglaterra, foi assinado o conhecido tratado de 18 de Fevereiro de 1810 , que reduzia a $15 \%$ todos os direitos pagos pelas mercadorias inglesas quer no Brasil quer no continente, com excepção para os artigos de lã (que só em 1814 foram submetidos a esta taxa) (12).

A orientação livre-cambista do Rio de Janeiro visava acautelar os interesses imediatos da burguesia mercantil ligada ao Brasil. Esta directriz deve portanto, compreender-se também em função da derrama de gentes e dinheiro que ocorreu em $\left.1807{ }^{(13}\right)$. São numerosos os testemunhos coevos que genericamente nos referem importantes movimentos de saída de «gente de cabedais»» da costa litoral portuguesa.

Acúrsio das Neves dá-nos conta da «sangria de gentes e dinheiro» que então se operou: «eram muitos os que pretendiam embarcar e poucos navios. Aqueles mesmos que posteriormente foram emigrando de Portugal achavam na esquadra inglesa os auxílios necessários para se transportarem à Inglaterra, ao

(12) S. J. da Luz Soriano, ob. cit., primeira ephoca, t. III, pp. 577-580; Oliveira Lima, D. João VI no Brasil, vol. 2. ${ }^{\circ}$, Rio de Janeiro, 1945 , pp. 385 e ss.

(13) Mariano Miguel Franzini, nas Reflexões sobre o actual Regulamento, Lisboa, 1820, calcula em 15 mil o número dos que então partiram sem contudo, discriminar a condição social desses foragidos. Cremos, no entanto, que a fuga de pessoas foi condicionada pela fuga de capitais tanto para o Brasil como para a Inglaterra. Durante os primeiros meses da ocupação francesa, Junot informava Napoleão (18 de Janeiro de 1808) que tinham saído de Portugal cerca de 5 milhões em numerário, grande parte com destino a Inglaterra, (Diário de Junot, in Christovam Ayres de Magalhães Sepulveda, História orgânica e política do exército português, vol. XII, Coimbra, 1917, p. 150). Cf. a propósito dos negociantes portugueses estabelecidos em Londres neste período, Georges Boisvert, Un Pionnier de la Propagande Libérale au Portugal: João Bernardo da Rocha Loureiro, (1778-1853), Paris, 1982, pp. 142-149. 
Brasil ou àqueles lugares que as circunstâncias permitiam: os que aportaram à Inglaterra, lá mesmo foram encontrar socorros pecuniários com que se lhes mandou assistir por intervenção do embaixador português em Londres, D. Domingos António de Sousa Coutinho, chegando esta despesa a 58000 lb. St. (522 000 cruzados) e a 2000 o número de vassalos portugueses que por ali transportaram para o Brasil» $\left({ }^{14}\right)$.

Outro contemporâneo, Ricardo Raimundo Nogueira fala do «susto que tem induzido os negociantes e capitalistas a tirarem do reino os seus cabedais, e até a emigrarem em bastante número para Inglaterra e para o Brasil» $\left({ }^{15}\right)$.

Há, portanto, indícios de fuga de capitais e de uma forte mobilidade da burguesia mercantil a partir dos preparativos da primeira invasão francesa. $O$ arrolamento de negociantes nacionais das duas mais importantes praças do país, entre 1807 e 1820, permite-nos, sem profundidade, acompanhar esse movimento (16). O almanaque de Lisboa de 1807 menciona para a capital 288 negociantes; a mesma fonte, para 1820, dá-nos precisamente mais um negociante. Aparentemente o cenário mercantil da capital parece não se ter alterado, o que não é verdade. Comparando o nome dos negociantes arrolados verifica-se que só se mantêm na cidade do Tejo 59 mercadores no período mencionado. Os restantes 229 nomes que encontramos em 1807 dão lugar a outros tantos desconhecidos. Na praça do Porto, o número dos homens de negócio diminuiu de 208 em 1807 para 164 em 1820. E aqui também, só 31 firmas se mantêm ligadas aos mesmos proprietários. Valeria a pena confirmar esta constatação com dados fornecidos por outras fontes. De qualquer forma, poderemos provisoriamente concluir que novas fortunas surgem num lapso conjuntural marcado pela retracção do comércio externo metropolitano enquanto outras desaparecem. Foi no relançamento da faina marítima e sobretudo no contrabando que provavelmente as novas fortunas se alicerçaram.

(14) José Acúrsio das Neves, História Geral da Invasão dos Franceses em Portugal e da Restauração deste Reino, 2.a ed., in Obras Completas, $10^{\circ}$ e 2..$^{\circ}$ vols., Estudos introdutórios de António Almodovar e Armando de Castro, t. I, Porto, s.d., p. 219.

(15) Ricardo Raymundo Nogueira, Situação Financeira de Portugal em 1811, in Christovam Ayres de Magalhães Sepulveda, ob. cit., vol. X, Lisboa, 1913, p. 80.

(If) A fonte que utilizámos fornece-nos os nomes dos proprietários, dos estabelecimentos e sua localização. (Trata-se dos Âlmanaques de Lisboa que foram publicados com um ritmo irregular no período que considerámos. Apenas saíram dos prelos os números correspondentes aos anos de 1807, 1812, 1814, 1817 e 1820. Cf. Inocêncio Francisco da Silva e Brito Aranha, Diccionario Bibliographic o Portuguez, t. 1, Lisboa, 1758, p. 44. 


\section{Revoltas e Ideologias}

1.3. Se nos fixarmos em 1808 verificamos, num relance rápido, que os efeitos da ocupação francesa foram directamente sentidos por todas as classes sociais. Antes de findar $\mathrm{o}$ ano de 1807 já Lisboa se despovoava. «A população de Lisboa calculava-se em 280 a 300 mil almas; mas julgo que se pode afirmar sem exageração, que ela tem diminuído de 15 de Novembro para cá [29 de Dezembro] em mais de 70 mil pessoas, principiando pela saída dos Ingleses a que se seguiu o decreto para se thes fecharem os Portos e, em consequência o bloqueio que paralisou o comércio, a saída da esquadra que levou imensa gente e, deixou outra sem meios de subsistência.... Esta despovoação há-de continuar ainda até que os habitantes se reduzam ao número proporcionado às circunstâncias e qualquer que seja o nosso último destino é provável que Lisboa nunca chegue a ser tão populosa como dantes era, sendo certo que ela tinha demasiada gente, e a sua grande povoação era efeito de vícios da administração e não de causas materiais.... há mais de 8 dias que ouvi que só pela Intendência Geral da Polícia se tinham dado 11000 passaportes. Muitas famílias aqui estabelecidas tem-se retirado para o campo outras para as províncias» $\left({ }^{17}\right)$.

$\mathrm{O}$ aumento da procura de bens essenciais aliado aos efeitos devastadores da guerra e ao cancelamento das importações reflecte-se, de imediato, na subida incontrolável dos preços. Em Março de 1808, o redactor do Dietário de S. Bento assinalava «a falta de alguns géneros de primeira necessidade» e para o mês seguinte registava os seguintes preços - «o trigo está a $1200 \mathrm{e}$ 1400 o alqueire; o azeite a 3000 e 5200 por almude; o feijão a 1000 e 1100 e o mais à porção: manteiga 550 e a 600» e acrescentava «o peixe fresco nem por exorbitante dinheiro» $\left({ }^{18}\right)$.

Acentua-se o carácter rural da sociedade portuguesa; a indigência aumenta; entre as classes possidentes que ficam generaliza-se a tendência para o entesouramento e a vertigem da venda de bens, a qualquer preço; a actividade fabril abranda e nalguns casos suspende-se mesmo.

Para a paralisia económica do reino contribuíram ainda as pilhagens e requisições da tropa invasora, o sequestro dos bens ingleses e de todas as mercadorias de origem britânica em poder dos negociantes, para além da imposição de avul-

(7) Ricardo Raymundo Nogueira, Apontamentos, in C. A. de Magalhães Sepulveda, ob. cit., vol. X, Lisboa, 1913, p. 66.

(18) Dietário do Mosteiro de S. Bento, in C. A. de Magalhães Sepúlveda, ob. cit., Lisboa, 1913, pp. 310-312. 


\section{Revoltas e Revoluções}

tadas contribuições extraordinárias e de guerra, parcialmente executadas $\left({ }^{19}\right)$.

Associada a esta política de saque, Junot desarma o país tentando, em vão, silenciar quaisquer manifestações de hostilidade e revolta $\left({ }^{20}\right)$.

\section{Ocupação e afrancesamento}

2.1. A primeira invasão não teve ao nível do aparelho do Estado um efeito demolidor nem sequer corrosivo. Sem resistência, se apoderaram os invasores do poder central e da administração provincial.

O primeiro tempo do sitiamento militar do país correspondeu, no plano político, a um compromisso governativo em que, todavia, a supremacia francesa foi manifesta. $O$ carácter impositivo e estranho deste governo acentuou a tendência centralista do Estado Absoluto revelada pela macrocefalia das instituições fiscais, judiciais e administrativas. Em rigor, esse compromisso governativo que envolveu a oficialidade francesa, as autoridades portuguesas e representantes espanhóis, isto é, os emissários do príncipe da paz, estende-se de 30 de Novembro de 1807, data em que Junot se estabelece em Lisboa, a 1 de Fevereiro, quando é dissolvido o Conselho de Regência e formalmente abolida a soberania do príncipe D. João VI sobre o território continental — $\ll$ o reino de Portugal passaria a ser administrado todo inteiro, e governado em nome de S. M. o imperador dos franceses, pelo General em chefe do exército francês em Portugal» $\left({ }^{21}\right)$.

(19) Pelo decreto de 3 de Dezembro de 1807, Junot determinava uma contribuição de guerra de dois milhões de cruzados. Pouco depois, em Milão, o Imperador impunha ao país uma derrama de quarenta milhões de cruzados. Vide C. A. de Magalhães Sepúlveda, ob. cit., vol. XVII, Coimbra, 1932, pp. 141-146 e pp. 221-222.

(20) S. J. da Luz Soriano, ob. cit., segunda ephoca, t. I, Lisboa, 1870, p. 185. Vide diplomas de 22 de Dezembro de 1807 e de 11 de Janeiro de 1808, in C. A. de Magalhães Sepúlveda, ob. cit., vol. XII, pp. 122-123, 140 e 179.

(21) Decreto de 1 de Fevereiro de 1808 in Colecção de Decretos $e$ Editaes, s.l., s.d. Este diploma é de maior importância para a compreensão da estratégia napoleónica em relação à península ibérica dado que traduz, na prática, a anulação de uma das cláusulas fundamentais do 'Tratado de Fontainebleau, a que previa a partilha e anexação do território português, principalmente pelos impérios Francês e Espanhol. Daí que se possa com segurança afirmar que a declaração formal de Napoleão em 27 de Abril de 1808 apenas vinha confirmar esta disposição antecipadora que salvaguardava totalmente a indivisibilidade do espaço continental. 
Neste lapso de tempo, Junot impõe um governo de protectorado que não excluía a capacidade executiva das autoridades portugueses e que, embora limitando-a, não anulava a autonomia provincial ensaiada por D. Francisco Taranco Llano no norte e por D. Francisco Solano Ortiz de Rozas, marquês do Socorro, nas províncias do Alentejo $\left({ }^{22}\right)$.

Depois da campanha aterrorizadora dirigida por Junot no decurso da sua marcha para Lisboa, campanha assente em ameaças de destruição de vilas, aldeias e de penas de morte a indivíduos implicados em actos de resistência $\left({ }^{23}\right)$, a oficialidade francesa promete, ao instalar-se no poder, não já acções de retaliação mas, sobretudo, protecção. E nesta inflexão do discurso político do invasor insiste-se que o objecto da ira napoleónica não são «os vassalos desprotegidos» de D. João VI mas a «maligna influência de Inglaterra» $\left({ }^{24}\right)$.

A conveniência política desta declaração de protecção prende-se com a certeza, obtida na capital, de uma real disponibilidade dos ministros portugueses em cooperarem com os agen-

(22) A entrega do governo das províncias do Norte e do Sul do país a dois representantes da monarquia espanhola vinha também no seguimento do que estipulava o (Tratado de Fontainebleau. Torna-se a este respeito curioso notar as diferenças de conduta política de D. Taranco Llano e do Marquês de Socorro. «D. Taranco não se intrometia no governo civil, deixando pacificamente aos tribunais e ministérios o uso da jurisdição que tinham em nome do nosso legítimo soberano. Criou sim um novo tribunal de fazenda, mas composto de portugueses.... Quando era precisado a falar nas suas ordens dirigidas a portugueses em sua Magestade Católica, era sempre com grande melindre». No Alentejo e Algarve «o Augusto Nome de S. A. R. foi substituído pelo de S. M. C. e Solano passou não só a governar as armas destas províncias, mas a legislar em nome do monarca espanhol sobre a justiça, finanças e todos os mais objectos da administração pública. Serviu-se na verdade dos governadores e mais funcionários públicos que achou estabelecidos, mas debaixo da autorização do novo governo. Como cessava a jurisdição da Casa da Suplicação para estas províncias, criou um juiz maior com superioridade a outros magistrados, e nomeou para este importante cargo D. José Maria Sotello.... Este mesmo homem entrou da sua parte a legislar sobre diferentes pontos da economia e justiça de forma que o general, de acordo com o juiz maior, fizeram com as suas novas instituições nas províncias, que dominavam mudanças mais essenciais nas leis e nos usos da nação do que o próprio Junot em Lisboa». (José Acúrsio das Neves, Historia Geral da Invasão dos Franceses em Portugal e da Restauração deste Reino, 2. ${ }^{a}$ ed., Porto, s.d., t. I, pp. 290 a 294).

$\left.{ }^{23}\right)$ Vide «Proclamação que o general Junot dirigiu aos portugueses por occasião da sua entrada em Alcântara», in S. J. da Luz Soriano, ob. cit., Segunda ephoca, t. V, parte I, pp. 1 e 2.

(24) José Acúrsio das Neves, ob. cit., t. I, p. 243. 


\section{Revoltas e Revoluções}

tes invasores na gestão do aparelho de Estado (25). De facto, o Conselho de Regência, «instituição de direito público complementar da monarquia hereditária» $\left.{ }^{26}\right)$, não só permitiu que a sua composição fosse alargada, com a entrada, em 1 de Dezembro de 1807, de Francisco António Herman, representante francês, como procedeu, sem reservas, à execução das disposições político-militares e fiscais de Junot. $\mathrm{Na}$ Intendência Geral da Polícia manteve-se, até 25 de Março, o afrancesado Lucas Seabra da Silva e, de uma maneira geral, os tribunais régios, conservando a sua antiga composição e jurisdição, mostraram-se hábeis em articular as antigas leis do reino aos interesses imediatos do general francês.

2.2. Este amplo colaboracionismo que atingiu também, e de uma forma peculiar, as mais altas dignidades da Igreja sugere que o fenómeno do afrancesamento em Portugal obedece a uma dinâmica tendencialmente diferente da observada em Espanha $\left({ }^{27}\right)$. Nos processos de afrancesamento dos países ibéricos existem pontos de coincidência e, em parte, alguns pressupostos comuns.

A par de um afrancesamento de convicção ideológica, de que faiaremos adiante, existiu outra via de aproximação ou

(25) Já às portas de Lisboa, em Sacavém, Junot recebera os cumprimentos de uma delegação da Regência composta pelo tenente-general Martinho de Sousa Albuquerque e Alte e pelo brigadeiro Francisco de Rorja Garção Stockier e recebeu uma escolta de trinta praças da Guarda Real da Polícia, expedida pelo Conde de Novion, emigrado francês e presidente daquela corporação. S. J. da Luz Soriano, ob. cit.y segunda ephoca, t. I, p. 11. Victoriano J. Cesar, Invasões Francesas em Portugal, l. ${ }^{a}$ parte. Invasão Franco-Espanhola de 1807, Roliça e Vimeiro, Lisboa, 1904, pp. 44-45.

(M) Artigo «Regência», in Dicionário de História de Portugal, dirigido por Joel Serrão, 1975, vol. 5, p. 248. Por decreto de 26 de Novembro de 1807 o príncipe regente nomeou para o Conselho de Regência, o Marquês de Abrantes, Regedor de Justiças; o tenente general Francisco da Cunha de Meneses; o principal Castro; Pedro de Melo Breyner, presidente do Erário; e o tenente general Francisco Xavier de Noronha. Na falta de qualquer destes previa-se como governador substituto o Conde de Castro Marim. Para secretários eram nomeados: o conde de Sampaio, D. Miguel Pereira Forjaz e João António Salter de Mendonça, desembargador do Paço e procurador da Coroa.

(2T) Vejam-se entre outras obras: M. Méndez Bejarano, Historia política de los afrancesados, Madrid, 1912; Miguel Ar tola, Los Afrancesados, Madrid, 1976, Hans Juretschke, Los Afrancesados en la Guerra de la Independencia, Madrid, 1962; J.-R. Aymes, La Guerre D'Indépendance Espagnole (1808-1814), Paris - Bruxelles - Montréal, 1973. 


\section{Revoltas e Ideologias}

melhor, de (falsa) identificação à política imperial francesa, isto é, a via do colaboracionismo. Tal como em Espanha, o primeiro grupo é em proporção inferior. Em contrapartida, o segundo, o dos colaboracionistas, atinge entre nós uma extensão inusitada, podendo divisar-se na sua composição um avultado número de agentes da burocracia estatal, sem distinção hierárquica e de membros da Igreja, bem colocados. Este tipo de afrancesamento, concretamente durante a primeira invasão, não tem imediata correspondência com o grupo dos juramentados espanhóis que cumpriram as ordens que receberam (do governo intruso) sem discutir a sua origem ou legalidade, normalmente temendo a repressão e procurando sobreviver à prova, numa palavra, agindo por mero oportunismo $\left({ }^{28}\right)$.

É certo que entre os colaboracionistas portugueses que apoiaram e fizeram executar as disposições políticas de Junot, em 1807 e 1808 e principalmente de Soult em 1809, podemos encontrar algumas personalidades com fortes traços de identificação aos juramentados do país vizinho (29) mas, no seu conjunto, e num primeiro momento, este tipo de afrancesamento, pela sua origem e intenção, é substancialmente distinto. Os seus protagonistas actuaram em conformidade com as instru-

(28) Miguel Artola, ob. cit., pp. 53 e 54.

$\left({ }^{29}\right)$ Estão neste caso alguns dos nomes referidos num documento anónimo expedido pelo ministro português em Londres, D. Domingos António de Sousa Coutinho, para o príncipe regente no Brasil. É certo que os propósitos que moviam aquele ministro a fazer estas revelações se prendem com velhas animosidades para com o ex-ministro da Guerra e dos Estrangeiros, António de Arraújo de Azevedo, mas nem por isso a denúncia deixa de ser reveladora neste passo: «O povo geralmente se queixa das seguintes pessoas: de António de Araújo de Azevedo e José Egídio Alvares, ambos eles no Brasil; dos oficiais da Secretaria Tomé Barbosa, Joaquim Guilherme da Costa Posser e Francisco Gomes; dos conselheiros da fazenda Domingos Vandelli e Francisco Soares de Araújo; e do médico da real camara Francisco José Pereira. Todos os referidos eram amigos íntimos de António de Araújo, e todos os que ficaram em Portugal se distinguiram debaixo do governo francês com insultos ao principe e aos seus vassalos. Foram singulares os seguintes: Pedro de Melo Breyner, conselheiro de estado, debaixo de Herman.... o Conde de Sampaio debaixo de Lhuyt; o ex-ministro José Seabra da Silva, que organizou a Junta dos Três Estados em forma de corte e fez para Junot o regimento dos corregedores mores; o conde da Cunha, aliás tão obrigado a sua alteza; e Francisco de Azevedo, conselheiro da fazenda, sendo este que fez o plano da distribuição dos quarenta milhões». (S. J. da Luz Soriano, ob. cit., segunda ephoca, t. I, pp. 638-639). Veja-se também Sentença a favor do Justificante Pedro de Mello Breyner, Lisboa, 1810. 
ções fixadas pelo príncipe regente, antes da sua travessia do Atlântico, em 26 de Novembro de 1807, e que na opinião de um informado contemporâneo «ficaram servindo de lei fundamental do governo do reino» $\left({ }^{30}\right)$. A cabal observância dessas recomendações, que prescreviam bom acolhimento e colaboração, implicava não só a permanência e conservação de cargos públicos como até outros compromissos. A prática política dos colaboracionistas inscreve-se assim nesta linha de orientação. Portanto onde se tem injustamente lido servilismo ao invasor nós lemos fidelidade à realeza livre e voluntariamente ausente no Brasil. Os próprios invasores pressentiram a duplicidade e o artificialismo dos seus mais directos colaboradores internos: «On n'etait tenu á rien envers les français; ainsi il ne pouvait pas y avoir de malveillance: ce sentiment suppose l'existence de liens réciproques. On leur témoignait l'indignation et la haine auxquelles uniquement ils s'étaient acquis des droits incontestables, et qu'ils n'ont fait que mériter de plus en plus par la suite. Les membres de la régence étaient animés de ces sentiments comme le reste des habitants; mais, chargés expressément par le prince d'éviter toute effusion de sang, ils eurent la force d'âme de les assoupir au fond de leurs coeurs, et la fermeté de les comprimer dans les autres. Dans cette transition extraordinaire, la force n'était rien; l'opinion était tout, et ce fut encore un bienfait de S. A. R. de confier en parttant son autorité à des hommes qui jouissaient de la plus haute consideration de la nation» $\left({ }^{31}\right)$.

Ora o colaboracionismo foi em 1807 e 1808, uma prática legal que se revelou tão efémera quanto o fora a adesão da Casa de Bragança ao sistema continental. Por isso, e sempre em obediência ao poder absoluto, as classes dominantes seguiram sintónicamente a orientação política da Corte em relação

(30) J. A. das Neves, ob. cit., t. I, pp. 220 e 254. Das recomendações aos governadores do Reino parecem-nos essenciais as seguintes: I. «cuidariam com todo o desvelo, vigilância e actividade na administração da justiça, distribuindo-a imparcialmente e conservando em rigorosa observância as leis deste reino.... V. Cuidariam em defender as pessoas e bens dos leais vassalos, escolhendo para os empregos militares os que deles se conhecessem capazes. VI. Que procurariam, quanto possível fosse, conservar o reino em paz, e que as tropas francesas fossem bem aquarteladas e assistidas de todo o necessário: evitando-se todo e qualquer insulto que se pudesse perpetrar, castigando-o quando acontecesse e conservando sempre a boa harmonia que ${ }^{\circ} e$ deve praticar com os exércitos das nações a que nos achamos unidos no continente» (Idem, ibidem, p. 221).

(31) Aperçu Nouveau sur les campagnes des français en Portugal, en 1807, 1808, 1809, 1810 e 1811, contenant des observations sur les écrits de M. C. Baron de Thiébault, Paris, 1818, pp. 54 e ss. 
ao invasor, nos seus dois momentos distintos. Se de Novembro a Junho pactuaram com as forças imperiais, a partir dessa altura, quando é conhecido em Lisboa e em todas as capitais europeias com representação diplomática portuguesa $O$ Manifesto e exposição* fundada por D. João VI (32), mudam de aliados e, em estreita colaboração com as massas populares, promovem a revolta contra o ocupante estrangeiro. A primeira aliança congeminada com espírito de traição evidencia uma ampla convergência táctica e coesão ideológica das classes dominantes. Como se escrevia na época «foram os franceses recebidos com os braços abertos mas os corações fechados» ( ${ }^{33}$ ). O colaboracionismo foi, pois, o meio mais eficaz de proteger e manter actuantes as instituições do «antigo regime». Ao acautelarem o regime e a ideologia que o justificava as classes históricas dominantes zelavam pela sua sobrevivência.

Resistir era, naquela circunstância, não só um acto de pouca coragem como até de imponderáveis consequências. Não deve portanto estranhar-se que a deputação a Baiona tivesse sido maioritariamente constituída por elementos da primeira nobreza do reino. Nela tomaram parte: o presidente do Conselho de Regência, o Marquês de Abrantes; o bispo de Coimbra, conde de Arganil e reitor da Universidade, D. Francisco de Lemos de Faria Pereira Coutinho; o bispo titular do Algarve e inquisidor geral, D. José Maria de Melo; o prior mor de Aviz D. José d'Almeida; o Camarista da rainha D. Maria I e deputado da Junta dos Três Estados, o Marquês de Penalva; o Embaixador em Paris, o Marquês de Marialva; o Marquês de Valença; o irmão do duque do Cadaval, D. Nuno Alvares Pereira de Melo; o Conde de Sabugal; o Visconde de Barbacena; D. Lourenço de Lima, antigo embaixador em França e nomeado por Junot presidente da deputação e os desembargadores Joaquim Alberto Jorge, e António Tomás da Silva Leitão, vereadores

(32) Vide Manifesto ou exposição fundada e justificativa do procedimento da corte portuguesa a respeito da França in S. J. da Luz Soriano, ob. cit., segunda ephoca, t. V, parte I, pp. 256-268. O eco das revoltas espanholas foi igualmente decisivo para esta viragem de comportamento político dos grupos dirigentes portugueses.

( ${ }^{33}$ ) Fr. Joaquim Soares, Compendio Historico dos acontecimentos mais celebres, motivados pela Revolução de França e principalmente desde a entrada dos francezes em Portugal até à segunda restauração deste, e gloriosa acclamação do Principe Regente o serenissimo senhor D. João VI: offe $e^{\wedge}$ ecido ao excelentíssimo e reverendissimo Senhor D. Antonio de S. José de Castro, Coimbra, 1808, p. 12. Por comodidade passaremos a identificar esta obra de 1808 de I e a de 1809, do mesmo autor e com o mesmo título mas de conteúdo diferente, de II. 
do Senado da Câmara de Lisboa (34). Premeditara Napoleão constituir um grupo de notáveis, onde se integrassem, em primeiro lugar, elementos da nobreza com relações de parentesco com a família reinante e outras figuras influentes do regime, com o objectivo de os afastar do país ${ }^{(35}$ ). No seu entendimento, como no de Junot, estas personalidades, fantasmaticamente erigidas com símbolos da monarquia absoluta, constituíam um perigo real para as pretensões hegemonistas da França imperial. O plano sigilosamente traçado, entre Lisboa e Paris, foi materializado com a colaboração dos governadores do reino. Cerca de 50 nomes estavam previstos mas apenas 14 foram oficialmente integrados na deputação representando três destes, instituições cimeiras como a própria Regência, a Universidade e a Inquisição. Mesmo antevendo os propósitos que animavam o imperador nem por isso se conformaram os titulares desta representação com a sua real situação de deportados. Exigiram que Napoleão respeitasse a sua condição de pares do reino e, como tal, legítimamente reclamaram, em Baiona, que «a dinastia de Bragança fosse reintegrada nos seus direitos» (36). Para lá do eco contrário que teve esta representação, nomeadamente pelo teor manifestamente artificial da acta final do encontro de 16 de Abril, que foi amplamente divulgada em todas as províncias do reino, afigura-se-nos que, mais uma vez, a máscara do colaboracionismo foi utilizada sem desprezo das convicções e aspirações dos que com ela se disfarçavam $\left({ }^{37}\right)$.

${ }^{(34)}$ Marquês de Resende, Breves Reflexões sobre um escripto recem-publicado em que se offende a chamada deputação portugueza que foi a França em 1808, offerecidas ao publico imparcial, Lisboa, 1871, p. 7.

(35) Disso nos dá conta o Diário de Junot publicado por Cristovam Ayres de Magalhães Sepúlveda, História orgânica e política do exército português. Provas, vol. XII, pp. 122, 124, 131-132, 146, 166, 174-75.

(36) Marquês de Resende, ob. cit., pp. 7-8. Bernardo António Serra de Mirabeau, «Exposição dirigida a Sua Alteza Real o Príncipe Regente por $D$. Francisco de Lemos....» O Instituto, Coimbra, n. ${ }^{\circ} 46$, 1899, pp. 145-156, 219-224, 272-275, 606-610, 726, 732, 778-784, 841-845, 912-916; e «D. Francisco de Lemos de Faria Pereira Coutinho. Esboço histórico-biográfico", O Instituto, Coimbra, n. ${ }^{\circ} 36,1889$, pp. 597-609, 669-678, 737-741; Luis A. Oliveira Ramos, «D. Francisco de Lemos e a Deputação a Baiona», in Estudos de História de Portugal - sees. $X V I-X X$, vol. II, Homenagem a A. H. de Oliveira Marques, Lisboa, 1983, pp. 275 e ss. Cf. Manuel Augusto Rodrigues, Biblioteca de D. Francisco de Lemos e da Mitra de Coimbra, Coimbra, 1984, pp. 278 e 287.

${ }^{37}$ ) Vide «Allocução da deputação portuguesa enviada por Junot a cumprimentar Napoleão e pela mesma deputação dirigida aos seus compatriotas", in S. J. da Luz Soriano, ob. cit., segunda ephoca, 
2.3. Mas existem outras manifestações, ainda mais concludentes, que atestam a fidelidade ideológica destes afrancesados a valores perfeitamente conservadores e até ultramontanos. $\mathrm{O}$ alto clero denuncia-os com a maior evidência.

Para assegurar «o respeito pela religião e seus ministros» (38) e garantir o reconhecimento da utilidade e importância da instituição eclesiástica, multiplicaram-se entre Dezembro de 1807 e Janeiro de 1808, pastorais de incitamento à paz e tranquilidade pública. Com o maior zelo D. Francisco de Mendonça fazia chegar a todas as dioceses, o seu apelo: «Não temais amados filhos, vivei seguros em vossas casas e fora delas; lembrai-vos que este exército é de sua magestade o imperador dos franceses e rei de Itália, Napoleão o Grande, que Deus tem destinado para amparar e proteger a religião e fazer a felicidade dos povos; vós o sabeis, o mundo todo o sabe; confiai com segurança inalterável neste homem prodigioso, desconhecido de todos os séculos. Ele derramará sobre nós as felicidades da paz se vós respeitardes as suas determinações, se vos amardes todos mutuamente, nacionais e estrangeiros, com fraterna caridade.... Tornamos finalmente a recomendar muito a todos os párocos nossos coadjutores, e mais clero deste patriarcado, e até lho pedimos pelas entranhas de Jesus Cristo, que concorram quanto lhes for possível para esta união em todas as ocasiões e lugares» $\left({ }^{39}\right)$.

O tom apologético e exaltado desta recomendação pode eventualmente esconder a secreta anuência da Igreja portuguesa à política de protecção do Papa Pio VII em relação à

t. V, Parte I, pp. 40 a 43. Sobre a divulgação que teve este texto veja-se António Ferrão, A l.a invasão Francesa. A invasão de Junot vista através dos documentos da Intendencia Geral da Polícia. 1807-1808, Coimbra, 1925, pp. 358 a 360, 367 a 370, 373; J. Acúrsio das Neves, acentua a ambiguidade do comportamento político dos membros da deputação a Baiona ao afirmar que essas «pessoas de consideração» foram "conduzidas pelos seus interesses, bem ou mal entendidos". (Ob. cit., t. II, p. 375). O sublinhado é nosso.

(38) Pastoral do Cardeal Patriarca de Lisboa, in S. J. da Luz Soriano, ob. cit., segunda ephoca, t. V, parte I, p. 11. Cf. Manuel Augusto Rodrigues, ob. cit., pp. 268-269. A este respeito confessava um clérigo «Os sacerdotes serviram sempre os conquistadores para melhor firmar a sua autoridade e o seu Império e, por isto, independentemente do seu carácter sagrado, eram por eles respeitados». Fr. Joaquim Soares, ob. cit., t. I, p. 15.

(39) Pastoral do Cardeal Patriarca de Lisboa, in S. J. da Luz Soriano, ob. cit., segunda ephoca, t. V, parte I, p. 11. 
França Imperial $\left.{ }^{40}\right)$. Contudo, depois da assinatura da concordata de 1801 e da sagração do imperador em 1804, Pio VII cai definitivamente em desgraça o que irá acarretar um progressivo agravamento de tensões entre Roma e Paris.

O facto de Napoleão ser ainda o signatário da concordata de 1801 e o detentor de um ceptro doado pelo sucessor de Pedro tornou, pelo menos, mais fácil o encargo apologético do alto clero português.

No discurso exaltado das pastorais, as categorias de pensamento ultramontano sobrepõem-se e validam-se por um processo meramente transferencial. Dito de outro modo, os objectos de referência são diferentes - note-se que a imagem da monarquia lusitana cauciona e surge como suporte oculto da visão de poder imperial napoleónico - mas os valores que se lhes atribuem permanecem os mesmos. Logo o imperador é tomado como símbolo da magestade de direito divino sobre quem recaía o peso de uma velha tradição de estrita fidelidade do Estado à Igreja. Paralelismo que autorizava a atribuição do título de sua Magestade Católica a Napoleão ( ${ }^{41}$ ). A legitimidade de uma autoridade «munida de sublimes poderes instituídos e ordenados por Deus» apontava para a exclusão de qualquer acto de resistência da comunidade $\left({ }^{42}\right)$. Daí que, segundo uma concepção romanista e ultramontana, expressamente afirmada, a não obediência ao poder napoleónico fosse sinónimo de «resistência à ordenação divina» $\left({ }^{43}\right)$.

Também só à luz de uma visão providencialista da história se pode compreender a alusão a Bonaparte como «homem prodigioso e desconhecido de todos os séculos», visão que entronca com outra imagem de inspiração histórica e que se funda na projecção do ideal de cruzada. Nesta perspectiva, as tropas religiosas de Napoleão configuram plenamente a ressurgência da mentalidade cruzadística de quinhentos. A persistência desta ideia-força no decurso da campanha restauracio-

C) António Ferrão, ob. cit., pp. CCXXVIII e CCXXXIX. Cf. Fortunato de Almeida, História da Igreja em Portugal, vol. 3, Barcelos, p. 278.

(41) «Este grande imperador, elevado sobre o trono dos seus triunfos tem unido a eles a gloria de fazer dominar a nossa sagrada religião nos seus estados. Sua Magestade Católica, ao mesmo tempo que no constante desempenho deste titulo tem feito a sua gloria imortal, igualmente nos dá também toda a segurança da permanencia do sagrado culto em que fomos educados». (Pastoral do Bispo do Porto, D. António de S. José de Castro, datada de 18 de Janeiro de 1808, transcrita por S. J. da Luz Soriano, ob. cit., segunda ephoca, t. V, parte I, p. 16).

(42) Idem, ibidem, p. 17.

(43) Idem, ibidem, p. 16. 


\section{Revoltas e Ideologias}

nista atesta, de forma modelar, o vigor e a importância do filão ideológico ultramontano dos inícios do século XIX (44).

\section{O Sebastianismo}

3.1.O aparente sentido de conivência que as autoridades portuguesas evidenciaram para com os «intrusos» e «ímpios» agentes do «tirano» Bonaparte causaram enorme desconcerto na mentalidade popular. Desconcerto corporizado em dois tipos de manifestações - na eflorescência do espírito messiânico e em acções espontâneas de repúdio e insurreição.

E de matriz sebástica o impulso que leva «uma grande parte dos carpinteiros e outros artistas involuntariamente ociosos, nutrindo-se de esperança, a cobrir continuadamente os altos de Sta. Catarina, Chagas, Buenos Aires e outros sítios elevados, lançando os olhos para a esquadra inglesa, contando os navios dela, parecendo-lhes a todo o instante que a viam entrar no Tejo, para resgatar Lisboa» ( $\left.{ }^{45}\right)$. Bloqueados pela esperança de uma intervenção exterior, impacientemente aguardavam, estes populares, o reencontro com a sua identidade mítica colectiva caldeada por um profundo sentido de fidelidade monárquica e sagrado respeito pela religião católica (46).

$\mathrm{O}$ retomar da origem fabulosa e fantástica do império português, assinalada pelo milagre de Ourique, alicerçava a esperança de um desfecho glorioso para a crise aberta em 1808 . A legenda de Ourique que servira igualmente de suporte à visão profética da Restauração de 1640, volta de novo a ser evocada e explorada. Um dos primeiros textos publicados pelos sebastianistas em 1808, foi extraído da Crónica de Cister, do alcobacense Bernardo de Brito, onde se fixa definitivamente essa versão lendária. Nas Victoriosas Promessas de Christo a

$C^{44)}$ Vide, infra.

(45) José Acúrsio das Neves, ob. czt., t. I, p. 269; cf. Carta de Hum Provinciano a hum seu amigo de Lisboa sobre a Guerra Sebástica, Lisboa, 1810, p. 7; e Camillo Luiz De Rossi, Diario dos acontecimentos de Lisboa por ocasião da entrada das tropas de Junot, Lisboa, 1942, pp. 31-32, 34-35, 38-39.

(46) A este respeito notava a Marquesa d'Alorna: «Un des préjugés de notre peuple est que le roi Sebastien doit encore venir; on le croit au contraire conservé par la Providence pour venir au secour du Portugal». Em seguida relata o ajuntamento popular ocorrido num bairro de Lisboa, ocasionado pelo aparecimento de dois ovos em que foram gravadas as inscrições V.S.R.P. (Viva Sebastião Rei de Portugal). Cf. António Ferrão, ob. cit., p. 261 e J. A. das Neves, ob. cit., t. II, p. 378. Este autor estimava que metade da população da cidade de Lisboa era sebastianista, Idem, ibidem. 
Portugal, na gloriosa aparição ao venerável D. Affonso Henriques em Campo de Ourique $\left({ }^{47}\right)$ reaviva-se a crença de que Cristo, ao fundar o reino, prescrevera, ao império luso, um destino sagrado e universal. Logo a restauração da independência em 1808, ao inscrever-se nesse ciclo providencial e divino, deveria ser obra de Deus e não dos homens. O sinal da empresa divina era dado por esta passagem do forjado juramento do primeiro monarca português: «Mando a meus descendentes, que para sempre sucederem que em honra da cruz e cinco chagas de Jesus Cristo tragam em seu escudo cinco escudos partidos em cruz, em cada uma serpente de Moisés, por ser figura de Cristo, e este seja o troféu da nossa geração. E se alguém intentar o contrário seja maldito do senhor e atormentado no inferno com Judas o traidor» $\left({ }^{48}\right)$. Ora a ordem de Junot de mandar suprimir, picar e cobrir com argamassa, as armas do reino «dadas por Deus» tornava inevitável o resgate divino do império cristianíssimo $\left({ }^{49}\right)$.

A obsessiva fixação a uma mundividência sacralizada, vivida e assumida profeticamente, põe ainda em destaque a similitude, explorada pelos sebastianistas e pelos integristas católicos em geral, do mouro na reconquista e do infiel na era

$\left.{ }^{47}\right)$ Victoriosas Promessas de Christo a Portugal, na gloriosa apparição ao venerável $D$. Affonso Henriques em Campo de Ourique, manifestadas no Auto de Juramento do mesmo rei, descuberto no cartorio de Alcobaça, no anno de 1596. Explicadas na lingua portugueza, e corroboradas pelos acontecimentos nelle preditos, e depois verificados. Em louvor de Sua Alteza Real o Principe Regente, Lisboa, 1808. A legenda de Ourique é constantemente evocada na literatura sebastianista desta época. Vejam-se entre outros: Notícia dos acontecimentos mais notáveis que fixarão as ephocas principaes da Monarquia Lusitana, expostos por hum quadro á vista de todos os portuguezes, para sua gloria, e rendimento de graças ao Todo-Poderoso, Lisboa, 1809; Manoel Joaquim Pereira de Figueiredo, Carta sobre o verdadeiro espirito do Sebastianismo, escripto a hum fidalgo desta Corte, Lisboa, 1810. O verdadeiro autor deste folheto é D. Francisco da Soledade. Cf. Brito Aranha, Nota acerca das Invasões Francezas em Portugal. Principalmente a que respeita à primeira invasão do comando de Junot, Lisboa 1909, p. 263; José Gonçalves Ramiro, Os Sebastianistas satisfeitos ou Discurso Apologético dirigido a Sua Alteza Real O Principe Regente N. S., Lisboa, 1810.

(48) Victoriosas Promessas...., pp. 11 e 12.

(40) Ibidem, p. 12. «Estas imprecações, e conjuras do Venerável D. Afonso como tão claramente as vemos executadas hoje nestes nossos dias! Pretendeu aleivosamente a França.... abolir estas Armas dadas por Deus e as fez vilmente riscar, e arrancar de quase todos os lugares onde se viam levantadas; mas apesar de tantos pérfidos, indignos, $e$ vis sequazes da infernal quadrilha, nada conseguiram, nada alcançaram, cederam ao braço Todo Poderoso, que pelejou, e venceu em nossas armas", (Ibidem, p. 12, nt. 2). 
da missionação colonial com os ímpios e irreligiosos agentes do «tirano satânico», Napoleão, no período das invasões.

Apesar de uns e outros partilharem de uma escala de valores comuns, isto é, de resolverem a angústia ideológica suscitada pelas invasões francesas, pelo recurso a categorias de pensamento sacralizadas e religiosas, o messianismo era apenas apanágio dos sebastianistas, tornando-se por isso, motivo de acesa polémica e factor de desagregação das hostes integristas católicas. Dele se demarcaram, também, os espíritos mais racionalistas.

No curto espaço de dois anos, entre 1808 e 1810, foram publicadas, sobre esta questão, cerca de trinta obras, muitas das quais anónimas $\left({ }^{30}\right)$. A polémica conhecida por «guerra sebástica» ( $\left.{ }^{51}\right)$ que se estende até 1823, envolve para cima de quarenta peças impressas, oito das quais da autoria do anti-liberal José Agostinho de Macedo, também aceso antagonista e animador da diatribe movida contra a «seita» $\left({ }^{52}\right)$.

Nos alvores desta recrudescência sebastianista estão dois opúsculos dados à estampa em 1808, um em forma de libelo de um membro da Academia Real das Ciências, eclesiástico e professor de filosofia no Seminário de Santarém, Pedro José de Figueiredo ( $\left.{ }^{53}\right)$, o outro em estilo apologético publicado anonimamente, as Victoriosas Promessas de Christo a Portugal. No

(50) Brito Aranha, ob. cit., pp. 261 a 269.

(51) Expressão que aparece num folheto anónimo publicado em Lisboa em 1810, e intitulado Carta de Hum Provinciano a hum seu amigo de Lisboa sobre a Guerra Sebástica....

$\left.C^{2}\right)$ São da autoria de José Agostinho de Macedo os seguintes opúsculos: Os Sebastianistas, primeira parte, Lisboa, 1810. Os Sebastianistas, segunda parte, Lisboa 1810; Inventário da refutação analytica feita por...., Lisboa, 1810; Justa defensa do livro intitulado Os Sebastianistas, resposta prévia a todas as satyras, $e$ invectivas, com que tem sido atacado o seu Autor...., Lisboa, 1810. A Senhora Maria ou nova impertinencia por...., Lisboa, 1810; Considerações christãs e políticas sobre a enormidade dos libellos infamatorios, Lisboa, 1810; Mais logica ou nova apologia da justa defensa do livro Os Sebastianistas, Lisboa, 1810; O Sebastianista desenganado à sua custa. Comedia composta por...., Lisboa, 1823.

(M) Carta em resposta de certo amigo da cidade de Lisboa a outro de villa de Santarém, em que se lançam os fundamentos sobre a verdade, ou incerteza da morte d'El-Rei D. Sebastião, Lisboa, 1808. Opúsculo que não conseguimos encontrar. A sua indicação é feita por Brito Aranha, ob. cit., p. 262. Cf. José Alberto Veiga, Fonction et signification sociologique du messianisme sebastianiste dans la société portugaise. Thèse de Doctorat sous la direction de Raymond Cantel, vol. 3. Paris, Université de Paris III a Sorbonne, 1979, p. 658. (Exemplar mimeografado). 
desenrolar da polémica surgem ainda três versões das Trovas de Bandarra, duas das quais impressas em Londres em 1809 e 1810. A primeira, supostamente editada em Barcelona, apoia-se no texto publicado em Nantes em 1644 e agrega dois corpos de coplas acrescentados no século XVIII ( $\left.{ }^{54}\right)$. A segunda versão, de 1810, atribuída ao dominicado José Leonardo da Silva consiste numa longa paráfrase ao $3 .^{\circ}$ corpo das Trovas (55). Este particularmente explorado porque melhor prenunciava as infaustas invasões. Eis alguns desses vaticínios:

\author{
Ergue-se a Águia Imperial \\ Com seus filhos ao rabo \\ E com as unhas no cabo \\ Faz o ninho em Portugal.
}

Põe um - A - pernas acima

Tira-lhe a risca do meio

E por detrás lha arrima

Saberás quem te nomeio.

E o comentador acrescentava: «Nada é tão natural como o que houvesse de ser revelado a Bandarra, o nome de Napoleão assim como, the havia sido revelado o levantamento dos portugueses contra as suas tropas e o ano em que teria efeito e a vinda e entrada da sua Águia Imperial.... Pelo que ainda que absolutamente falando aquele - N - possa denotar qualquer outro, ...não pode aquela letra denotar a outro, que não seja Napoleão» ( $\left.{ }^{56}\right)$.

$\mathrm{O}$ relevo dado aos factos premonitórios que anunciavam a vinda do encoberto, permite-nos vislumbrar a imagem construída pelos sebastianistas da sociedade portuguesa. A convicção de decadência absoluta do império — «a grandeza melhor mal governada. / A república em fím despedaçada» justificava numa perspectiva providencial, a acção malévola de um heresiarca, de um anticristo Napoleão que "promulgando infernal e dogma informe; / aos mais potentes príncipes do mundo» alertava o povo «para que de seus vícios se reformasse» $\left({ }^{57}\right) .{ }^{*}$ III,

(M) Trovas de Bandarra, Barcelona, 1809.

(55) Bandarra Descuberto nas suas Trovas. Colleção de Profecias mais notáveis, respeita a felicidade de Portugal, e Cahida dos maiores dos maiores Imperios do mundo, Londres, 1810. Cf. I. Francisco da Silva e P. V. Brito Aranha, Diccionario Bibliographie o Portuguez, vol.

III, p. 154 e vol. IV, p. 417.

(w) Idem, pp. 20 e 21.

(57) Idem, p. 26. 
Aponta-se para uma remissão colectiva da sociedade por que os grandes males que sobre ela se abatiam eram de natureza religiosa e moral. Das ruínas espirituais de «eleita Lusitânia», «Império do Universo Sumo e Grande», brotaria redivivo, o prodigioso monarca que sujeitaria à lei de Cristo «a do gentio, a do mouro, a do otomano e todos os incensários de Lucifer» ${ }^{(58)}$. O regresso do rei encoberto valia como acto purificador da sociedade e alimentava, numa perspectiva teleológica, a esperança de um hegemonismo espiritual à escala mundial.

3.2. A aceitação crescente destas ideias suscitou juízos irónicos, críticas cuidadas e até increpações violentas. $\mathrm{O}$ número dos incrédulos em relação ao sebastianismo não era de modo nenhum insignificante, apesar de José Agostinho de Macedo considerar em contínuo crescimento «a importuna seita». Logo após a expulsão da segunda vaga invasora, lamentava o mesmo panfletário: «Já não vemos os franceses, mas ainda vemos, suportamos e aturamos os sebastianistas, atroz flagelo, causa contínua da nossa infâmia» $\left({ }^{59}\right)$.

Um outro autor igualmente empenhado em anatematizar o carácter fabuloso dos prognósticos sebastianistas, exclamava: «Quem diria que estes papéis [profecias] depois de terem vivido por tantos anos homiciados com ar de réus, aparecendo só às furtadelas, e como envergonhados, haviam pela primeira vez de se apresentar ao público em toda a pompa e aparato no séc. XIX» e rematava «Faltava mais esta ao nosso século para ser o século das inconsequências» $\left({ }^{60}\right)$. Apreciação que traduz virtualmente a ideia de que a crença na razão se não coadunava com estas manifestações de fanatismo e credulidade. A mesma perspectiva racionalista e crítica enforma um relato irónico e fantástico da ilha encoberta que servia de morada à faustosa corte de D. Sebastião. Este opúsculo insere-se na polémica suscitada pela obra de José Agostinho de Macedo, Os Sebastianistas. Contra a forma judicatoria e insultuosa da impugnação de Macedo, o autor da Carta de Hum Guarda-Roupa d!el Rei D. Sebastião ( $\left.{ }^{61}\right)$ prefere

(58) Idem, p. 28.

$\left.C^{9}\right)$ José Agostinho de Macedo, Os Sebastianistas, I, p. 6.

${ }^{60}$ Exame e juizo critico sobre o papel intitulado Anti-Sebastianismo, annunciado na Gazeta de Lisboa de 28 de Setembro do presente anno. Lisboa, 1809 , pp. 35 e 36.

(61) Carta de hum guarda roupa d'El-Rei D. Sebastião a um Amigo seu nesta Corte, em que, depois de humas breves reflexões sobre o folheto intitulado Os Sebastianistas, lhe dá huma noticia circunstanciada da Ilha Encuberta e da existência daquelle soberano. 
demonstrar a nulidade das profecias sebastianistas, remetendo para o plano do imaginário a existência do monarca desejado, D. Sebastião. Operação que implicando uma construção simbólica tipicamente utópica se não apresenta no seu resultado final como utopia, mas antes como uma contra-profecia. Se pela sua intenção é um folheto vulgar já pelos processos a que recorre é dos mais interessantes e ricos da longa série publicada na época. Se não vejamos: num espaço sem existência real, mas construído à semelhança do universo físico pela lei da gravidade, permanecia na sua aparência intemporal o augusto soberano «sem a menor alteração tanto no seu temperamento, como na mocidade, beleza e feições» ${ }^{(62}$ ). O seu atributo, o de encoberto advinha agora da natureza da ilha que habitava, espaço geometrizado concebido em forma de círculo no centro do qual se inscrevia uma sumptuosa fortificação hexagonal (63) - riqueza urbanística, que era sinal de uma «abundantíssima produção» de géneros e outros bens. A indústria da ilha encoberta concentrava-se numa oficina subterrânea - aqui é manifesta a inspiração da Casa de Salomão da Nova Atlântida de F. Bacon - onde trabalhavam continuadamente 30 homens artificiais, uns de bronze outros de mármore. Estes autómatos executavam «tudo o que a arte, e indústria dos homens animados tem imaginado de mais raro» $\left({ }^{64}\right)$.

Finalmente sugere-se um idílio fabuloso entre D. Sebastião e uma soberba estátua, que, ao consumar-se, assinalaria o lendário e triunfante regresso do jovem rei à sede natural do

Tudo em estilo-jocoserio unico proprio de semelhante assumpto. Dada a luz e vendida aos curiosos por $F$. de $P$. J. Tem relação com este folheto esta obra publicada anonimamente em Lisboa em 1815: Carta em resposta a hum Amigo, na qual se dá notícia da ilha Antilia, ou de S. Borondon, ou Santa Cruz, vulgarmente denominada a Ilha Encuberta.

(62) Carta de hum guarda-roupa d'El-Rei D. Sebastião...., p. 9.

(e3) «Esta ilha, cuja forma é redonda terá 4000 passos de diâmetro, e só difere das outras em estar por toda a parte cercada de água.... Em toda a circunferência da ilha, e a pequena distância da praia há de dez em dez passos outras colunas, sustentando cada uma delas sua estatua, e cada uma destas de diversas matéria. Umas são de safiras, outras de rubis, outras de esmeraldas, etc., todas em acção melancólica, chorando finíssimas pérolas.

No interior da ilha ha um hexágono fortificado, segundo as melhores máximas, cujas muralhas são de alvíssimo jaspe, os parapeitos de diamante, os fossos de coral, e a esplanada de topázios.... No centro do hexágono há uma torre redonda em forma de cidadela, com 35 passos de diâmetro, e 50 de altura, feita de um só brilhante, cujo interior serve de residência ordinaria ao nosso Augusto soberano o Senhor Rei D. Sebastião» (Idem, p. 9).

(M) Idem, p. 10. 


\section{Revoltas e Ideologias}

seu Império. Previsão totalmente improvável porque condicionada à natureza inconclusiva de uma relação amorosa entre um ser humano, de origem divina, e um autómato de criação humana.

Não foi, em todo o caso, com argumentos racionalistas e laicizantes que o mais vibrante opositor dos sebastianistas, José Agostinho de Macedo intentou desbaratar «o maior delírio da história universal» $\left({ }^{65}\right)$. Nos dois volumes de Os Sebastianistas a tradição lendária do messianismo sebástico é examinada com a finalidade de se demonstrar a inautenticidade canónica da sua inspiração. Conclusão que tendia a sancionar a acção do Santo Ofício na repressão dos falsos profetas e seus seguidores. Depois de reduzir a esperança sebastianista a proporções absurdas, Agostinho de Macedo procede à impugnação do comportamento dos prosélitos dessa «crença pueril» (66). A este nível põe em destaque a passividade e indolência destes, que acusa de traidores, dada a necessidade de uma aberta e activa luta contra os verdadeiros inimigos da pátria, os mações e os liberais.

Como argumento polémico da visão de Macedo ressalta a conivência activa ou passiva, deliberada ou não, entre sebastianistas e pedreiros livres $\left({ }^{67}\right)$. Espectralmente, é a aliança contra-natura da nação com o invasor, mediada pela maçonaria que funciona no seu discurso maniqueísta como demonstração do perigo que os sebastianistas representavam. Pela passividade e indiferença com que aguardavam a vinda do rei encoberto, promoviam o livre curso e o avanço temível dos princípios da revolução francesa $\left({ }^{68}\right)$.

(65) José Agostinho de Macedo, Os Sebastianistas, II, p. 66.

(66) Idem, ibidem, I, p. 7.

${ }^{(67)}$ Sobre a polémica, em torno da questão sebástica, que opôs J. A. de Macedo a João Bernardo da Rocha Loureiro e Pato de Moniz, veja-se Georges Boisvert, Un Pionnier da la propagande liberal au Portugal: João Bernardo da Rocha Loureiro (1778-1853), Paris, 1982, pp. 100-102. Cf. José Alberto Veiga, ob. e vol. cits., pp. 665-867.

(68) Sob o influxo das máximas barruelianas a visão orgânica e funcional da maçonaria configura uma realidade de facto inexistente na vida política de então - o partido. A maçonaria, sempre aparentada a uma organização de tipo cripto-partidário, descentra, no entendimento histórico de Macedo e dos ideólogos do regime, a problemática do desfasamento dos processos revolucionários em curso em França e Portugal. A obra do Abade Barruel que J. A. de Macedo traduziu muito contribuiu para que esta concepção se impusesse. Vide José Agostinho de Macedo, O segredo revelado, ou manifestação do Systema dos Pedreiros-Livres, e Iluminados, e a sua influência na fatal Revolução Franceza: obra extrahida das Memorias para a Historia do Jacobismo do Abade Barruel, e publicada em portuguez para confusão dos impios, e cautela dos verdadeiros amigos da religião e da Pátria...., parte I (Lisboa, 1809); II (idem, 1810); III (idem); IV 


\section{Revoltas e Revoluções}

Entretanto, a «guerra sebástica» ia assumindo, na opinião de um interveniente na polémica, proporções preocupantes quase fazendo esquecer a existência de uma outra e mais decisiva frente de combate. $\mathrm{O}$ autor do Exame, e Juízo Crítico sobre o papel intitulado Anti-Sebastianismo relatava assim o estado da contenda: "Nunca em Portugal se deu tanto exercício às penas, como nesta calamitosa época, em que só se deveria dar exercício às armas. Todos aspiram à glória de escritores quando deviam aspirar à de guerreiros; e como se o tinteiro fosse fuzil, a pena espada, a areia pólvora e a tinta balas; com tinteiro, penas, areia e tinta nos propomos vencer inimigos que nos acometem com fuzil, espada, pólvora e bala. Se o conseguirmos teremos a glória de haver descoberto um grande segredo» $\left({ }^{69}\right)$.

Deliberadamente exagerado este juízo não deve fazer-nos esquecer as ruidosas e contínuas manifestações de descontentamento das classes populares.

\section{O calendário religioso e a cronologia das revoltas de 1808}

4.1. Logo em Dezembro de 1807, quando, com grande aparato militar, foi pela primeira vez hasteada a bandeira tricolor francesa no Castelo de S. Jorge em Lisboa, os habitantes das zonas circunvizinhas reagiram com «um triste sussurro» $\left({ }^{70}\right)$. Nesse mesmo dia [13 de Dezembro] à noite sucederam-se desacatos e confrontações no Rossio, Rua do Ouro, e Terreiro do Paço, desordens que na opinião de um influente contemporâneo não passavam de «tumultos da gentalha sem plano premeditado» $\left({ }^{71}\right)$.

(idem); V (idem, 1811) e VI (idem, 1812). Inocencio Francisco da Silva põe em dúvida que toda a tradução pertença a Agostinho de Macedo (ob. cit., t. IV, p. 209).

(69) Exame $e$ juízo crítico sobre o papel intitulado Anti-Sebastianismo, annunciado na Gazeta de Lisboa de 28 de Setembro do presente anno, Lisboa, 1809, p. 18.

(70) José Acúrsio das Neves, ob. cit., t. II, p. 271.

(n) Ricardo Raimundo Nogueira, Apontamentos in C. A. de Magalhães Sepúlveda, ob. cit., vol. $X$, p. 78. No ofício do intendente geral da Polícia aos governadores do reino, de 14 de Dezembro, fala-se «da desordem que se suscitou no Terreiro do Paço e que por efeito de uma impulsão toda mecânica se estendeu a outros diferentes sítios da capital», sendo tudo obra da «plebe desatinada» in António Ferrão, ob. cit., p. 35. Estes desacatos motivaram a proclamação de Junot de 15 de Dezembro que proibia todo o tipo de ajuntamentos e anunciava a criação de uma comissão militar para sentenciar os individuos suspeitos de envolvimento. Vide Supl. à Gazeta de Lisboa de 18 de De- 
As rixas entre o povo da capital e os soldados franceses eram constantes, tinham normalmente como palco os bairros pobres, onde proliferavam tabernas, botequins, e casas de meretrizes. São frequentes as referências, nos relatos e participações diárias da Intendência Geral da Polícia, de ajuntamentos e desacatos, especialmente nos Bairros de Mocambo, Remolares, Cais do Sodré, Alfama, Mouraria, Alcântara e Bairro Alto. Por exemplo, a 8 de Janeiro, na rua dos Galegos, (Bairro Alto) foram algumas meretrizes acusadas de provocarem desordens $\left({ }^{72}\right)$. Num ofício de 15 de Janeiro falava-se de «uma bulha de paus», na calçada de Santo André (Bairro da Mouraria ( $\left.{ }^{73}\right)$. No dia seguinte, o Intendente da Polícia informa a Regência que na rua dos Mastros (Bairro da Mouraria) tinha havido um grande ajuntamento de povo (74). A 20 participate «uma desordem na Travessa de S. Caetano (Bairro do Mocambo)» $\left({ }^{75}\right)$.

Em Março já os ânimos andavam mais agitados como se infere por este relato do dia 8: «Ontem, pelas 5 horas da tarde, houve em diferentes ruas do Bairro do Mocambo um grande tumulto causado pelos soldados da região (sic) do Midi, aquartelada em S. Bento. O lugar principal dele foi a Travessa do Pasteleiro, onde concorreram muitos dos ditos soldados com terçados nús, dando em quem passava» $\left({ }^{76}\right)$.

Observam-se também nestes locais da cidade manifestações de uma agressividade mal controlada e indevidamente dirigida. Disso são prova as frequentes desavenças entre os seus habitantes, desacatos que por vezes culminavam em casos

zembro de 1807. A medida exasperou o ânimo da população e, dois dias depois, por ocasião do aniversário da soberana, D. Maria I, Lisboa converteu-se em palco de rixas acesas entre populares e militares. J. Acúrsio das Neves não nos dá específicamente conta dessas hostilidades, apenas regista «o dia 17 de Dezembro foi marcado pelo grande número de tropas francesas que rondavam as ruas da capital» (ibidem, p. 282). A proclamação de Junot de 18 de Dezembro, inserta no Supl. à Gazeta de Lisboa, relativa aos acontecimentos do dia anterior, não nos deixa margens para dúvidas sobre a existência dos confrontos de 17 de Dezembro. Cf. Ofício do intendente geral da Polícia, Lucas Seabra da Silva, a Junot de 18 de Dezembro de 1807 in António Ferrão, ob. cit., pp. 56-57. Sobre os tumultos de Lisboa da Primavera de 1808 e de Caldas da Rainha, veja-se S. J. da Luz Soriano, ob. cit., segunda ephoca, t. I, pp. 194-197.

(72) António Ferrão, ob. cit., p. 127.

(") Idem, ibidem, p. 150.

(") Idem, ibidem, p. 152.

(75) Idem, ibidem, p. 160.

o Idem, ibidem, pp. 255 e 256. 


\section{Revoltas e Revoluções}

de homicídio. A indigência e a fome ocasionavam igualmente numerosas descrições de arrombamentos e furtos $\left({ }^{77}\right)$.

Os aboletamentos em massa das tropas francesas e espanholas em conventos e colégios de ordens religiosas - sinal de manifesto ultraje à dignidade dessas casas - associado à interdição do toque de sinos e à suspensão das tradicionais práticas litúrgicas do Natal, rituais de amplo significado para a mentalidade popular, foram factores que desempenharam, seguramente, um papel importante para o agravamento das tensões nos meses de Janeiro e Fevereiro $\left({ }^{78}\right)$.

É pelo menos sintomático que os afrontamentos mais graves com os ocupantes estrangeiros surjam quase sempre a propósito de ocorrências religiosas de certa solenidade, como cortejos e procissões, a tal ponto que, por um decreto de 7 de Janeiro, Junot obrigava todos os párocos, que saíssem das suas igrejas com o Santíssimo Sacramento, a abençoarem os soldados franceses $\left({ }^{79}\right)$.

$\mathrm{O}$ receio de desenvolvimentos revolucionários em ocasião de grande concentração de devotos, acarretou, posteriormente, a proibição dos tradicionais jogos do Entrudo $\left({ }^{\circ}\right)$. E não era só na capital que se temiam estes momentos como se verifica pela informação lavrada pouco antes da Quaresma pelo corregedor da Comarca do Ribatejo. Nesse documento expunham-se os inconvenientes que podiam advir da realização das procissões de Alhandra, Alverca e Vila Franca, «por concorrer a elas grande número de campinos e homens das lezírias, e por ser possível nessas ocasiões passarem tropas francesas, com risco de suscitarem desordens e rixas de funestas consequências» $\left({ }^{81}\right)$.

(") Idem, ibidem, pp. 88-90, 93, 106, 163, 176, 265-266.

(78) Vejam-se as ordens do Cardeal Patriarca de 19 e 23 de Dezembro (J. Acúrsio das Neves, ob. cit., t. I, p. 28). Atente-se ao comentário do Observador Portuguez Historico e Político: «Nesse grande dia tudo foi tristeza e contemplação; não houve missa do Natal (ou do Galo); os sinos nem à noite nem de madrugada tocaram; as igrejas fechadas até sair o sol e finalmente tudo foi uma mudança sem termos, sem política, sem Religião. E bem certo que as circunstâncias quase sempre decidem a sorte dos homens, e principalmente na época presente em que um tirano imperador que tudo deve à sua astúcia e diabólica maxima, perfídia e fortuna das armas», p. 161, cit. por A. Ferrão, ob. cit., p. 82. Vale a pena notar também ^que Daniel Rodrigues da Costa inicia o seu jocoso folheto Protecção à Franceza com os seguintes versos: «Que vem a ser ter entrada / Dias antes do Natal / (Tropa estranha em Portugal....», Lisboa, 1809, p. 1.

$\left.{ }^{75>}\right)$ Cf. António Ferrão, ob. cit., p. 126. Veja-se ainda os litígios mencionados nas pp. 88 e 110 . ob. cit., p. 237

$\left.{ }^{80}\right)$ Edital de 25 de Fevereiro de 1808. Cf. António Ferrão,

(81) Idem, ibidem, pp. 238-239. 
De facto, a oportunidade das revoltas à escala nacional foi profundamente marcada pelas celebrações festivas da Igreja nos meses de Junho e Julho. Dito de outro modo, a cronologia das revoltas de 1808 acompanha de perto e coincide em muitos casos, com certas datas especiais do calendário litúrgico. $\mathrm{O}$ movimento restauracionista que haveria de contaminar todas as províncias do Norte e até o Algarve inicia-se no Porto a 6 de Junho, quando se celebrava a festa das justiças na igreja de

S. Domingos ( ${ }^{82}$ ). No dia seguinte, os chefes dos insurgentes «invocaram o auxílio da Virgem Santíssima do Rosário, padroeira da fortaleza de S. João da Foz e dedicaram-lhe aquele dia em nome de S. A. R., com o voto de uma solene festividade anual para perpetuar a memória de uma tão justa empresa» ( $\left.{ }^{83}\right)$. Em Chaves «foi a festa do Espírito Santo que produziu os primeiros sintomas da Revolução» $\left({ }^{84}\right.$ *). A chama da insurreição torna a lavrar no Porto a 18 de Junho. Os primeiros indícios do movimento manifestam-se no dia do Corpo de Deus (16 de Junho). Nesse dia «cresceu a fermentação e dispozeram-se todos para calcar o seu jugo logo que se pronunciasse o primeiro viva, que não tardou muito. Para isto concorreu muito uma proclamação do desembargador José Feliciano da Rocha Gameiro que apareceu no dia de Corpo de Deus... nesse dia esteve para se fazer a Restauração» ( $\left.{ }^{80}\right)$. Em Olhão, no dia de Santo António, o escrivão do compromisso marítimo resolveu pôr a descoberto as reais quinas que encimavam a igreja matriz, talvez para dar maior solenidade aos festejos e concitar «o geral contentamento dos pescadores que a terem quem os dirigisse teriam usado armas como fizeram três dias depois» ( $\left.{ }^{86}\right)$. O «entusiasmo e o furor» com que os olhanenses saudaram Santo An-

C82) J. Acúrsio das Neves, ob. cit., t. III, p. 44.

$\left.\mathrm{t}^{83}\right)$ Idem, ibidem, p. 49.

O Idem, ibidem, pp. 61-62. O mesmo autor reforça a possibilidade de um exacerbamento do espírito sedicioso nessa ocasião, com estas palavras: díodos sabem o modo singular com que os povos de Portugal celebram a festividade do Espírito Santo; festividade de uma grandíssima devoção para com estes povos, mas em que o profano se tem misturado com o sagrado» (p. 61). Sobre a eclosão das revoltas em (Trás-os-Montes vide: Memorias da Villa de Chaves na gloriosa Revolução contra a perfidia do tirano da Europa, Lisboa, 1809; Relação fiel e exacta do principio da Revolução de Bragança e consequentemente de Portugal, s.l., s.d., Sepulvçda Patenteado, ou, Voz Publica ou solemne, depositada em Documentos Authenticos, que devem servir para resolver a questão: Quem foi o primeiro chefe, e proclamador da Revolução Transmontana em 1808, Londres, 1813.

$\left(85>{ }_{\text {Frei }} \mathbf{j}_{0 \mathrm{a}} q_{\mathrm{U}} \mathrm{i}_{\mathrm{m}}\right.$ Soares, ob. cit., I, p. 26. Cf. Acúrsio das

Neves, ob. cit., t. III, p. 86.

(M) Joaquim Filipe de Landerset, Breve Noticia da Feliz Restauraçấo do Reino do Algarve e mais sucessos até ao fim da marcha 
tónio depressa se converteu numa verdadeira insurreição que irrompeu exactamente quando se celebrava a antiga festa e procissão do Corpus Christi. De Olhão partiu assim o movimento libertador que atingiu todo o Algarve e algumas localidades alentejanas $\left({ }^{87}\right)$.

Em Lisboa o dia de Corpo de Deus foi também «aziago» para os franceses. A procissão saiu para a rua, sem a figura do padroeiro, S. Jorge, «o que era já um grande desgosto para o povo» $\left({ }^{88}\right)$. O reboliço inicial depressa se converteu em motim com «uma voz, que se levantou do meio do maior tumulto» anunciando um desembarque inglês na foz do Tejo $\left({ }^{89}\right)$.

\section{Génese e ritmos das revoltas restauracionistas}

5.1. Só como já notámos, em Junho, e com o alastramento da sublevação espanhola, a insurreição adquire entre nós uma dimensão nacional. Os dois movimentos insurreccionáis peninsulares evoluem mimeticamente cruzam-se em alguns aspectos, para, por fim, se distanciarem, radicalmente, na concreção político-institucional dos seus postulados originários $\left({ }^{90}\right)$. Em Portugal o movimento foi de superfície. O quadro das suas dominâncias sociais e ideológicas, atesta ainda a vitalidade da triangulação aristocracia rural-clero-campesinato, típica de uma sociedade de «antigo regime». A aliança histórica desses grupos, ruborecida pela ideologia ultramontana, desembocou num simples movimento de restauração. Em Espanha, como se sabe, a sublevação liderada ideológica e militarmente pelas Juntas Provinciais converteu-se em dinâmica revolucionária atingindo com a Constituição de Cádis de 1812, o seu pleno sentido. Da intercepção destes dois movimentos peninsulares distintos ressaltamos a comunicação das Juntas de Sevilha e da Galiza *S.

do Exercito do Sul em auxílio da capital, por J. F. L. Official do mesmo Exercito, Lisboa, 1809, pp. 7 e 8. Cf. J. Acúrsio das Neves, ob. cit., t. III, p. 139 .

i87) Vide Alberto Iria, A Invasão de Junot no Algarve. Subsídios para a História da Guerra Peninsular - 1808-1814, Lisboa, 1941, pp. 34-36.

O J. Acúrsio das Neves, ob. cit., t. III, pp. 132-133.

(8\#) Fr. Joaquim Soares, ob. cit., II, p. 27. Na sequência destes acontecimentos proibiram-se as tradicionais fogueiras de S. João, S. Pedro e S. Marçal.

$\mathrm{O}$ J.-R. Aymes, La Guerre d'indépendance espagnole (1808-1814), Paris, 1973. Albert Silbert, «Le Portugal et l'étranger pendant la periode Révolutionnaire et Napoléonienne» in Actes du Colloque Patriotisme et Nationalisme en Europe de l'époque de la Révolution Française et de Napoléon, XIII Congrès international de Sciences historiques (Moscou, 19 août, 1970), Paris, 1973. 


\section{Revoltas e Ideologias}

com algumas congéneres instituições portuguesas, a colaboração activa de contingentes militares espanhóis de algumas praças, cidades e vilas próximas da fronteira ( ${ }^{91}$ ) e a influência exercida pela imprensa e pela literatura panfletária espanhola ( $\left.{ }^{92}\right)$.

A revolta contra o ocupante e seus colaboracionistas estalou com ampla participação das massas camponesas e urbanas que, por toda a parte, do Minho ao Algarve, em acções descoordenadas de banditismo político, só aparentemente ameaçavam perigar a hierarquia da ordem social estabelecida.

Quando em Junho o contingente espanhol chefiado pelo general Ballesta abandona as hostes do exército associado no Porto, com a intenção expressa de retornar a Espanha e aí engrossar o movimento restauracionista, o povo do norte «está pronto para iniciar o levantamento» $\left({ }^{93}\right)$.

Em todo o caso, as gentes do Porto não tiveram participação activa no acto proclamador da restauração, em 6 de Junho. Tratou-se antes de um golpe conspirativo movido pelo general espanhol Ballesta, e no qual tomaram parte elementos do Senado da Câmara, da Relação e do Governo das armas da cidade. Desta representação, nada pacífica em termos de opinião, obteve Ballesta, antes da sua retirada, a garantia do restabelecimento do governo legítimo na capital nortenha. Estava pois criada uma situação perfeitamente singular. $\mathrm{O}$ mesmo contingente militar que colaborara na ocupação militar do norte desencadeava, num acto de pesadas consequências, a revolta do país contra o exército napoleónico.

O malogro desta primeira tentativa de aclamacão do governo legítimo, ficou a dever-se à acção do brigadeiro Luís de Oliveira Osório e de alguns magistrados, nomeadamente do corregedor José Teixeira de Sousa e do desembargador João Mateus da Silva Ferrão que resistiram a abdicar da submissão ao governo de Lisboa. Mas nem por isso o número dos conspiradores que afluíam à casa do desembargador Joaquim Rodrigues Botelho deixava de crescer, dele fazendo parte muitos religiosos da ordem de $\mathrm{S}$. Domingos e $\mathrm{S}$. Jerónimo. Enquanto isso, «rasgavam-se editais e crescia a fermentação» entre 0 povo da cidade. Recusando obediência às autoridades constituídas, os populares acabaram por encontrar os seus próprios

O Vide infra.

$\left.C^{2}\right)$ Nomo Daupias d'Alcochete, Les pamphlets portugais anti-napoléoniens, Paris, 1978; Georges Boisvert, oh. cit.f pp. 315-321 e 394-401; José Amaro Albuquerque de Oliveira, A ideologia planfetária durante as Invasões Francesas, Lisboa, 1963, (tese de licenciatura dactilografada).

${ }^{(93)}$ José Acúrsio das Neves, ob. cit. 


\section{Revoltas e Revoluções}

chefes. Sob o influxo da dinâmica das Juntas Provinciais do país vizinho, os revoltosos dirigidos pelo capitão de artilharia João Manuel Mariz Sarmento e pelo oficial de engenharia Luís Cândido Pinheiro institucionalizam o movimento e entregam a presidência da Junta ao carismático bispo do Porto, D. António de S. José e Castro. A Junta Provincial do Supremo Governo do Reino, interpretando esse patriotismo espontâneo miticamente sedimentado em torno da realeza e do altar, dirige a campanha anti-francesa e avança para a formulação de um incipiente programa político que aponta inegavelmente para a instauração de um regime, em que, «no exercício da sua constituição o monarca e o povo concorram simultaneamente para o mesmo fim, sendo reciprocamente interessados no equilíbrio dos seus direitos» $\left({ }^{94}\right)$. A vinculação a um modelo político de tipo parlamentar provavelmente de inspiração britânica é apenas insinuada, não decorre de uma fundamentação ideológica rigorosa. A esta proclamação, ditada pela ala militar da Junta, se opôs energicamente a corrente contrária chefiada pelo bispo e secundada pelos elementos mais conservadores do clero e da magistratura.

A revolta que chegou a transpor os limites da ordem estabelecida, projectando-se em proposta de viragem política de tipo liberal, foi de novo conduzida, sob pressão do bispo ao statu quo ante $\left({ }^{95}\right)$.

O 6 de Junho no Porto foi como uma «faísca que soprada pelo vento da revolta» ( $\left.{ }^{96}\right)$ logo se propagou a Bragança, Chaves, Miranda, Vila Real, Moncorvo, Ruivães, Melgaço, Guimarães, Braga, Viana do Castelo, Barcelos e outras localidades. Como exclamava Acúrsio das Neves rebentara «o vulcão de que não houve forças que pudessem suspender a torrente» $\left({ }^{97}\right)$.

A rápida propagação da revolta nas províncias do Minho e Trás-os-Montes está relacionada com uma insuficiente cobertura militar por parte das tropas invasoras e com a manifesta

(w) In José Liberato Freire de Carvalho, O Campeão Portuguez, de 16 de Julho de 1819, vol. I, pp. 63-67.

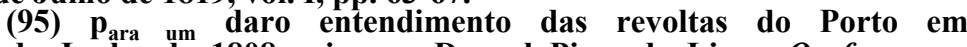
6 e 8 de Junho de 1808 vejam-se Durval Pires de Lima, Os franceses no Porto (1807-1808), diário de uma testemunha presencial, Porto, 1949; Pedro Vitorino, O Grito da Independência de 1808, Coimbra, 1928; Fr. Joaquim Soares, ob. cit., t. I e II; Raimundo José Pinheiro Furtado, Cópia de dois documentos relativos à nossa restauração principiada em 1808 na cidade do Porto, Lisboa, 1821 e J. Acúrsio das Neves, ob. cit. t. III, capítulos VI, VII, XII.

O Dietário do Mosteiro de $S$. Bento, in C. A. de Magalhães

Sepúlveda, ob. cit., vol. X, p. 318.

(9T) J. Acúrsio das Neves, ob. cit., t. II, p. 61. 
resistência revelada pelas autoridades locais em aplicarem os decretos e editais relativos ao desarmamento e licenciamento de tropas portuguesas.

Ao aparecerem os primeiros indícios da revolta na Galiza começara em Bragança «a cogitar-se a insurreição contra os franceses» (98). O povo andava «impaciente», havia uma geral perturbação e corriam rumores de que sigilosamente se preparava um levantamento ("). A mesma desconfiança e expectativa se registava em Braga, Chaves, Vila Real e Melgaço. De facto numa observação de superfície sobre a eclosão dos levantamentos no norte, afigura-se-nos manifesto o esforço revelado pelos senhores locais para encabeçar esses movimentos revoltosos. Pretendiam, em suma, materializar a crescente onda de indignação que se acoitava no espírito de todos sem atropelo de interesses e estatutos sociais secularmente admitidos.

No plano de sublevação de Bragança estavam implicados: o abade de Carrazedo, Manuel António de Sousa Madureira Cime, governador do bispado, o general Manuel Jorge Gomes de Sepúlveda e alguns militares de patente.

Em Chaves, porque o mesmo mal-estar se fazia sentir, um grupo de notáveis da terra, dirigido pelo administrador dos provimentos do exército, António Vicente Teixeira de Sampaio, meditava «em segredo o rompimento da gloriosa acção», tendo para o efeito encetado negociações com as autoridades da Galiza $\left(1^{\circ}\right)$.

(98) Relação fiel e exacta do principio da Revolução de Bragança e consequentemente de Portugal, p. 1 . Na mesma fonte acrescenta-se: «aquele sucesso [a insurreição da Galiza] indicava com o tempo a conjuntura desejada». Cf. Sucessos de Portugal ou Prodigiosa Restauração da Lusitania Feliz. Noticia Historica, e analytica, ou Collecção dos sucessos mais importantes acontecidos em Portugal, desde que as Tropas Francezas enträrão neste Reino com sinistras intenções da mais atroz perfidia, até que delle forão expulsos, $E$ Restabelecimento do Feliz Governo de S. A. R. O Principe Regente Nosso Senhor. Por hum portuguez que ama a religião, a patria, $e$ o seu augusto soberano. Lisboa, 1809, pp. 8-9. pp. 6-9.

(") Relação fiel e exacta...., p. 1. Cf. Sepúlveda Patenteado....,

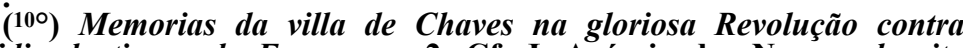
a perfidia do tirano da Europa, p. 2. Cf. J. Acúrsio das Neves, ob. cit., $t$ III, pp. 63-64. O estabelecimento de relações entre os insurgentes espanhóis e portugueses inicia-se com a Proclamação dirigida ao povo português pela junta de Sevilha, suprema do governo de Espanha de 30 de Maio de 1808. (transcrita por S. J. da Luz Soriano, $o b$. cit., segunda ephoca, t. V, parte I, pp. 52-54). Apesar dos contactos referidos, só muito mais tarde, em 5 de Julho é divulgada a Proclamação do Reino da Galiza ao de Portugal (Ibidem, pp. 54-56; e Collecção de Proclamações e editaes, s.l., s.d., fis. 51-52). Nessa data é 
Em Vila Real, o general Francisco da Silveira Pinto da Fonseca tornava-se porta voz dos mesmos planos e projectos $\left({ }^{101}\right)$.

A comunicação de algumas figuras influentes de Melgaço com os revoltosos da Galiza permitiu também aí, uma cuidada preparação da aclamação do Príncipe Regente (102). O caso de Melgaço ilustra como os antecedentes, mas de uma forma exemplar o poder de contágio destes movimentos insurreccionáis, muitos dos quais activados por agentes espanhóis - no Alentejo e no Algarve a participação destes é mesmo decisiva - e ainda a capacidade de iniciativa insurreccional dos senhores locais, quase sempre identificados com patentes militares, funções burocrático-judiciais e com a hierarquia eclesiástica.

Mesmo quando o acto de libertação não fora suficientemente planeado, isto é, à distância da "populaça enraivecida», em conciliábulos mais ou menos secretos, a voz do padre, do magistrado ou do oficial, surgia como o sinal verde da revolta. Em Braga, quando o arcebispo D. José da Costa Torres manda

também celebrado um tratado entre a Junta do Porto e a da Galiza (S. J. da Luz Soriano, ob. cit., segunda ephoca, t. V, parte I, pp. 57-58). Conhecem-se ainda, uma Proclamação e uma Carta assinadas por Nicolau Mahy da Junta da Galiza dirigidas respectivamente ao povo de Valença e ao juiz de fora daquela vila. (Collecção de Proclamações.... fis. 88-88v; Uma proclamação da Nação Espanhola aos Portugueses, s.d., S.I., Ibidem, fis. 59-60; e outra proclamação aos Espanhois, s.d., s.L, Ibidem, fis. 108-109).

(101) O Heroísmo do General Francisco da Silveira Pinto da Fonseca Proclamado a toda a Nação, Lisboa, 1809. Cf. Sepúlveda Patenteado...., pp. 10-14. Sobre as divergências havidas entre o Conde de Amarante e o general Sepúlveda, a respeito da defesa da Província de Trás-os-Montes, veja-se J. Acúrsio das Neves, ob. cit., t. III, p. 81.

(102) «D. António Maria Mosqueira de Lira, provinciano ilustre do reino da Galiza e aparentado com alguns grandes de Espanha, apresentou-se em Melgaço em casa de seu cunhado Caetano José de Abreu Soares, e anunciando secretamente ao corregedor, que servia de Juiz de Fora, Filipe Antonio de Freitas Machado, aí veio este, e tiveram uma conferencia. A este tempo concorreu também Antonio de Castro Sousa Menezes Sarmento.... Mosqueira tinha vindo prevenido com gente armada que deixara a pouca distância, capaz logo de entrar. Vieram também incorporados o corregedor de Milmanda, o abade de Esteriz e outras pessoas distintas da Galiza; e sendo dia de feira em Melgaço, e por isso de um numeroso concurso, os portugueses se unem aos espanhóis e, em presença do juiz de fora que os observava no campo da feira, soltam alegres vivas ao Principe Regente e detestaçÕes violentas contra Napoleã̃o e os seus delegados.... Não contentes os habitantes de Melgaço com o que haviam praticado dentro dos muros e nos subúrbios desta vila, eles quiseram levar a revolução aos povos vizinhos». (J. Acúrsio das Neves, ob. cit., t. III, pp. 68-69). 


\section{Revoltas e Ideologias}

descobrir as armas reais do paço episcopal «soaram instantaneamente as vozes de aclamação» $\left({ }^{103}\right)$, e era o clero quem mais fortemente as entoava.

Em Guimarães, o corregedor da comarca, António Manuel Borges, ladeado por Monsenhor Miranda, inaugura o movimento libertador e promove com as «mais enérgicas providências» (104), o armamento do povo, acto de funestas consequências para $o$ próprio corregedor.

$\mathrm{Na}$ Covilhã o juiz de fora, temendo a excitação tumultuária das massas populares, procede à arrecadação de todas as armas e munições no almoxerifado, giza um plano de defesa da cidade e só depois manda reunir «os diferentes corpos e classes» $\left({ }^{105}\right)$. Num ambiente de festa, mas ordeiramente, celebrou a cidade a Restauração

É também assinalável o grau de «combinação» e «o acerto de providências» com que se preparou de 16 a 18 de Junho a revolta em Torre de Moncorvo, «apreendendo-se as barcas do Douro desde a foz do Águeda até à do Sabor, para se evitar a passagem aos franceses de Almeida» (106), medida de defesa que sugere a presença de militares na preparação da conjura. A adesão de Miranda do Douro e Trancoso ao movimento libertador iniciado em Bragança ficou igualmente a dever-se à acção de um capitão de ordenanças e de um tenente-coronel de milícias.

Em Tomar, «o povo, que já andava em fermentação» (107), foi rapidamente galvanizado pelo diligente e activo franciscano Frei Manuel da Pesqueira.

$\mathrm{O}$ alastramento das revoltas no meio rural foi em grande parte obra de guerrilhas restauracionistas, frequentemente capitaneadas por elementos do baixo clero e constituídas por pequenos grupos de paisanos. Em magotes armados com chuços, foices e outros instrumentos de trabalho, estes populares prometiam vingar a sua ira e saciar o seu ódio contra o ocupante e os traidores da pátria. A acção desenfreada dos guerrilheiros, promovendo o «frenesim» da plebe nas localidades por onde passavam, atemorizava, naturalmente, as autoridades constituídas, receosas que sobre elas se abatesse o «frémito raivoso» da

(103) Idem, ibidem, p. 61. Cf. Epitome Historico da Acclamação do Principe Regente N. S. na cidade de Braga em 8 de Junho de 1808, Lisboa, 1809.

(1M) J. Acúrsio das Neves, ob. cit, t. IV, p. 330; Relação do que se praticou em Guimarães em Applauso da Feliz Restauração deste Reino, Lisboa, 1808.

(105) Relação de tudo o que se praticou na Villa da Covilhã

relativamente à feliz restauração de Portugal, s.l., s.d., p. 4.

(106) J. Acúrcio das Neves, ob. cit., t. III, p. 82.

(107) Idem, ibidem, t. IV, p. 186. 
populaça. À medida que as circunstâncias o impunham, essas patrulhas de paisanos armados começavam a encaminhar-se para centros urbanos mais vigiados com o intuito não só de sublevar as suas gentes e forçar a rendição dos escassos contingentes militares franceses que aí encontrassem, mas também com o propósito de colher de surpresa as tropas de observação ou de ataque que surgissem no percurso. Este foi o processo utilizado, por exemplo, pela patrulha que saiu do Porto a 21 de Julho pela estrada que conduzia a Coimbra, com o objective de espiar o inimigo. A ela se juntou um conventual da Ordem de Avis, José Bernardo de Azedo. O rasto tumultuário deste grupo de revoltosos armados atingiu Oliveira de Azeméis, Aveiro, Mealhada e Coimbra. Aqui, depois de desbaratada a pequena guarnição francesa, irrompem pela cidade, promovem barricadas nas ruas com o concurso dos de mais baixa condição enquanto «as classes superiores» se aferrolham em suas casas. Os insurrectos logo chamaram a si o tanoeiro e juiz do povo da cidade, José Pedro de Jesus e, após algumas hesitações, com a sua mediação foi escolhido para governador da cidade, o vice-reitor da Universidade Manuel Pais de Aragão Trigoso Pereira de Magalhães $\left({ }^{108}\right)$.

A Universidade, convertida em forte de resistência da cidade, organizou um corpo militar de lentes opositores, doutores e professores, e um corpo de voluntários académicos. Parecendo obedecer a uma cuidada estratégia de defesa, os batalhões académicos dirigem-se, numa primeira fase, para sul, libertam na costa litoral a Figueira da Foz, preparando com esta iniciativa o desembarque das tropas aliadas da Grã-Bretanha comandadas por Artur Wellesley, e avançam em direcção à Nazaré. Atingem, no entanto, o forte desta localidade de pescadores a partir de Leiria, isto é, pelo interior. As incursões dos batalhões académicos para sul e para leste não só contribuíram para a libertação de boa parte da zona centro do país como favoreceram o estabelecimento de relações entre o governo de Coimbra com as províncias do sul, nomeadamente com a Junta de Campo Maior, principal foco de insurreição no Alentejo e, através desta, com a Junta de Badajoz $\left({ }^{109}\right)$.

5.2. $\quad$ O movimento restaurador que em extensão se tornou nacional, evoluiu da periferia para o centro, isto é, das zonas mais desguarnecidas e próximas da fronteira espanhola para

(1<w) Maria Ermelinda de Avelar Soares Fernandes Martins, Coimbra e a guerra peninsular, vol. I, Coimbra, 1944, pp. 141 e ss. (*0T) Idem, ibidem, p. 166. 


\section{Revoltas e Ideologias}

regiões minadas pela presença do exército invasor, como a Estremadura, Alto Alentejo e a Beira Baixa.

$\mathrm{E}$, em todo o caso, assinalável a concomitância dos levantamentos de Entre Douro e Minho com os do Algarve. Também nesta faixa meridional o húmus da revolta se circunscreve a grupos conspirativos que congregavam figuras de prestígio local.

Em Faro constitui-se uma Sociedade Patriótica que reunia clandestinamente em casa do capitão Sebastião Brito Cabreira, nas imediações da igreja da Santíssima Trindade $\left(110^{*}\right)$. Dela sairam e se espalharam por toda a província, proclamações apelando à insurreição organizada. Em vésperas da restauração de Olhão já aí eram lidas outras proclamações clandestinas, uma das quais da autoria do padre Mestre Frei José do Sacramento Pessoa, de Tavira, que a pusera a circular com a aprovação do Conde de Castro Marim (U1). Curiosamente, nesta vila, o grito da restauração foi dado por uma personagem estranha à vida desta localidade piscatória, o governador de Vila Real de Santo António, coronel Lopes de Sousa, que aí acorrera. O desenvolvimento das acções de suporte ao levantamento de Olhão sugerem a existência antecipada de um minucioso plano de defesa. Sabia-se onde e como contar com armamento disponível ao longo da costa, e, o que é mais significativo, da disponibilidade da Junta de Ayamonte em apoiar os revoltosos algarvios $\left({ }^{112}\right)$.

A revolta de Olhão rapidamente contagiou todo o Algarve. Prenhe de patriotismo a cidade de Faro acordou a 19 de Junho ao som de «baladadas anunciadoras de uma mulher aflita com dores de parto» (113). Estava dado o sinal para que o povo em massa acorresse às armas. A falta de munições nesta fase de desbaratamento das forças inimigas forçou $o$ estreitamento de relações dos sediciosos algarvios com as Juntas de Ayamonte,

(110) Outro grupo de patriotas, de mais baixa condição, associado em torno do comerciante Brito Alvares da Silva Cañedo, O Bento ITendeiro, «planeava secretamente a libertação da cidade» (Alberto Iria, ob. cit., p. 62).

(m) Idem, ibidem, p. 36.

("*) Sebastião Drago de Brito Cabreira, Relação Histórica da Revolução do Algarve contra os Franceses que dolozamente invadirão Portugal no anno de 1807. Lisboa, 1809, pp. 8-10; Joaquim Filipe de Landerset, Breve Noticia de Feliz Restauração do Reino do Algarve e mais sucessos até ao jim da marcha do Exercito do Sul em auxílio da Capital, por I. F. L. Official do mesmo exercito. Lisboa, 1809, pp. 7-8.

(113) Frei Joaquim Soares, ob. cit., II, p. 17. 
Sevilha e Cádis (114). A proximidade e a frequência de contactos com o outro lado da fronteira teve, igualmente, importantes repercussões no que toca à institucionalização das revoltas restauracionistas nesta província (115). Na capital erigiu-se um poder central com atribuições políticas, administrativas e militares, a Regência de Faro, e por meio de uma constituição provisional se estabeleceu um plano de articulação desta com as Juntas que entretanto se iam constituindo nas diferentes comarcas (116). Sob a direcção do Conde de Castro Marim, mais tarde marquês de Olhão e governador do reino, Francisco de Melo de Cunha e Meneses, a Regência procedeu à organização de destacamentos militares cujo objectivo era levar o Alentejo a seguir o exemplo do Algarve.

Mas já por essa altura haviam soado vozes de insurreição naquela província. Os primeiros ecos da revolta espanhola fizeram-se sentir na fronteira alentejana com alguma antecipação. Em Maio, os revoltosos de Madrid e Sevilha faziam chegar a estas povoações manifestos e emissários que as incitavam à rebelião armada $\left({ }^{117}\right)$.

Vila Viçosa e Beja, magnetizadas pelo exemplo da resistência espanhola e atentas ao desenrolar do movimento restaurador interno iniciam a 19 e 24 de Junho respectivamente, a

(114) Pescadores e militares demandaram igualmente Gibraltar e Marrocos e estiveram em contacto com a esquadra inglesa. Vide Feliz Restauração do Reyno do Algarve, e mais sucessos atine à concluzão da marcha das Tropas do mesmo Reyno em auxílio da Capital, in, Alberto Iria, ob. cit., pp. 319 e 321. Cf. J. Acúrsio das Neves, oh. cit., t. III, p. 154.

(115) A pretexto do armamento concedido ao capitão Martins Mestre, «exigiu a Junta de Sevilha entre outras obrigações, que o referido capitão procedesse à criação de Juntas governaitvas não só no Algarve mas também no Alentejo, dependentes da sua autorização. Em Sevilha instalar-se-iam representantes das mesmas para directamente tratarem dos negócios relativos a Portugal» (Alberto Iria, ob. cit., p. 113). Na sequência de alguns desacatos cometidos pelas tropas espanholas, a Regência de Faro e a Junta de Sevilha assinaram um tratado recíproco de aliança militar, com o reconhecimento da legítima soberania e independência do Algarve (Sebastião Drago de Brito Cabreira, ob. cit., pp. 17 e 18).

$(n \ll){ }_{r} \cdot d_{\mathrm{aC}}$ ção do plano de Constituição Provisional para as Juntas fora confiada pelo Conde de Castro Marim ao padre Mestre Frei José do Sacramento Pessoa. Veja-se documento mencionado por Alberto Iria, ob. cit., pp. 450-451.

(117) E o que se infere do relatório do intendente geral da Polícia, Lagarde, datado de 11 de Maio de 1808 «Le Corrégidor [de Ourique] pense qu'en faisant courir cette lettre sur le territoire Portugais, leur intention était d'engager aussi les habitants de ce Royaume à se révolter» (documento transcrito por Antonio Ferrão, ob. cit., p. 341). Veja-se na mesma obra, a informação do juiz de fora de Penamacor, p. 351. 


\section{Revoltas e Ideologias}

libertação do Alentejo. Apenas nestas duas localidades os populares agiram por si, desencadeando as primeiras acções de revolta sem que se pressinta qualquer mediação dos senhores locais. Constituem portanto, dois casos isolados que contrastam com o que, na generalidade, aconteceu em todo o país.

Em Vila Viçosa o sinal da rebelião foi dado à porta da igreja quando o povo se preparava para assistir à missa dominical. $\mathrm{O}$ toque a rebate rapidamente fez engrossar o tumulto. Mas logo o desalento se instalou na massa revoltosa, ao considerar-se a possibilidade de uma acção de represália do forte contingente militar estacionado em Eivas: «ocorre então a necessidade de procurar auxílio de um chefe que comanda» (118). Depois da recusa do general Francisco Paula Travassos, o sargento-mor de milícias, António Lobo Infante, toma o comando da «população amotinada». Incapaz de dirigir a resistência foge para Badajoz a pedir socorros $\left({ }^{119}\right)$.

Beja insurreciona-se quando os seus habitantes recusam aceder à requisição de mantimentos exigida pelo destacamento francês em fuga, vindo do Algarve. Aqui também «os magistrados temendo o perigo próximo quiseram ainda sufocar estes movimentos propondo ao povo que deviam esperar uma melhor ocasião para o rompimento» $\left({ }^{12}\right)$.

Após o malogro destas iniciativas a defesa e o plano de resistência do Alentejo passam deliberadamente a ser confiadas a generais espanhóis das Juntas de Badajoz e Sevilha. Muitos paisanos preferiram mesmo alistar-se em Espanha e aí integrar as diligentes legiões de voluntários destinadas a combater em Juromenha, Campo Maior, Borba, Vila Viçosa, Estremoz, Évora e outros pontos de menor interesse (121).

A acção das legiões espanholas não se confinou apenas às questões de estratégia militar. Em Marvão, «os chefes espanhóis entraram a exercer actos de jurisdição tão soberanamente que excitaram a emulação e mesmo o descontentamento dos portugueses» (122). De Juromenha, ponto de concentração militar, partiram constantemente emissários e proclamações assi-

(118) J. Acúrsio das Neves, ob. cit., t. III, p. 157.

(118) Teodoro Josef Biancardi, Sucesos de la Provincia del Alentejo escritos por Teodoro Josef Biancardi, Y vertidos del portuguez, Algeciras, s.d., pp. 20-22.

$\left(12^{\circ}\right)$ J. Acúrsio das Neves, ob. cit., t. III, p. 165; Cf. Teodoro

Josef Biancardi, ob. cit., pp. 74 e 75.

(121) Sobre a legião de voluntários estrangeiros de 1808 veja-se Francisco Augusto Martins de Carvalho, Guerra Peninsular, Notas, Episódios e extractos curiosos, Coimbra, 1910, p. 9.

(122) J. Acúrsio das Neves, ob. cit., t. III, p. 174. 
nadas por D. Francisco Moretti para as terras mais próximas. A presidência da Junta de Campo Maior foi entregue a D. Nicolau Moreno de Monroy. Em Estremoz D. Frederico Moretti procede à instalação da Junta Suprema do Alentejo, pretensão nunca reconhecida pelas de Campo Maior e Beja (123). Para atenuar a contenda e facilitar a articulação das Juntas subalternas das diversas comarcas, a Junta de Estremoz abdicou do seu título de suprema em favor da de Évora presidida pelo arcebispo D. Frei Manuel do Cenáculo Villas Boas. Apesar de efémera esta criação indicia, claramente, o grau de ligação e a similitude institucional e orgânica das Juntas do Alentejo com as da Estremadura espanhola e Andaluzia.

Meteoricamente, Évora cai sob a alçada das tropas de Loison. A notícia dos massacres, roubos e atrocidades cometidos nesta cidade produziu um incontrolável «frenesim» (124). Essa onda tumultuária, nascida de um medo incontido e de um ódio inquebrantável contra os franceses e seus apaniguados, ao propagar-se fez momentaneamente ruir todas as barreiras sociais que até ali tinham sido mantidas em equilíbrio precário. Assim se cometeram «homicídios cruéis e injustos.... sem respeito a personagem alguma» (125). Nos sítios em que «soaram na populaça vozes de traição» (126) moveram-se buscas desenfreadas a personalidades até com provas dadas de patriotismo. Se dificilmente o juiz de fora de Estremoz escapava às garras do povo «em delírio», já o corregedor de Évora, José

(123)Rellação do que se obrou na Villa de Estremoz depois que alli se recebeo a noticia da Feliz Restauração deste Reino, s.l., s.d..

(12M) Narração Historica do combate, saque e crueldades praticadas pelos Franceses na cidade de Evora, e noticias do Estado da Provinda do Alentejo, antes daquelles factos, s.l., s.d.; José Joaquim da Silva. Evora Lastimosa pela deplorável catástrofe do fatal triduo de 29, 30 e 31 de Julho de 1808. Memoria Historica dos acontecimentos relativos especialmente ás corporações Ecclesiasticas de hum e de outro sexo. Dividida em Duas Partes: offerecida ao Illmo e Exmo Sr. Marquez d'Olhâo. segunda parte Lisboa. 1808.

(125) jprei $M_{\text {anue }}$ i $d_{0}$ Cenáculo Villas Boas, Memoria Descriptiva do Assalto, Entrada e Saque da cidade de Evora pelos Francezes, em 1808, Évora, 1887. p. 18. Vale a pena referir o dramático episódio passado com o respeitável arcebispo. Já depois da partida dos franceses, ficando a assegurar o governo da cidade foi bruscamente acometido «por uma tropa de contrabandistas, armados de tabucos, punhais, pistolas, espingardas e espadas», vinham com o encargo de o levar «vivo ou morto» à presença da Junta de Beja. Rodeado «por uma escolta maligna e insolente» chegou a Beja, onde depois de ter sido publicamente exibido, permaneceu preso durante dois meses. (Idem, ibidem, pp. 18 e 20 ).

(12e) J. Acúrsio das Neves, ob. cit., t. IV, p. 255. 


\section{Revoltas e Ideologias}

Paulo de Carvalho, acabaria «injuriado, arrastado, morto e decapitado» $\left({ }^{127}\right)$.

5.3.A frequência de «incivis atrocidades» (128) nesta fase das revoltas em que flagrantemente as autoridades civis e religiosas perdem o controlo dos insurrectos, ficando por isso à mercê da tempestade popular, foi uma constante de norte a sul. Apesar da capacidade de iniciativa insurreccional que as classes dominantes revelaram importa acrescentar que muitos dos tumultos se desenrolaram sem elas e, por vezes, até, contra elas (129). Digamos que o mesmo sentimento de patriotismo e fidelidade produziu efeitos distintos, consoante as classes sociais que os exprimiam. As classes dominantes procuraram subordinar a manifestação desse espírito a suportes institucionais acidentais, as Juntas, que salvaguardavam a sua capacidade de exercício do poder administrativo e judicial. Mas a cólera popular parecia não caber nos limites dessa ordem provisória, os princípios de sedição e desorganização brotavam quase espontaneamente entre os de mais baixa condição, nestes «o patriotismo convertia-se em furor» $\left(1^{\circ}\right)$.

Preservando uma organicidade institucional típica de antigo regime, isto é, assente no princípio da representação das três ordens - clero, nobreza e povo - as Juntas raramente deixaram de agir em função dos justificados temores das classes dominantes. Para sufocar e reprimir as desordens e ofensas da plebe forjaram-se, a cada passo, juízes de inconfidência. Os objecti vos que invariavelmente presidem ao processo de constituição das Juntas expressam-se com clareza nos pressupostos da criação da Junta de Segurança e Administração Pública de Torre de Moncorvo, cuja designação é já por si reveladora. Assim, na opinião do seu presidente, Tomás Inácio de Morais

(m) Sentença proferida no Tribunal Supremo da Caza da Supplicação, por especial comissão do Principe Regente Nosso Senhor, julgando a innocencia e fidelidade do dezembargador José Paulo de Carvalho, Corregedor que foi da Comarca de Evora. B. N. L., Mss. 220, n. ${ }^{\circ} 69$ a fl. 6.

(128) Frei Manuel do Cenáculo Villas Boas, ob. cit., p.

$\left.C^{29}\right)$ Situação invariavelmente mencionada na documentação da época. A título de exemplo referiremos o testemunho do juiz de fora de Lagoa, José Francisco d'Albergaria Corte Real, que esteve prestes a ser assassinado, segundo o seu testemunho, «tiveram principio os tumultos até esse ponto evitados pela prudencia com que tudo tinha sido dirigido.... e que depois chegaram a ponto de romper quase uma guerra civil» (doc. transcrito por Alberto Iria, ob. cit., p. 419).

(130) J. Acúrsio das Neves, ob. cit. $_{J}$ t. IV, p. 288. 
Sarmento, a Junta deveria «não só evitar os males da anarquia e da Galomanía» como atenuar e travar «a convulsão patriótica» $(131)$ que afectava aquela comarca.

Este processo não foi linear nem imediato. Com incidência regional variável registaram-se algumas tentativas de acesso ao poder político das Juntas, protagonizadas por gente de baixa condição, onde se pressente a existência de elementos das burguesías locais, tentativas sem exito e de curta duração. Os casos mais flagrantes são os de Viseu e Arcos de Valdevez. No primeiro sítio, os populares aproveitando a surda disputa de jurisdição entre o bispo e a hierarquia militar, elegeram um juiz do povo, «emprego que não costumava haver naquela cidade» (132), que com mais vinte e quatro indivíduos deram corpo à nova Junta denominada Junta dos Prudentes - a similitude com o modelo corporativo da Casa dos Vinte e Quatro é, neste caso, surpreendente. Foram depostos e presos, depois de perseguidos, injuriados e devassadas as suas residências, o general, o juiz de fora e outras personalidades de menor vulto. $\ddot{A}$ testa destas acções tumultuárias esteve sempre o juiz do povo. Quando, porém, em 11 de Julho, o espírito inflamado da plebe ruboreceu num ajuntamento de mais de três mil pessoas, o timorato e efémero juiz do povo de Viseu abdicou do seu poder de mando em favor da autoridade legítima do bispo, nunca aliás directamente posta em causa pelos revoltosos - sinal evidente de um conflito sem espessura revolucionária. Os velhos elos de obediência só parcialmente se tinham quebrado.

Os motins de Arcos assumiram proporções mais inquietantes: o juiz de fora foi deposto, espancado e preso; os reclusos postos em liberdade, os paços do concelho devassados e os processos e documentos públicos dos cartórios entregues às chamas. Tal como sempre acontecia, formou-se uma Junta constituída por «três seculares e dois eclesiásticos» (13S). A acção desta Junta causou ainda mais comoção pública quando intentou impor à escala nacional «leis contrárias às do reino e tendentes à subversão da monarquia» $\left({ }^{134}\right)$. Tudo indica que a

(131) Vide Papeis Offiçiaes da Junta da Segurança e Adminis-

tração Publica da Torre de Moncorvo, onde foi proclamada a legitima autoridade do Principe Regente Nosso Senhor no dia 19 de Junho de 1808 , Coimbra, 1808, p. 3. Através destes documentos e particularmente do edital de 29 de Julho, retivemos que, aqui, as mulheres eram um dos agentes da insurreição que maiores cuidados inspiravam às autoridades públicas; Cf. Collecção de Proclamações e Editaes................... fl. 84.

(132) J. Acúrsio das Neves, ob. cit., t. IV, p. 31.

(133) Idem, ibidem, p. 324.

(134) Vide Sentença proferida na correição do crime da cidade do Porto, contra os amotinados tumultuarios na Vila de Arcos de Valdevez, em 10 e 11 de Julho de 1808 (Idem, ibidem, p. 326). 


\section{Revoltas e Ideologias}

Junta de Arcos de Valde vez materializou circunstancialmente as aspirações imediatas da plebe e, a par destas, os inconfessados desígnios de uma burguesia local pouco afoita que, nesta prova de força, se escudara na acção e no discurso radical de um estudante universitário de Coimbra. Não houve, contudo, uma estratégia e um projecto político coerentes apesar da veleidade de tornar extensivo a todo o reino, o modelo insurreccional de Arcos (135). Para o silenciamento desta e doutras veleidades do terceiro estado muito contribui a vigilância e prática conservadora da Junta Provincial do Supremo Governo do Reino erigida no Porto. Para lá foram conduzidos para serem julgados e sentenciados, os cabecilhas das insurreições de Arcos e Viseu.

As motivações que perpassam os motins que acabámos de descrever subjazem, com menor força, a outras situações de conflito. Na impossibilidade de os referirmos de forma exaustiva, limitar-nos-emos a analisar os comportamentos dos grupos sociais envolvidos nas revoltas do norte e, particularmente, naquelas em que as dicotomias esboçadas em 1808 se vão tendencialmente repetir e/ou agravar durante a segunda invasão francesa, isto é, com a entrada das tropas de Soult pelo Minho, em Março de 1809.

Comecemos pelo Porto. Do «estado de fermentação» (138) vivido na capital nortenha, em fins de Junho de 1808, nos dão conta as proclamações do bispo e presidente da Junta, do intendente geral da Polícia e do próprio juiz do povo $\left({ }^{137}\right)$. Este último mais próximo da sensibilidade e do agir popular exclamava, nesta fase alta da febre insurreccional: "Vossa fome não está saciada, vossa raiva se aumenta.... enfim, ninguém vos pode conter» (138). Mas a força do povo era, naquela ocasião, bem o sinal da sua fraqueza, como observara o bispo D. António de S. José de Castro. Por isso, com êxito, as autoridades insistentemente convidavam os revoltosos a prestarem sujeição à Junta do Supremo Governo sempre com a advertência de que

(135) Vide Graça e J. S. da Silva Dias, Os Primórdios da Maçonaria em Portugal, vol. I, t. II, Lisboa, 1980, pp. 523-524; Cf. Vasco Pulido Valente, "'O povo em armas' a revolta nacional de 1808-1809», Análise Social, vol. XV (57), 1979, p. 14.

(136) J. Acúrsio das Neves, ob. cit., t. IV, p. 285.

(13T) Vide Collecção de Proclamações e Editaes, fis. 20-20 v, 22-23, 26-27, 28-29; Cf. J. Acúrsio das Neves, ob. cit., t. IV, pp. 285-288 e S. J. da Luz Soriano, ob. cif., segunda ephoca, t. V, parte I, pp. 79-82. I, p. 81 .

(138) S. J. da Luz Soriano, ob. cit., segunda ephoca, t. V, parte 


\section{Revoltas e Revoluções}

preferiam «dar a vida em benefício da pátria do que sacrificá-la em tumultos» $\left({ }^{139}\right)$.

O início da restauração do Porto fora já assinalado por um motim de feição ambígua em que a fome e a penúria de grãos tendiam a reforçar o sentido da revolta política. $\mathrm{O}$ episódio resume-se a poucas palavras. A pedido do juiz de fora de Oliveira de Azeméis mandara o então governador da cidade, Luís de Oliveira da Costa, abastecer «de ração» alguns carros que deveriam ir municiar a coluna dirigida por Loison que tinha saído de Almeida com destino à região de Entre Douro. $« \mathrm{O}$ povo alterou-se junto ao assento na tarde do dia 18, quando se estavam carregando os carros, e misturando-se no ajuntamento alguns dos artilheiros, um deles levantou a voz e disse que só para os portugueses não havia pão» (140). $\mathrm{O}$ desenrolar da revolta permite pôr em evidência que a escassez de pão provocou uma fome incomparavelmente menos aguda que a sede de vingança manifestada pelo povo contra os reais ou presumíveis protectores dos invasores $\left({ }^{141}\right)$. Assim, as ocasiões que com maior frequência motivaram o «alarido» das massas populares foram no Porto, como por toda a parte, sempre as mesmas: o rebate falso anunciador de um ataque imprevisto, a descoberta de algum mensageiro que se encaminhasse para zonas de influência francesa, e a acusação de afrancesamento sempre difícil de provar. Enfim, os fantasmas de medo e traição não deixavam de agitar os povos.

A explosão do ódio popular contra os franceses e seus apaniguados assume, pontualmente, durante a segunda ocupação do Porto pelo exército de Soult, o carácter de autêntica rebelião social. Os antagonismos sociais latentes desde Junho de 1808 avolumam-se e precipitam-se a 21, 22 e 23 de Março de 1809 com assassínios, espancamentos de altas patentes do exército, magistrados e negociantes. A par disso, devassaram-se casas particulares, arrombaram-se prisões, massacraram-se alguns detidos e moveram-se saques a habitações e propriedades. Os rebeldes foram mais tarde identificados. $\mathrm{Na}$ sua grande

(13£>) J. Acúrsio das Neves, ob. cit., t. IV, p. 286.

(140) Idem, ibidem, t. Ill, p. 88.

(141) No sentido de atenuar a escassez de pão, o presidente da Junta Provisional do Governo Supremo determina em edital de 2 de Agosto «que na conformidade da Carta de Lei de 4 de Fevereiro de 1773, e debaixo das penas dela se não ponha embaraço algum ao livre giro, e transporte de todas as espécies de grãos e farinhas, que se conduzirem de umas para outras terras do Reino, não sendo para as que se acham ainda ocupadas pelo inimigo", in Colleç̧ão de Proclamações e Editaes...., fl. 74. 


\section{Revoltas e Ideologias}

maioria eram gente de ofícios mecânicos com os quais haviam pactuado uma regateira e alguns soldados e letrados (142).

De Junho e Julho de lb08 a Março de 1809, reavivam-se em Braga, Chaves, Viana do Castelo, Barcelos, Bragança e Vila Nova de Foz Côa ancestrais tensões sociais que se encobrem e confundem com argumentos de natureza política. A linha de demarcação do social e do político, mais tracejada do que contínua, é nestas convulsões extremamente difícil de traçar. Não ambicionamos explorá-la mas tão-só sugerir a sua complexidade com o caso de Braga. Aqui o primeiro bode expiatório da revolta foi o dono de uma fábrica. A plebe não se contentou em espancar e pilhar, só serenou ao ver a fábrica reduzida a chamas $\left({ }^{143}\right)$. Ninguém se mostrava capaz de conter a fúria da multidão que corria pelas ruas, e transpunha as fronteiras da cidade avançando para o terreno das operações militares apostada em enfrentar, sem direcção nem comando, as tropas de Soult. Ao entrar em Braga, no dia 17 de Março, o general-em-chefe do exército português, Bernardim Freire de Andrade, $\operatorname{logo}$ se apercebeu da extensão e gravidade do levantamento popular e, concluindo pela impossibilidade de concretização do plano de defesa da cidade, manda recolher e retroceder os seus postos avançados. Foi quanto bastou para que, apodado de traidor, fosse massacrado e morto $\left({ }^{144}\right)$.

Como se verifica, os amotinados transferem e confundem o objecto da revolta, o francês e o afrancesado, invectivando e agredindo os poderosos e os ricos «por detrás do ocupante, e sem que deixasse de funcionar como detonador, fundamento e legitimação da violência manifestaram-se com crescente força e clareza os antagonismos básicos da sociedade nacional» $\left({ }^{145}\right)$.

\section{O clero e a ideologia da Restauração}

6.1. Nos longos e ambíguos processos de identificação dos opressores sociais aos agressores políticos foram ainda envolvidos judeus e descendentes cristãos novos como que sugerindo o perdurar de um velho espírito segregacionista católico, trave mestra da mentalidade de «antigo regime» português que,

(142) Sentença da Alçada do Porto proferida em 27 de Fevereiro de 1810, Porto, 1810. pp. 13-14.

(143) José Valério Veloso, Memoria dos Factos Populares na Provinda do Minho em 1809, onde forão sacrificados os chefes do Exército e outras muitas pessoas marcantes, Porto, 1823.

$\left.{ }^{144}\right)$ Idem, ibidem, e António Pedro Vicente, Um soldado da

Guerra Peninsular, Bernardim Freire de Andrade e Castro, Lisboa, 1970.

(145) Vasco Pulido Valente, art. cit. p. 14. 


\section{Revoltas e Revoluções}

apesar de formalmente extinto pela legislação pombalina, permanecia vivo e actuante. O judeu, estigma de desconsideração social e inferioridade moral e religiosa e também símbolo de usura e opulência económica, funcionou como catalizador do descontentamento popular em enclaves geográficos de tradição cristã-nova como Bragança, Moncorvo, Guarda, Viseu, Covilhã, Fundão e Vila Nova de Foz Côa. A população desta vila, instigada entre outros, por um clérigo, manteve-se «levantada» contra os franceses e os judeus «que os protegiam» durante aproximadamente quinze dias provocando, em fins de Julho e princípios de Agosto de 1808, «a total ruína de vinte e tantas famílias das mais ricas da terra» $\left({ }^{14 \mathrm{e}}\right)$. Nem as providências tomadas pela Junta de Segurança e Administração Pública de Torre de Moncorvo conseguiram evitar as contínuas perseguições, pilhagens e destruições que chegaram mesmo a atingir outras localidades próximas $\left({ }^{147}\right)$. Em Outubro de 1809, estas mesmas manifestações de hostilidade contra os jacobinos e judeus repetem-se, ainda que com menor intensidade.

A mentalidade ultramontana ao tomar os suspeitos de «afeição» aos franceses, os jacobinos ou franchipanas, por judeus e vice-versa, deixava aberta a porta para que paralelamente aos tribunais civis, a Igreja, através da Inquisição, interviesse no julgamento e repressão dos reais ou imaginários motores da revolta. É isso que se depreende da sentença lavrada em 4 de Agosto relativa aos tumultos de Foz Côa que, «pronunciando um grande número de culpados, mandou remeter para o Tribunal da Inquisição de Coimbra, as culpas respectivas à religião» $\left({ }^{148}\right)$.

Se a ressurgência do antisemitismo, como aliás do sebastianismo, só podem compreender-se no quadro de uma mundividência, senão estática, pelo menos impregnada de duráveis permanências, também o arrastamento para o campo religioso do fantasma político do afrancesamento, pelo aproveitamento de ancestrais clivagens sócio-religiosas, patenteia, em última instância, a força da ideologia clerical nos primórdios da sociedade portuguesa de oitocentos. Fenómeno que em grande me-

(146) J. Acúrsio das Neves, ob. cit., t. IV, p. 304; Cf. Rafael Marçal, Os marçais de Fozcôa, Lisboa, 1939.

(147) Papeis officiaes da Junta de Segurança e Administração

Pública da Torre de Moncorvo...., pp. 14 e 15.

(14S) J. Acúrsio das Neves, ob. cit., t. IV, p. 309. Com objectivo idêntico foi forjada, em Lisboa, uma lista de judeus afrancesados (Cit. por Albert Silbert, «Les invasions françaises et les origines du libéralisme au Portugal», Revista de Historia das Ideias, II, Coimbra, 1978-1979). 
dida explica que os movimentos insurreccionáis de 1808 e 1809 , mesmo com os seus pontuais desvios e incursões no tecido social do «antigo regime», tivessem sido comandados por um patriotismo de «estrita observância» à realeza e à religião católica e, por isso, sempre canalizados para a imagem do ocupante como satânico opressor, ímpio, saqueador de igrejas e, da mesma forma, para os seus agentes internos que acabariam recrutados entre os reais e também imaginários antagonistas sociais, os jacobinos e os judeus, isto é, os potenciais subvertores simultaneamente da ordem política e religiosa.

De facto, foi o clero que deu um conteúdo ideológico à luta que então se travava «impedindo que ela se concebesse como uma luta pela pátria, contra o estrangeiro e contra os senhores (magistrados, militares, chefes da igreja) que com ele, em diversos graus, haviam pactuado, transformando-a numa guerra de religião em que o inimigo francês ou português, surgia sobretudo como o inimigo de Deus, o jacobino, o anarquista» $\left({ }^{149}\right)$. Para o triunfo desta visão muito contribuiu o

(149) Vasco Pulido Valente, art. cit., pp. 25-26. Neste sentido, são particularmente elucidativos os apelos dirigidos ao clero. Salientamos apenas estes: «Eclesiásticos, ensinai os povos em particular, e em público quais sejam as suas obrigações nesta circunstância» Hum Portuguez segunda vez aos Portuguezes, Lisboa, 1810, fl. 1 (folha distribuída gratuitamente); «Sim, é um Sacerdote, um Religioso, um Prelado respeitável, um santo enfim, que hoje vemos colocado sobre os nossos altares, quem desembainha a espada contra os inimigos da Religião e da Pátria. Duvidaremos nós seguir o seu exemplo?.... Seja pois um Eclesiástico quem desafronte a honra da Patria ultrajada, quem vingue o proprio Estado da injusta perseguição que os Franceses lhe fizeram", (Portugal. Desafrontado. Dialogo entre hum official francez da legião do meio-dia, e hum ecclesiastico da provinda D'Entre-Douro $e$ Minho. Dedicado aos verdadeiros Portuguezes Restauradores da Patria. Por hum clérigo secular da mesma provinda, s.l., s.d., pp. 5-6). Numerosas proclamações e pastorais apontam no sentido do fortalecimento do papel do clero na condução das revoltas, como o atesta este passo da autoria do Provisor do Bispado de Coimbra, António José Vieira dos Guimarães: «Agora com maior razão, que a Causa Publica está ligada com a Religião, agora que a Causa Pública é muito espeçialmente a nossa Causa, Ó Clérigos Seculares, e ainda mais vossa, ó Regulares. Corramos todos animosamente às armas», Collecção de Proclamações e Editaes, fis. 24-25; o mesmo documento encontra-se transcrito em Maria Ermelinda Avelar Soares Fernandes Martins, ob. cit., t. II, pp. LIII-LV. Vejam-se ainda a Proclamação aos Senhores ecclesiasticos seculares do Deão da Sé do Porto, Luis Pedro de Andrade Brederod, (Idem, fl. 8) ; a Proclamação aos Cidadãos Religiosos, vassalos Portuguezes nos Claustros de Francisco (Idem, fl. III, cit. por Raul Brandão, El-Rei Junot, Lisboa, 1982. p. 222); A Proclamaçã̃o do Bispo de Aveiro, D. António José Cordeiro, de 13 de Julho de 1808. (Idem, fis. 44-45). 


\section{Revoltas e Revoluções}

exemplo de combatividade do clero que, desde a primeira hora, esteve nas trincheiras da insurreição.

6.2. Os padres e os frades não só acorreram às armas como se prontificaram a distribui-las ao povo. Desta missão se encarregaram, no Porto, os dominicanos $\left({ }^{150}\right)$. Estes mesmos religiosos desenvolveram em Lamego, Amarante e Guimarães notáveis acções de resistência.

No Norte e no Centro do país constituíram-se, por iniciativa própria ou com a aprovação dos prelados das respectivas dioceses, batalhões eclesiásticos. O arcebispo de Braga, D. José da Costa Torres, colocou-se, com o título de general, à frente de um batalhão eclesiástico cuja criação promovera; na diocese de Aveiro, o bispo D. António José Cordeiro manda armar todos os eclesiásticos regulares e seculares; por indicação do bispo da Guarda, D. José António Pinto de Mendonça Arrais, outro corpo militar de eclesiásticos surge; no Porto, o bispo D. António de S. José e Castro instiga os seus prelados a participarem activamente na defesa da cidade (151). Ainda aqui constituiu-se um regimento para a guarda do paço, do qual foi coronel o deão da Sé, Luís Pedro de Andrade Brederod. Em Chaves organizou-se outra companhia de eclesiásticos «não menos valorosos que respeitáveis pelas suas conhecidas e exemplares virtudes» (152). Ao seu comandante frei António de Assunção atribuiu-se também um posto da hierarquia militar, o de major.

A par dos batalhões académicos, os eclesiásticos de Coimbra, que em 18 de Julho corriam à frente do povo e das ordenanças, formam um corpo de voluntários com mais de 350 alistamentos, chefiados pelo reitor do seminário episcopal, José da Costa e Silva (153). Até o Tribunal do Santo Ofício promoveu, em finais de 1808, a criação de um batalhão patriótico com os seus familiares residentes em Lisboa e seu termo (154).

Nas zonas de montanha, de Trás-os-Montes à Guarda e de Viseu a Viana do Castelo, mais propícias ao alastramento de guerrilhas, distinguiram-se alguns guerrilheiros de hábito como

(iso) $\mathbf{p}_{\mathrm{re}} \mathrm{i}$ Joaquim Soares, ob. cit., I, p. 32.

(151) Vide Fortunato de Almeida, História da Igreja em Portu-

gal, vol. III, Barcelos, 1970, pp. 497, 511, 543, 581.

(152) Memorias da Villa de Chaves...., pp. 27-28.

(153) Vide Minerva Luzitana, n. ${ }^{\circ} 6$ de 18 de Julho de 1808 e Maria Ermelinda de Avelar Soares Fernandes Martins, ob. cit., t. I, pp. 173-174.

(154) Fortunato de Almeida, ob. e vol. cits., pp. 424-425. 
os lendários mestre índio, frei António Pacheco e o frade de hábito branco, frei Joaquim de Jesus Mesquita e Ascenção. O primeiro, dominicano, notabilizou-se na zona de Guimarães (155), o segundo, comandando uma pequena guerrilha, causou grandes embaraços ao avanço das tropas de Loison, na Régua (156). Na mesma altura, nas margens do Douro, outro religioso capucho, frei Pedro de Parada Cunhos, corria armado capitaneando um magote de paisanos (157). Ainda em 1810, durante a terceira invasão, e mau grado as recomendações contrárias do exército associado anglo-luso, surgia perto de Sabugal, Bernardo Dias, cura do Vale de Espinho, com uma guerrilha que chegou a entrar em Espanha (158).

Com exércitos particulares ou sem eles os religiosos assumiram-se como briosos soldados, respeitados, venerados e entusiasticamente seguidos pelo povo. Captando o espectáculo ruidoso das campanhas armadas dirigidas por clérigos, frei Joaquim Soares escrevia: «Pensava-se ver renovadas as Cruzadas, e na verdade estas guerras eram mais justas porque os inimigos eram piores» $\left({ }^{159}\right)$. A observação é do maior significado porque traduz, exactamente, o espírito que norteava a acção dos religiosos e, simultaneamente, a teia de valores e referentes históricas que, cruzando-se, conferiam a necessária legitimidade e universalidade ao discurso religioso desta época. Fazendo submergir o interesse público em favor da causa religiosa e, consequentemente, conferindo ao clero secular e regular «a tarefa de consumar a santa e justa empresa» $\left({ }^{160}\right)$ da Restauração, a Igreja tendia a transformar a resistência contra o invasor numa autêntica luta de fiéis.

Poucas vozes se ergueram contra a tentação guerreira ou mesmo cruzadística do clero do norte, da Estremadura e do

(155) Minerva Luzitana, Supl. ao n. ${ }^{\circ} 5$ de 12 de Outubro de 1808 e ${ }^{\circ} 53$ de 22 de Outubro.

(156) Gazeta de Lisboa, ${ }^{\circ}{ }^{\circ}$ 57, de 7 de Março de 1810; Minerva

Luzitana, n. ${ }^{\circ} 3$ de 15 de Julho de 1808; Cf. Raúl Brandão, ob. cit., p. 225.

(157) Minerva Luzitana, $n .^{\circ} 9$ de 21 de Julho de 1808.

(138) Gazeta de Lisboa, n. ${ }^{\circ} 311$ de 28 de Dezembro de 1810.

(is») Frei Joaquim Soares, ob. cit., I, p. 3. Vejam-se também José Antonio da Silva Freire, Apologia dos Ecclesiasticos Armados para defensa da Patria, Lisboa, 1809; Frei Fortunato de S. Boaventura, $A$ Religião Offendida pelos seus chamados protectores, ou manifesto das injurias que o governo francez intruso em Portugal ha feito à religião catholica romana $e$ aos seus ministros dirigido $e$ proclamado a todos os Portugueses, Coimbra, 1809. Grito de hum verdadeiro portuguez, Lisboa, 1809.

(1C0) Carta Pastoral do Provisor do Bispado de Coimbra, António José Vieira dos Guimarães de 10 de Julho de 1808, in Collecção de Proclamações e Editaes, fis. 24-25. 


\section{Revoltas e Revoluções}

Algarve. Pouco significativas em número, fizeram-se no entanto, ouvir. D. Frei Manuel do Cenáculo, arcebispo de Évora, em edital de 30 de Julho de 1808 (161), na condenação que faz destes excessos, representa bem a linha divisória que distanciava o ultramontanismo dominante de um irenismo evangélico de inspiração humanista e neste autor, igualmente próximo da mentalidade ilustrada de finais do século XVIII.

Não foi talvez por acaso que as velhas barreiras de veneração e respeito que sempre tinham existido entre a plebe alentejana $\mathrm{e}$ os seus tradicionais guias espirituais tivessem aluído tão rapidamente. Por essa experiência passou, singularmente, o próprio Arcebispo de Évora. Convém ainda notar que apenas no Alentejo o clero se manteve ausente da organização e direcção dos tumultos.

6.3. A insurreição popular, que chegou a assumir inequívocas motivações sociais, culminou num estreitamento de fidelidade da nação à realeza, à ordem moral e à tradição histórica. A religião católica, baluarte da ordem ético-social, funcionou na parenética da Igreja como elemento de coesão ideológica e travão do espírito sedicioso. A escolha do padre, símbolo de fortaleza espiritual e da sacralização e legitimação do poder, não deve dissociar-se da "eleição» do militar, agente virtual da força e da disciplina, na condução dos revoltosos, através das Juntas locais, ao antigo estado de coisas.

Os momentos que melhor caracterizam o sentido, amplitude e permanências das revoltas durante o período da guerra peninsular que se estende até 1814, situam-se em 1808 e 1809. A partir de 1810 confia-se a defesa da independência territorial ao exército anglo-luso mas, a resistência à presença e/ou influência francesa continuou, no plano da imprensa e da opinião pública, norteado por valores e objectivos já enunciados durante a primeira e segunda invasões.

É possível surpreender no vasto manancial de proclamações de oito e nove as directrizes político-ideológicas que enformam a ideia de restauração no dealbar do séc. XIX. Embora no seu formulário estes documentos sugiram uma autoria militar, um avultado número de proclamações foram redigidas por bispos e outras dignidades da igreja universalmente reconhecidos como «santos pastores» e virtuais depositários da «sacro-santa cruz e da espada» $\left({ }^{162}\right)$.

(i«) in Fr. Manuel do Cenáculo Villas Boas, ob. cit., pp. 30-32.

(ie2) Proclamação de José de Mello Pereira Corrêa Coelho, capitão do Senado da Câmara do Porto, s.d., in Collecção de Proclamações e Editaes, fl. 16. 


\section{Revoltas e Ideologias}

É uma constante, nestes textos, a evocação a um pacto sagrado e inviolável de obediência e fidelidade à monarquia de direito divino, a única forma de governo legítimo dos povos. A heroicidade popular é exaltada, dentro de certos limites, na medida em que surge como sinal exterior desse compromisso (16S).

Da evocação jusdivinista do poder passa-se insensivelmente à imagem do reino de Portugal como jóia do património divino, herança conservada e mantida pela monarquia fidelíssima. $\mathrm{Na}$ presença de um «tirano intruso» a comunidade, depositária em última instância do poder político derivado de Deus, tinha o direito de resistir. A revolta e/ou a rebelião tornava-se, a esta luz, não só justa como imperativa. Estas teses de vinculação escolástica proclamadas indistintamente pela hierarquia eclesiástica e civil revelam bem a linha de continuidade que atravessa o pensamento político português, particularmente de 1640 a $1808\left({ }^{164}\right)$.

A concepção de exercício do poder que acabamos de esboçar afigura-se-nos dominante nestes documentos de ampla difusão. Em contrapartida, ao nível jurídico-político e canonístico-teológico a obra de José Morato (165) parece denunciar um acentuado apego a teorizações de lastro ainda mais conservador. O autor das Dissertações Anti-Revolucionárias afirma, sem rodeios, a supremacia do poder espiritual sobre o temporal; considera em termos absolutos a infabilidade papal; e não admite que a comunidade possa resistir, em circunstância alguma, à autoridade que represente o poder emanado de Deus. Esta obra, quer pelo seu carácter ultramontano e papista, quer porque apontava tendencialmente para o não reconhecimento da legi-

(163) Idem, fis. 16, 19, 22; Cf. J. Acúrsio das Neves, $A$ voz do Patriotismo na Restauração de Portugal, E Hespanha, Lisooa, 1808, p. 13 e Falia da Nação Portugueza dirigida nas presentes circunstancias aos Illustrissimos e Excelentíssimos Senhores Governadores destes Reinos, Lisboa, 1809, pp. 3-4.

(164) Sobre a fundamentação do poder político na época da Restauração vide Luis Reis Torgal, Ideologia e Teoria do Estado na Restauração, vol. II, Coimbra, 1982, cap. I.

(163) José Morato, Dissertações anti-r evolucionárias, Lisboa, 1810. Na dissertação II do cap. V pode ler-se: «o poder dos Soberanos vem de Deus. IToda a potestade vem de Deus; porque não ha potestade que dele não venha; $\mathrm{e}$ assim as que ha, são ordenadas por Deus; e daqui vem, que os que resistem à Potestade, resistem à ordenação de Deus, e atraem sobre si a condenação», p. 61. Atribui-se a este autor outra obra que foi igualmente censurada em 1815, Conheca o mundo os Jacobinos que ignora, ou exposição das verdades catholicas, contra os artigos fundamentaes do Systema anarchico dos theologos regalistas do século XVIII, e do Presente. Em quatro folhetos. Londres, 1812. 


\section{Revoltas e Revoluções}

timidade da revolta nacional, foi censurada e impedida de circular.

Mas dizíamos que a revolta ganhava entretanto um sentido imperativo. Vejamos como este aspecto tende a conferir à libertação nacional uma dimensão quase sagrada.

Alegava-se que «a justiça divina não podia consentir.... que uns usurpadores, uns tiranos levassem a sua impiedade ao ponto de se intitularem omnipotentes, usurpando o título que só à divindade pertencia» (166). E que os invasores «na sua arrogância diabólica» ( ${ }^{167}$ ) não só faziam perigar a unidade do Estado como ameaçavam ferir com golpes de morte, isto é com a «sua fatal incredulidade» (168) os atributos da divindade. Daí que a resistência anti-francesa fosse considerada como uma «guerra da Religião e do Estado» $\left({ }^{169}\right)$. A razão de ser desta guerra começara inevitavelmente com a revolução francesa «que aberrando dos princípios da razão e da ordem queria destruir os dois poderes régio e sacerdotal que Deus instituiu para o governo do mundo e pôs como bases fundamentais da sociedade»» $\left({ }^{170}\right)$. A visão ampliada e deformante da revolução de 1789 resulta da perspectiva teológico-jurídica em que se coloca este e outros comentadores contemporâneos. Logo, o produto imediato da revolução seria o ateísmo e o anarquismo, isto é, a negação absoluta de Deus e com ela a impossibilidade de uma ordem política justa e passível de ser respeitada $\left({ }^{171}\right)$.

$C *)$ Vide Proclamação de Aires Pinto de Sousa Coutinho, alcaide-mor do Couto de Cambezes, de 29 de Junho, in Collecção de Proclamações e Editaes, fl. 90.

(167) Vide supra, nt. 140.

(168) Idem, ibidem.

(169) Carta-pastoral do bispo de Aveiro, D. António José Cordeiro, de 13 de Julho de 1808, in Collecção de Proclamações e Editaes, fl. $44 \mathrm{v}$.

$\left({ }^{170}\right)$ Frei Joaquim Soares, ob. cit., II, p. 5.

$\left.O^{71}\right)$ Vale a pena assinalar a confluência de argumentos em torno desta ideia - «Aconteceu a Revolução Francesa em 1789 ainda que anunciada muito tempo antes: destruidas todas as barreiras dos poderes legítimos, e da subordinação; profanada, e violada a religião, único freio, e única consolação dos homens, aniquiladas todas as instituições saudaveis, degradada a justiça, pervertida a ordem, deificado o materialismo, subvertida toda a moral pública e particular» (Ensaio Historico e Politico do Reino de Portugal desde o mez de Novembro de 1807 até o mez de Junho de 1808, Rio de Janeiro, s.d.); «É certo que o sistema dos franceses consiste em não ter religião» (Partidista contra Partidistas, e Jacobinos Praguejados. Dialogo entre um partidarista e um verdadeiro amigo, Lisboa, 1808, p. 3); Cf. J. Acúrsio das Neves, Manifesto da Razão contra as usurpações Francezas offerecidas à Nação Portugueza, aos soberanos e aos povos, 


\section{Revoltas e Ideologias}

Os desígnios imperialistas de «uma nação sem fé e sem lei» (172) adquirem, no contexto da mentalidade ultramontana, a aparência de uma ofensiva infiel, coincidente da sua essência com a imagem que se forjara do poderio muçulmano na era da reconquista, e do ímpio indígena no período da expansão e colonização. Daí a revivescência mitigada de um certo espírito de cruzada e o retomar constante de uma tradição de hegemonismo espiritual e católico que criava filiação e missão de grandeza. Ideia que se depreende deste passo de ressaibo épico: «A nação portuguesa, aquela mesma nação que por entre espantosos perigos, por mares nunca dantes navegados, soube levar a distantes regiões do mundo o nome de seus monarcas, a sua glória, a qual não cabia em curto espaço e a verdade da religião que perfeitamente professava, vem agora, novamente reunida pelo amor e pela fidelidade, jurar ante o trono de V. A. R. nas presentes circunstâncias: morrer ou vencer pela pureza da sua Santa Religião, pela sagrada pessoa de V. A. R., pela indemenidade da sua pátria e pela conservação de seus direitos» (173). Ou ainda por esta outra alusão de carácter providencialista: «Portugal parece ter sido destinado pelo Todo Poderoso para propagar o Evangelho e arvorar o estandarte da St. ${ }^{a}$ Cruz» (174). Evocações como estas caucionam a identificação generalizada do francês ao mouro e ao ímpio ou permitem mesmo colocá-lo, pelo seu alegado grau de ateísmo, para além deles. Assim, a propósito das desvastações que o exército de Junot causara no país, Daniel Rodrigues da Costa comentava: «Se os mouros aqui tornassem / outro tanto não fariam» $\left({ }^{175}\right)$. Paralelismo que jorra com frequência da literatura panfletária desta época.

Lisboa, 1808, pp. 9 e 11; Os pedreiros-livres $e$ os aluminados que mais propriamente se deverião denominar os tenebrosos. De cujas seitas se tem formado a pestilencial irmandade, Lisboa, 1809.

(172) José Daniel Rodrigues da Costa, Surriada a Massena em Portugal, e encontro de duas rivaes no palacio imperial de França, Lisboa, 1811, p. 8.

(173) Falia da Nação Portugueza...., p. 3.

(m) «proclamação recitada no dia 14 de Julho do corrente ano de 1808 pelo Desembargador Francisco José de Miranda Duarte de Azere», in Collecção de Proclamações e Editaes, fl. 119; e Proclamação de Manuel Jorge Gomes de Sepúlveda, governador das armas da província de Trás-os-Montes, de 21 de Junho de 1808, Idem, fl. 58; cf. Acúrsio das Neves, $A$ voz do Patriotismo...., p. 14.

(iis) Proteç̧ão à Franceza, Lisboa, 1808, p. 8; Cf. do mesmo autor, Embarque dos apaixonados dos francezes para o hospital do mundo, ou Segunda parte da protecção à franceza, s.l., s.d., Sobre o sentido irónico da palavra protecção, na época, veja-se A. C. Pires de Lima, As Invasões Francesas na tradição oral e escrita. Subsídios, Separata da Revista Lusitana, vol. XXIII, Porto, 1922. 


\section{Revoltas e Revoluções}

Eis outro exemplo: «Roubando a Deus seus cultos: / Só propagando bárbaros insultos: / Tratando os sacramentos / Quais ímpios réus em hórridos tormentos / Mandais que a missa seja / Vedada já nas casas, já na Igreja / Estas leis não admiram / Que os brutos moiros nunca missa ouviram. / $\mathrm{O}$ clero perseguido / Foi na França, em geral, preso e punido / Que o Maome, o Pirata / Ao que moiro não é persegue e mata» $\left({ }^{176}\right)$.

Estas expressões, cujo significado imediato sugerem a força e extensão da mentalidade tradicionalista católica, estão na origem da «cruzada contra-revolucionária» que ciclicamente interceptou o curso do liberalismo oitocentista. Para além disso, este espírito potenciado germinalmente entre 1808 e 1814 contou durante o miguelismo com idênticos suportes sociais. É a mesma aliança histórica de grupos sociais antagonistas em defesa da legitimidade monárquica absolutista que, à partida, parece caracterizar a complexa teia de adesões ao regime de D. Miguel.

A temporalidade ideológica que aproxima 1808 de 1823 pode ainda aferir-se pela persistência do integrisme* teológico político de inspiração tridentina reavivado com a obra de Joaquim José Pacheco e Sousa $\left({ }^{177}\right)$ e retomado pelo clero no campo de mobilização da Vilafrancada ou, também, pelo livre curso que tiveram as ideias de José Morato, particularmente através das Peças justificativas da doutrina do autor do livro intitulado Conheça o mundo os jacobinos que ignora.... publicadas em homenagem do cardeal D. Carlos da Cunha (178).

Da mesma forma, os métodos e processos de depuração ideológica utilizados depois do fracasso do vintismo despontam no período das invasões. A fobia anti-jacobina que atingiu verticalmente toda a sociedade foi poderosamente consciencializada pela institucionalização da prática de delação oculta ou

(1TO) António Joaquim de Carvalho, $\mathrm{Na}$ Restauração de Portugal, libertado do jugo dos francezes. Verdades críticas. Lisboa, 1808, pp. 4 e 5; Cf. João José Pinto de Vasconcelos, Os três tempos ou trabalhos passados, $e$ as alegrias de Portugal, presentes, e futuras, s.l., s.d.. No opúsculo anónimo intitulado Sonhos fantásticos do usurpador Junot, com desesperadas reflexões, que ele mesmo fez ou devia fazer em acordando. Parte I, Lisboa, 1808, admite-se, jocosamente, que Junot só poderia viver tranquilo em Portugal se os portugueses pudessem ser «atraídos por os campos da Mourama», p. 5.

$(\mathrm{m})$ Joaquim José Pacheco e Sousa, O concílio tridentino vindicato ou demonstração critico-canonica da genuina inteligência do mesmo Sagrado Concílio no cap. VIII, sess. XIV, Lisboa, 1808; Cf. Graça e J. S. da Silva Dias, ob. cit., vol. I, t. II, pp. 847-850.

(178) A obra, Conheça o mundo os Jacobinos que ignora...., foi censurada em 1813, no ano seguinte ao da sua publicação. $E$, portanto, da maior relevância a sua divulgação em 1823. Vide Inocêncio Francisco da Silva, Diccionario Bibliographico Portuguez, t. V, pp. 77-79. 


\section{Revoltas e Ideologias}

anónima instituída pela Intendência Geral da Polícia, iniciativa que permitiu forjar um número avultado de suspeitos.

Mau grado o exagero dos contemporâneos em relação aos efectivos detractores do regime, em grande parte ditado pelo crescendo liberal espanhol, conheceram-se inequívocas manifestações de conotação liberal e constitucional logo em 1808.

\section{Os afrancesados e o projecto constitucional de 1808}

7.1, Um dos momentos mais mobilizadores para as élites pré-revolucionárias portuguesas, situa-se em Portugal, como em Espanha, logo em 1808.

O que caracteriza, por oposição aos liberais espanhóis de 1808-1814, a prática política do círculo liberal português é a ausência de um modelo ideologicamente magnético e catalizador de um processo revolucionário. De expressão numérica inferior, a facção liberal pulverizou-se fundamentalmente em três grupos. $\mathrm{O}$ mais significativo permaneceu silencioso e participou por fim, sem consciência das consequências práticas desse empenhamento na restauração da independência nacional. Inserem-se no grupo: Manuel Fernandes Tomás, José da Silva Carvalho, Francisco Simões Margiochi, Manuel Borges Carneiro, Nuno Pato Moniz, João Bernardo da Rocha Loureiro, Agostinho José Freire, Mousinho da Silveira e outros nomes conhecidos do regime liberal após a revolução vintista. Esboçaram-se, para além desta, duas tentativas de mudança do status político, tipificadas em torno de dois modelos distintos: o monárquico parlamentar que, como já observámos, cauciona a proclamaçã̃o, em Junho de 1808, da ala militar da Junta Provincial do Porto e outra, de vinculação ao regime autocrático napoleónico de expressão reformista e liberal proposto pelos afrancesados, em Maio de 1808.

A maçonaria, desde 1804 liderada pelo $1 .^{\circ}$ directorio do Grande Oriente Lusitano, não participou directamente como estrutura organizada, em qualquer destas movimentações.

A recepção pronta que um grupo de mações proporcionou ao general francês, no seu percurso de Abrantes para Lisboa, foi seguramente condicionada pelas ligações que Junot anteriormente mantivera, durante a sua enviatura diplomática, em Lisboa, com elementos da maçonaria lusitana $\left({ }^{179}\right)$. A grande

(179) «O general diz que estes habitantes de representação eram pedreiros livres...., bem parece que tem mantido com eles relações desde a época da sua embaixada em Lisboa», (Carta de Thiébault para Clark, de 1 de Dezembro de 1807, transcrita por C. A. de Magalhães Sepúlveda, ob. cit., vol. XII, p. LXXXII, nt. 1). 


\section{Revoltas e Revoluções}

liberalidade demonstrada pelo governo de protectorado francês para com alguns mações presos, inscreve-se num plano manipulators mais vasto. A libertação de José Ferrão de Mendonça, prior da igreja dos Anjos, de António José Rodrigues de Almeida Ferreira, prior da igreja de S. Jorge, e de José Joaquim Vieira Couto, professor de matemática, naturalmente que agradou à Ordem $\left({ }^{180}\right)$. Logo se revelou, sem rodeios, a existência de uma facção pró-francesa no seio da irmandade. O próprio grão-mestre, Sebastião José de Sampaio Melo e Castro se dispôs a ceder o seu lugar ao general francês, sendo neste desígnio apoiado, entre outros, pelo venerável da loja Concórdia, António Coutinho Pereira de Seabra da Silva.

A mais moderna e exaustiva investigação neste domínio revela que a cisão entre o grupo pró-francês e a ala que por comodidade chamamos brigantina, dificultou no interior da maçonaria uma acção política mais enérgica. O Grande Oriente Lusitano assumiu tardiamente uma posição reservada e de grande distanciamento em relação à difícil e caótica situação do país. «Todos os indícios sugerem que as lojas procuravam apagar-se publicamente» ${ }^{181}$ ). $\mathrm{O}$ que não quer dizer que alguns mações não tivessem integrado correntes de opinião genuinamente afrancesada ou, em contrapartida, de conotação patriótica. Se duvidamos da existência de um «Instituto Luso-Maçónico Imperial» (182), em 1808, admitimos, pelo menos, que o projecto chegou a ser aventado por alguns mações. É também significativo que o Conselho Conservador de Lisboa, sociedade secreta criada em 5 de Fevereiro de 1808, após a demarcação do Grande Oriente Lusitano do junotismo, contasse entre os seus 300 membros, com alguns convictos mações como o próprio grão-mestre Sebastião José de Sampaio de Melo e Castro, André da Ponte Quental da Câmara e José Máximo Pinto da Fonseca Rangel ( $\left.{ }^{183}\right)$. Este grupo «de conspiradores pacatos e

(iso) António Ferrão, ob. cit., pp. 19-20, 25 e 29; e Georges

Boisvert, ob. cit., p. 83, nt. 119.

(1S1) Graça e J. S. da Silva Dias, ob. cit., vol. I, t. II, p. 510.

(182) Designação utilizada na "Notícia da Biblioteca Volante ou Collecção dos livros novamente dados à luz e dos que estão no prelo, com os nomes dos seus escritores, e o prospecto das obras: muito interessante e util aos patriotas francezes e aos verdadeiros portuguezes» in Policia Secreta dos ultimos tempos do reinado do Senhor D. João VI, e sua continuação até Dezembro de 1826, Lisboa, 1953, p. 457.

(183) S. J. da Luz Soriano, ob. cit., segunda ephoca, t. I, pp. 716-717; Inocêncio Francisco da Silva, Diccionario Bibliographico Portuguez, vol. V, p. 70; Georges Boisvert, ob. cit., pp. 79-80, nts. 106 e 107. 
prudentes $\left({ }^{184}\right)$, que reabsorveu fortes contingentes maçónicos, era essencialmente constituído por militares, magistrados e eclesiásticos. Da sua acção, em 1808, ressaltam os esforços empreendidos para a manutenção da ordem em Lisboa.

Acorrentados pela inércia deste e de outros órgãos e instituições políticas e temerosos quanto à evolução e desfecho dos motins protagonizados pelos de mais baixa condição, os corifeus do liberalismo constitucional acabaram por trilhar a via do compromisso bonapartista, a mais imediata para a materialização de um vasto programa de reformas institucionais e económicas. Coligados com sectores da intellegentsia iluminista, espreitaram a oportunidade de forçar a política napoleónica em relação a Portugal, a inflectir no sentido de um constitucionalismo moderado e musculado que desse expressão política à desestruturação do antigo regime e facilitasse um ordenamento social de predominância burguesa.

Estes afrancesados - «que notando as insuficiências da situação descriam no príncipe, e sonhavam com uma regeneração governativa [e] com a criação de um estado constitucional» $\left({ }^{185}\right)$ — apresentam fortes traços de identificação com o poderoso grupo de afrancesados espanhóis que secundaram a escolha de José Bonaparte para o trono espanhol, tomaram parte na deputação geral e aplaudiram a constituição de Baiona promulgada pelo imperador, em 6 de Junho de 1808. A este propósito, é sintomático que os nossos afrancesados constitucionalistas só se tenham feito ouvir, em finais de Maio, quando o processo tendente à convocação do congresso espanhol para a elaboração e ratificação da Constituição estava já concluído, conforme noticiava a Gazeta de Madrid de 24 de Maio (186). Em termos programáticos parece-nos, no entanto, que os afrancesados portugueses levaram mais longe as suas aspirações regeneradoras.

Para além da confirmação das intenções revolucionárias de Napoleão para com o país de Godoy, teve também grande impacto para o desencadear da conspiração afrancesada, a alte-

(m) Francisco da Fonseca Benevides, No tempo dos francezes, Lisboa, 1908, p. 143.

(185) Parece-nos, neste ponto, convincente a tipología que Luis A. de Oliveira Ramos, apoiado na análise de um contemporâneo, nos fornece sobre os afraneezados de 1808. Os afrancesados do Porto, Porto, 1982, Sep. da Revista de História, vol. III, p. 6; Cf. do mesmo autor, O Porto e as Origens do Liberalismo. Subsídios e Observações, Porto, 1981.

(186) Miguel Artola, Los Afrancesados, Madrid, 1976; La Burguesia Revolucionaria (1866-1869), Madrid, 1973. 
ração formal das cláusulas do Tratado de Fontainebleau. A salvaguarda da indivisibilidade do país, garantida no encontro de 27 de Abril em Baiona entre a deputação portuguesa e o imperador, implicava a exigência da cedência da coroa portuguesa a um monarca da eleição do imperador e deixava subentendida a possibilidade do novo governo se reger também por uma constituição política $\left({ }^{187}\right)$. Assim, na sequência das conversações de Baiona, o imperador cuidadosamente auscultava o general Junot - «Y-a-t-il inconvenient de faire publier le Code Napoléon en Portugal?» $\left({ }^{188}\right)$.

A timorata resposta do seu interlocutor em Lisboa $\left({ }^{189}\right)$,

(18T) «tfTodos.... os vínculos sociais deviam ser rotos, tudo devia acabar, não era dizia-se Instituições Liberais», (Exposição ao Príncipe Regente cit., por L. A. Oliveira Ramos, «D. Francisco de Lemos e a Deputação a Baiona», Estudos de História de Portugal - sécs. XVI-XX, vol. II, Homenagem a A. H. de Oliveira Marques, Lisboa, 1983, p. 283); Graça e J. S. da Silva Dias, ob. cit., vol. I, t. II, pp. 496-497.

(188) Carta de Napoleão de 15 de Maio de 1808, cit. por Albert Silbert, Autour de Francisco Solano Constando, Paris, 1950, Sep. de Bulletin des Études Portugaises, p. 13.

(iso) (Tentando salvaguardar os interesses das classes dominantes, Junot advertia: «Je crois qu'il y aurait de grands inconvénients à publier les differents codes de lois en ce moment, les lois de ce pays sont trop différents des nôtres, particulièrement pour ce qui regarde les heritages. Il me faudrai ici quelques hommes forts sur cette matière qui puissent débrouiller l'organisation legislative actuelle et présenter à $V$. M. les inconvénients ou le bénéfice de la promulgation des nouveaux codes, ou indiquer les changements que les localités et le génie du pays doivent apporter.... prévoyant bien les intentions de V. M., j'avais demandé la traduction de ces differentes codes: le code de procedure civile est déjà à l'impression; le code de commerce est traduit; on s'occupe de traduire les autres, et je les ferais imprimer.... et répandre dans le pays, les jurisconsultes feront leurs reflexions. Quelquer uns s'y attelent déjà» (Carta a Napoleão de 24 de Maio de 1808, cit. por C.A. de Magalhães Sepúlveda, ob. cit., vol. XII, p. 201). Todo o processo que envolve a escolha do tradutor do código civil de 1804 não é ainda suficientemente claro. É pelo menos surpreendente que entre a sugestão do imperador (de 15 de Maio), no sentido de se encontrar tradutor para o código e de o fazer publicar, e a resposta do general Junot que dava a referida obra já traduzida e em vias de publicação, medeie pouco mais de uma semana. Donde se pode inferir que a ideia de imposição do código é anterior à proposta de Napoleão. A sua tradução foi provavelmente iniciada e elaborada antes de Maio e, muito embora, Junot pretenda reclamar essa iniciativa, nenhum documento o comprova. Pensamos antes que o projecto inicial e a sua concretização se inscrevem na aç̧ão subterrânea desenvolvida pelos constitucionalistas até aquela data. Senão vejamos: não parece crível que Junot desaconselhando inteiramente e com razões fundadas em argumentação sólida a vigência dessa compendiação legal tenha simultaneamente impulsionado a sua tradução. Quando tentou encontrar tradutor, então sim, deparou com a obra já concluída ou em fase 
não era de molde a dissuadi-lo das vantagens imediatas do seu intento. Por isso, pouco depois, reafirmava: «Je verrai avec plaisir que le Code Napoléon soit imprimé et publié» (190). Esta «obsessão» aliada à proposta de secularização de metade dos bens dos conventos, obedecia à imperiosa necessidade de realizar receitas avultadas que diminuíssem o déficit do governo francês e cobrissem as despesas da guerra. Mas os afrancesados constitucionalistas logo visionaram de forma dilatada estas circunstanciais disposições napoleónicas. Neste contexto, as esperanças regeneradoras deste punhado de homens tornavam-se plenamente fundamentadas.

7.2. Entre os afrancesados constitucionalistas pontuavam, em primeira linha, os herdeiros da tradição iluminista de influência francesa e cameralística alemã, filiação doutrinal dominante em Ricardo Raimundo Nogueira e Simão Cordes Brandão e Ataíde, ambos professores na universidade conimbricense. Dos restantes elementos conhecidos, sabe-se que predominavam personalidades ligadas aos quadros da magistratura - o desembargador Francisco Duarte Coelho e os juízes de fora Bento Pereira do Carmo e José Joaquim Ferreira de Moura (191). Importa salientar que tanto Duarte Coelho como Pereira do Carmo faziam parte da família pedreiral $\left({ }^{192}\right)$.

adiantada. $O$ trabalho foi elaborado por um jovem advogado que ao tempo, dispunha de autorização para advogar na Casa aa Suplicação de Lisboa, José Joaquim Ferreira de Moura. Ao mesmo trabalho se associou outra figura grada da Casa da Suplicação, o desembargador Francisco Duarte Coelho que concorreu para a finalização da obra e sua divulgação redigindo um relatório que acompanhava aquela publicação.

(100) Carta de Napoleão a Junot, datada de 3 de Junho, cit. por Albert Silbert, ob. cit., p. 14. Apesar do processo político afrancesado se encontrar, em Espanha, em fase mais adiantada - lembremos que, a este tempo, faltava apenas ratificar a Constituição de Bayona - os afrancesados portugueses conseguiram ver publicado o código civil de $1804 \mathrm{com}$ alguma anterioridade em relação à $1 . .^{\mathrm{a}}$ versão castelhana da mesma obra. Veja-se, Código Napoléon con los variationes adptadas por el cuerpo legislativo del dia 3 de Septiembre de 1807, Madrid, 1809, En la Emprenta da hira de Hare, Cf. C. A. de Magalhães Sepúlveda, Diccionario Bibliographic o da Guerra Peninsular, vol. 1. ${ }^{\circ}$, Coimbra, 1924, p. 237.

(m) Em Setembro de 1804, foi nomeado juiz de fora de Aldeia Galega. (A.N^T.T., Chancelaria de D. Maria I, liv. 73, fl. 158 v.). Em 1807, contava-se entre os advogados com «portaria para advogar na Casa da Suplicação» em Lisboa (Almanach do Anno de 1807, p. 223).

(192) Bento Pereira do Carmo foi iniciado em 1800 e pertenceu à loja Fortaleza de Lisboa. Vide Miguel António Dias, Annaes e codigo dos pedreiros-livres em Portugal, Lisboa, 1853, pp. 161-163. Sobre Francisco Duarte Coelho veja-se Graça e J .S. da Silva Dias, ob. cit., vol. I, t. II, nt. 2 da p. 801 e p. 802. 
Tiveram igualmente papel de relevo na dinamização do grupo, para além do médico Gregorio José de Seixas, dois franceses, o oficial Henri Carrion d'Espagne Nisas e o influente industrial Timóteo Lecussan Verdier.

Temos fortes razões para acreditar que este núcleo de afrancesados contava com uma rede mais vasta de colaboradores e apoiantes. É nesse sentido que aponta o testemunho de Carrion Nisas - «Nous avions pour nous tout le parti des hommes qui se portaient pour disciples du marquis de Pombal et c'était la partie la plus éclairée de la noblesse et du haut tiers-état.

Nous avions pour nous tout le parti des jeunes magistrats et la moitié de l'Université de Coimbra, qui voulait absolument introduire tous les codes (deux ont été traduits au Portugais, j'y ai travaillé mois-même à la prière des traducteurs, celui de la procédure est imprimé). Nous avions pour nous tous les bourgeois et négociants opprimés par la noblesse la plus vide et la plus ridicule de l'univers. Nous avions pour nous les créanciers, contre les débiteurs, dont les majorats, multipliés à l'infini, favorisaient la mauvaise foi. Nous avions pour nous, enfin, les laboureurs, dont la condition est affreuse sous la rapport du fisc et des seigneurs, et le clergé séculier qui est misérable à côté des moines» $\left({ }^{193}\right)$.

Colocando a questão do afrancesamento num piano ideal, isto é, meramente ideológico, Carrion Nisas, transfere a lógica da revolução francesa para a textura social portuguesa produzindo, consequentemente, uma apreciação algo exagerada da real teia de adesões ao programa revolucionário constitucionalista. Ressalvado este aspecto, tudo indica que os afrancesados da capital não estavam sós.

Sabe-se através de uma informação lavrada pelo intendente geral da Polícia, Lagarde, em 28 de Maio de 1808, que o industrial Lecussan Verdier desenvolvia uma intensa propa-

(1w) Cit. de Louis Dermigny, "Carrion-Nisas et 1'Espagne», in Fédération Historique du Languedoc Meditteranéen et du Roussilon, $X X I X^{e}$ Congrès, Mendo, 1955, p. 143. De facto, parece confirmar-se a existência de um grupo de estudantes afrancesados na Universidade de Coimbra. O corregedor de Tomar, em carta datada de 28 de Junho para o intendente Lagarde, dá-nos conta de um grupo «de étudiants de Coimbre qui se sont réfugiés à Thomar et ont annoncé que plusieurs hommes armés se sont présentés dans cette ville, la nuit du 23 au 24 de ce mois et ont soulever les habitants, ainsi que ceux du voisinage, Les individus n'ont pu donner d'autres détails, parce qu'ils se sont retirés le principe du tumulte», in Antonio Ferrão, ob. cit., p. 441. 
ganda revolucionária na província $\left({ }^{194}\right)$. As representações dirigidas a Junot pelas câmaras de Tomar, Ançã e Valença confirmam que o movimento transpôs com enorme rapidez as fronteiras da capital, o que permite, para alguns casos, pensar numa acção previamente concertada e bem urdida. A proclamação da comarca de Ançã da autoria do mação e liberal Bento Pereira do Carmo é bem a réplica provincial mais perfeita da súplica divulgada em Lisboa, a 26 de Maio (195). Elementos da magistratura de outras comarcas - Porto, Setúbal, Alpedrinha, Torre de Moncorvo, Penafiel e Ponte de Lima - expressavam igualmente o seu apoio ao programa regenerador afrancesado subscrito pelo núcleo de Lisboa (196).

A um nível mais restrito, não é fácil divisar nas denúncias públicas, nas listas de «partidistas» afixadas em locais de maior afluência de gente e na literatura panfletária que corria anónima e até manuscrita como por exemplo, a Gazeta d'Almada, indicações seguras de conluio com os afrancesados constitucionalistas. Sob a acusação genérica de partidistas, os contemporâneos amalgamavam vários sectores de opinião afrancesada. Da lista de partidistas que apareceu afixada em Setembro de 1808 «na esquina do primeiro quarteirão indo do Rossio da parte direita...» $\left({ }^{197}\right)$, pudemos confirmar que Francisco Duarte Coelho é o único elemento conhecido mencionado. A par do desembargador da Casa da Suplicação, são também visados: José da Costa Simas $\left({ }^{198}\right)$, José Diogo de Mascarenhas

(m) Cf. Relatório $n .^{\circ} 17$ do intendente Lagarde para Junot, in António Ferrão, ob. cit., pp. 360-361 e 415-417. O oficial Carrion Nizas mostrou-se igualmente diligente na mobilização de sectores da administração provincial para a causa constitucional. Uma petição assinada percorreu «plus de vingt quatre communes de plus considerables du Portugal». Albert Silbert, Autour de F Solano Constâncio, p. 64).

(iss) o Conimbricense, n. ${ }^{\circ} 2852$, de 24 de Novembro de 1874. Cf. Francisco Augusto Martins de Carvalho, Guerra Peninsular. Notas, episódios e extractos curiosos, Coimbra, 1916, pp. 38 e ss.

(19e) Cf. Documentos publicados por C. A. de Magalhães Sepúlveda, ob. cit., vol. XIII, pp. 409-410 e Antonio Ferrão, ob. cit., p. 390. $\left({ }^{197}\right)$ Costa Neves, A Traição de Gomes Freire, Lisboa, 1935, pp. 518-522, Cf. José Daniel Rodrigues da Costa, Conversação Nocturna das Esquinas do Rocío de Lisboa, Lisboa, 1812.

(198) «L'activité professionnelle de Simas et sa notoriété faisaient de lui une personalité éminente de la bourgeoise lisbonnaise. Il appartenait évidement à cette catégorie de Portugais aisés, cultivés, réceptifs à l'esprit des 'Lumières'». (Georges Boisvert, ob. cit., p. 55). $O$ conhecido afrancesado viria, em Setembro de 1810 , a ser preso e deportado para os Açores conjuntamente com cerca de quarenta personalidades conhecidas e afectas à maçonaria e (ou) opinião liberal. 
Neto e seu filho $\left({ }^{199}\right)$ e João António Rodrigues Ferreira $\left({ }^{20}\right)$ (mais conhecido por Tintim), homens de formação jurídica e, ideologicamente próximos do projecto constitucional de Maio de 1808.

Num outro documento intitulado Noticia da Biblioteca Volante... ou Collecção dos livros dados à luz e dos que estão no prelo, com os nomes dos seus escritores, e o prospecto da\& obras, muito interessante e util aos patriotas jrancezes e aos verdadeiros portuguezes, destinado a publicar-se na jocosa e anti-afrancesada Gazeta á!Almada (201) reúnem-se títulos de obras respeitantes à jurisprudência, isto é, «tudo quanto pertence ao direito civil, eclesiástico, e sobretudo constitucional, em que florescerão muitos dos nossos magistrados e até não magistrados» (202), Ciências Naturais, História, Economia e Política, «tema universal de todos os homens no estado actual das luzes» $(203)$.

Não cremos que tenham sido publicadas obras tão volumosas como as Memórias Constitucionais em 12 volumes atribuídas a Ferreira de Moura. A nossa incredulidade baseia-se na manifesta impossibilidade de num lapso de oito ou nove meses, terem sido redigidos, aprontados e dados a público, para além desta suposta obra, outros 98 títulos, a maior parte em varios volumes. O que coloca desde logo o problema da falsidaae ao aocumento. Mas também os documentos forjados, com

(199) José Diogo de Mascarenhas Neto, desembargador da Casa da Suplicação e conselheiro vereador do Senado de Lisboa em 1807, colaborou electivamente com o governo de protectorado francês. Em 1810, suspeito de pedreiro-livre e acusado de inconfidência, é também incluído no grupo dos sexembrizados. No ano da sua deportação, seu filho, João Diogo de Mascarenhas Neto, ao serviço de Massena em 1810, era supliciado em Lisboa, no largo do Cais do Sodré, sob a acusação de traição. Exilado em França, funda em 1818, com Francisco Solano Constâncio e Cândido José Xavier, os Annaes das Sciendas, das Artes e das Letras.

$\left({ }^{20}\right)$ João António Rodrigues Ferreira, fazia parte dos quadros da magistratura ao tempo da $l^{a}{ }^{a}$ invasão francesa. A acusação de partidista confirma-se pela sua inclusão na Notícia da Biblioteca Volante. Mais tarde, da Lista Confidencial ou Secreta dos Ministros dos principaes Tribunaes, e Dezembargadores das Relações de Portugal, notas de bõa ou má opinião publca -1830 a 1831. Consta a seguinte informação deste desembargador do Conselho Ultramarino: "além de pedreiro, foi sempre um refinado ladrão, receptador de furtos; e que já em 1808, mandara um plano para Paris para entrega, ou tomada do Reino, que foi apanhado pelo capitão mór de Portalegre». (B.G.U.C., Ms. 3139, fl. 4 v).

C201) Vide supra.

$\left.C^{2}\right)$ Idem.

(**) Idem. 
toda a prudência de análise que exigem, merecem a nossa atenção. Os indivíduos a quem são imputadas as obras existiram, o que faz com que a indicação de autoria obedeça a uma intenção claramente malévola e persecutória. E não foi sem um conhecimento do que pensavam e planeavam os seus presumíveis autores que se forjou esta relação abreviada. A prova disso, é a indicação de membro da constituição de Varsóvia que acompanha os nomes de Ferreira de Moura, Gregorio José de Seixas, Filipe Ferreira de Araújo e Castro, Francisco Teixeira R. de Carvalho, José Nunes e Francisco Duarte Coelho. A rotulação corresponde, como veremos mais adiante, ao modelo de Constituição que inspirou a súplica destes afrancesados dirigida a Junot, antes da partida da deputação da Junta dos Três Estados que a levaria à presença de Bonaparte em Baiona no mês de Junho.

A imagem de uma intensa actividade editorial orientada para a divulgação do ideário de suporte à «Regeneração da soberania e da administração portuguesa» (204), que se colhe da leitura deste documento, ainda que duvidosa, sugere que o afrancesamento por esta via, das classes médias, potencial base de apoio de um bonapartismo constitucional, não escapou às preocupações da vanguarda liberal afrancesada de 1808 .

7.3. O programa dos afrancesados, só exequível no horizonte de uma uniformização constitucional coerente e adequada às premissas confederativas da política continental de Napoleão, contendia com as mais sólidas e duradoiras estruturas do «Portugal Velho». O paradigma da confederação renana aliado ao modelo de dominação francesa no grão-ducado de Varsóvia consubstancia claramente o projecto regenerador de 1808 . O hegemonismo napoleónico quer na fórmula confederativa quer na de sistema familiar, revelara-se tanto em Nápoles e Piemonte como no reino de Vestefália, Grão-ducado de Berg e até na Holanda, portador de amplas e profundas transformações sociais e políticas. Dos escombros de velhos reinos de tradição feudal e absolutista erguiam-se sob a tutela imperial francesa, novas nações onde a unidade e indivisibilidade da soberania era respeitada pelos poderes tripartidos do Estado.

A miragem da incorporação do estado satélite mais ocidental e atlântico da Europa no sistema confederativo imperial, mesmo que formalmente materializado pelo elo dinástico napoleónico, tal como acontecera em Espanha, preenchia o espaço de expectativa e de ilusão dos nossos afrancesados. A abdicação

(204) Idem. 


\section{Revoltas e Revoluções}

da dinastia de Bragança, isto é, de uma realeza de direito divino e a sua substituição por uma coroa fundada no mito monárquico absolutista, mas em contrapartida herdeira de uma tradição liberal, a da revolução francesa, preludiava, na lógica destes políticos, a possibilidade singular de uma experiência regeneradora, in vitro, pela imposição de fora para dentro de um regime constitucional moderado que «anestesiasse» a brutalidade da transição do «antigo regime» para a nova ordem liberal burguesa.

A intervenção napoleónica, encarada como praxis de um reformismo autoritário esclarecido faria reviver no entendimento dos homens de oito a continuidade histórica interrompida entre o período pombalino e a governação do Portugal oitocentista. Por isso, Carrion Nisas, como já vimos, dava como certo o apoio de «tout le parti des hommes qui se portait pour disciples du marquis de Pombal» (205).

Mas se o programa afrancesado, por um lado, substanciava as aspirações da ala reformista ilustrada, por outro, condensava as premissas essenciais do pensamento liberal. $\mathrm{O}$ melhoramento da administração pública desembocava numa concepção radicalmente diferente de Estado, a racionalização da vida social conjugava a separação do Estado da sociedade civil pela imposição do princípio da igualdade de todos os cidadãos perante a lei, e o acesso à propriedade fundiária operava-se a partir do desmantelamento da estrutura senhorial fundiária. $\mathrm{Na}$ sua incomplitude e pelo seu teor francamente moderado o programa afrancesado traduz bem a confluência de dois horizontes ideológicos complementares — o de um Ricardo Raimundo Nogueira, figura «burocrático-político-intelectual» influente em todas as tentativas posteriores de modernização das estruturas institucionais do Estado Absoluto (206) e o de um José Joaquim Ferreira de Moura, ou até de um Bento Pereira do Carmo, convictos e intransigentes liberais no período vintista.

$\mathrm{O}$ modelo constitucional sugerido a Junot conjugava assim, $\mathrm{o}$ respeito pelos direitos individuais, a universalidade das normas de direito público, o princípio da divisão tripartida de

$\mathrm{C}^{206}$ ) Vide supra.

(206) António Manuel Hespanha, «O projecto institucional do tradicionalismo reformista: um projecto de constituição de Francisco Manuel Trigoso de Aragão Morato (1833)», in O Liberalismo na Península Ibérica na primeira metade do século XIX, vol. I, Lisboa, 1981, p. 74. 


\section{Revoltas e Ideologias}

poderes, a modernização das estruturas administrativas, judiciais e fiscais do aparelho de estado e a destruição da feudalidade $\left({ }^{207}\right)$.

No plano político, afirmação do princípio da divisão tripartida de poderes acabava por ser cerceada pela admissão e concurso do executivo na elaboração da lei. Apelava-se à acção esclarecida e responsável do ministério e conselho de estado, mas subentendia-se a hipótese do monarca usar discricionariamente do seu poder para dissolver a 2 a $^{\mathrm{a}}$ câmara — ponto expressamente contemplado no modelo constitucional de referência. Da mesma forma que o sistema de representação bicamaral previsto na constituição polaca consignava a supremacia legislativa do senado com prejuízo para a capacidade deliberativa da 2. ${ }^{\text {a }}$ câmara. Daqui resultava uma limitação óbvia ao exercício da soberania e ao direito de representação.

A iniciativa de dotar o aparelho de Estado de um ministério para o ensino e cultura, inspirando-se no dirigismo cultural do $1 .^{\circ}$ Império não deixava de corresponder também a um postulado fundamental da axiomática iluminista - o que tomava a instrução como alicerce da felicidade pública. $\mathrm{O}$ recurso à tradição no que concerne à manutenção da religião católica como credo oficial da «Nação Portuguesa» e à forma de apuramento da representação da $2 .^{a}$ câmara, não diminuia o alcance liberal do enunciado em matéria de direitos e deveres individuais. A tolerância civil e religiosa era salvaguardada, a liberdade de imprensa subentendida, e a igualdade civil respeitada pela aplicação da jurisprudência francesa.

Como já foi salientado, «o Portugal Velho, em termos de estruturas sócio-económicas era posto em causa, pelos princípios da igualdade civil e fiscal, pelo programa de desamortização e de reorganização administrativa, sobretudo pela vigência do código civil, de 1804, que no âmbito das relações jurídicas encerrava o ciclo das estruturas de privilégio herdadas da socie-

(TM) A súplica foi lida pelo juiz do povo, José Abreu de Campos, na sessão de 23 de Maio da Junta dos Três Estados. O documento foi redigido por Gregorio José de Seixas, com a participação de outros liberais numa reunião em que esteve também presente o mesmo juiz do povo, presidente eleito da principal corporação dos ofícios de Lisboa. Cf. História d'El-Rei D. João VI em que se referem os principaes actos $e$ ocorrências do seu governo, bem como algumas particularidades da sua vida privada, Lisboa, 1838, pp. 179-181; e S. J. da Luz Soriano, ob. cit., segunda ephoca, t. I, pp. 212-214. Vejam-se Apêndices I e II deste estudo. 
dade feudal, designadamente o instituto de morgadio, os direitos banais, os dízimos e as servidões pessoais» (208).

De facto a abolição dos vínculos e a supressão de toda a teia de gravames e servidões que oneravam e prejudicavam a exploração da terra, inscrita no manifesto de Maio, era reforçada pela exigência da aplicação imediata do código de Napoleão. Por este meio, se garantia também, a aceleração da transferência da propriedade.

$\mathrm{O}$ primado concedido à agricultura, no conjunto das preocupações regeneradoras da geração de 1808 , assinala o momento de reencontro do país no seu contexto continental. Admitido o corte do elo vital, entenda-se comercial, entre a metrópole e as colónias, impunha-se um aproveitamento óptimo de outros recursos económicos, nomeadamente do sector extensivamente dominante. Consciente deste imperativo, o general Foy asseverava que «par le système continental, la population agricole n’y perdait rien» $\left({ }^{209}\right)$. E, ainda durante a terceira invasão o general Vicent tentava persuadir as hostes afrancesadas remetidas ao silêncio, de que o grande objectivo do governo francês consistía em "changer le génie industriel des portugais et d'en faire de bons agriculteurs, sachant arrocher de leur sol une subsistance certaine, au lieu de celle que leur procurent, d'une manière précaire, leurs rapports commerciaux avec l'Angleterre» $\left(21^{\circ}\right)$.

Duas ordens de prioridades se entrecruzam conferindo ao problema da decadência da agricultura uma feição radicalmente inovadora. A questão desamortizadora beneficia de um preconceito antisenhorialista e a sua concreção com carácter de urgência é tributária de uma perspectiva longa de enquadramento europeu. Logo, o êxito da estratégia continental na apreciação dos constitucionalistas, passava pela reconversão e modernização das estruturas económicas do país. A convicção da ine-

$C^{208}$ ) Graça e J. S. da Silva Dias, ob. cit., vol. I, t. II, p. 491. Cf. Miriam Halpern Pereira, «A crise do Estado de Antigo Regime: alguns problemas conceptuais e de cronologia», Ler História, n. ${ }^{\circ}$, 1983, pp. 3-14.

(209) General Foy, Histoire de la guerre d'Espagne et du Portugal sous Napoléon...., Paris, 1829, t. III, p. 35.

$\left.\mathrm{i}^{210}\right)$ Reflexions sur la situation de Massena près de Lisbonne après l'affaire de Bussaco, in S. J. da Luz Soriano, ob. cit., segunda ephoca, $t$. V, parte 2. a, p. 226 . Ainda nos preparativos da segunda expedição a Portugal, Carrion Nizas, então em Paris, tentava persuadir Napoleão da urgência de uma profunda reforma agrária em Portugal, o que implicava a «abolition des majorats existants, ruinne de l'agriculture et soutien d'une noblesse essenciellement ennemie. Modification de la féodalité et des lois rurales insensés", (Louis Dermigny, ob. cit., p. 113 . 


\section{Revoltas e Ideologias}

ficáeia de uma mudança política de matriz liberal, sem a destruição dos suportes da feudalidade constitui inegavelmente, preocupação dominante no projecto revolucionário de 1808. A acentuação deste problema em oito, contrasta com a conhecida irresolução dos vintistas perante a mesma realidade.

\section{Conclusão}

A coberto de uma anomástica perfeitamente enganadora, a de Revolução- designação constante em quase todos os relatos e comentários coevos sobre movimentos insurreccionáis que alastram por todo o país nos primeiros anos da guerra peninsular - se tem escamoteado ou colocado em plano secundário os aspectos intrinsecamente conservadores subjacentes a essa explosão patriótica. A violência e a maciça participação que caracterizan! as revoltas de Norte a Sul, especialmente em 1808, não bastam para reforçar a consciência deformante dos seus protagonistas melhor colocados, os mesmos que reclamaram e patentearam pública e eponimicamente os méritos da «gesta revolucionária» tal como o fizeram um Sepúlveda ou um Silveira para Trás-os-Montes. Reivindicação que, ao contrário, atesta exemplarmente a ausência de autonomia da acção popular. De facto, na génese e/ou evolução dos tumultos estiveram sempre presentes os senhores locais.

No plano simbólico, a intervenção destes é assinalada, num primeiro momento, por gestos como a destruição pública de editais franceses, o toque a rebate dos sinos das igrejas, o uso ostensivo do tope nacional na lapela ou no chapéu. Gestos de amplo significado e que associados, concomitantemente, a festividades do calendário religioso, de expressiva devoção por parte dos fiéis, ou a outras celebrações sagradas de circunstância, valem como rituais de iniciação à revolta. Os tumultos evoluem com este estigma originário, não sem sobressaltos para as autoridades constituídas, vindo por fim a culminar, à escala nacional, em movimento restauracionista ideologicamente polarizado em torno da aliança do Trono e do Altar.

A realeza, ausente para uns ou encoberta e portadora de uma esperança tipicamente messiânica para outros, sai desta prova de fogo reforçada. Na campanha ideológica em que se empenharam particularmente os eclesiásticos, sobressaem valores e concepções de lastro verdadeiramente ultramontano. A reafirmação da legitimidade da monarquia absoluta e, com ela, a validação histórica da sociedade de "antigo regime», apenas confirmam o peso e a extensão do Portugal Velho nos alvores da era liberal. 


\section{Revoltas e Revoluções}

Paradoxo que encontra também nesta época o seu nascimento com o surgir de um programa constitucional afrancesado, manifestação que evidencia simultaneamente a vitalidade e o isolamento político do pensamento reformista e pré-liberal no decénio que antecede a revolução vintista. Mas se este grupo de afrancesados se comporta como parente pobre do seu congénere espanhol, já as outras formas de afrancesamento em presença no processo político português se revelam, em nosso entender, singularmente distintas. Tudo isto se passa numa conjuntura marcada por uma estratégia atlântica, ponto de chegada da tendência macrocéfala imperial e ponto de partida para o avolumar concomitante de tensões políticas na colónia brasileira e na metrópole europeia. 


\section{DOCUMENTO I}

«Lembrando-se os portuguezes que são de raça franceza, como descendentes dos que conquistaram este bello paiz aos mouros em 1147, e que devem à França, sua mãe patria, o benefício da independencia, que recobraram como nação em 1640, solicitos recorrem, cheios de respeito, á paternal protecção, que o maior dos monarchas ha por bem outorgar-lhes. Dignando-se o immortal Napoleão patentear-nos a sua vontade por orgã̃o dos nossos deputados, quer que sejamos livres, e que nos liguemos com indissolúveis laços ao systema continental da familia europeia; quer que as nações, que compõem esta grande familia, vivam unidas, e que prestes possam gosar das delicias de uma prolongada paz, à sombra de sabios governos, fundados nas grandes bases da legislação e da liberdade maritima e commercial. E por tanto do nosso peculiar interesse, assim como dos outros povos confederados, que a nossa deputação continue a ser junto de sua magestade imperial e real o interprete dos nossos unanimes votos, e que lhe diga: «Senhor! - Desejamos ser ainda mais do que eramos quando abrimos o oceano a todo o universo. Pedimos uma constituição e um rei constitucional, que seja principe de sangue da vossa real familia. Dar-nos-hemos por felizes se tivermos uma constituição em tudo similhante à que vossa magestade imperial e real houve por bem outorgar ao grão-ducado de Varsóvia, com a unica differença de que os representantes da nação sejam eleitos pelas camaras municipaes, a fim de nos conformarmos com os nossos antigos usos.

Queremos uma constituição, na qual, à similhança da de Varsóvia, a religião catholica apostólica romana seja a religião do estado; em que sejam admittidos os principios da ultima concordata entre o Imperio Francez e a Santa Sede, pela qual sejam livres todos os cultos, e gósem da tolerancia civil e de exercido publico:

Em que todos os cidadãos sejam iguaes perante a lei:

Em que o nosso territorio europeu seja dividido em oito provincias, assim a respeito da jurisdicção ecclesiastica, como da civil, de maneira que só fique havendo um arcebispo e sete bispos:

Em que as nossas colonias, fundadas por nossos avós. e com o seu sangue banhadas, sejam consideradas como provincias ou districto, fazendo parte integrante do reino, para que seus representantes, desde já designados, achem em a nossa organisação social os logares que lhes pertencem, logo que venham ou possam vir occupa-los:

Em que haja um ministerio especial para dirigir e inspeccionar a instrucção publica: 
Em que seja livre a imprensa, porquanto a ignorancia e o erro tem originado a nossa decadência:

Em que o poder executivo seja assistido das luzes de um conselho d'estado, e não possa obrar senão por meio de ministros responsáveis:

Em que o poder legislativo seja exercido por duas camaras com a concorrencia da auctoridade executiva:

Em que o poder judicial seja independente, o codigo de Napoleão posto em vigor, e as sentenças proferidas com justiça, publicidade e promptidão:

Em que os empregos publicos sejam exclusivamente exercidos pelos nacionaes que melhor os merecerem, conforme o que se acha determinado no artigo $2 .^{\circ}$ da constituição polaca:

Em que os bens de mão morta sejam postos em circulação:

Em que os impostos sejam repartidos, segundo as posses e fortunas de cada um, sem excepção alguma de pessoa ou classe, e da maneira que mais fácil e menos oppressiva for para os contribuintes:

Em que toda a divida publica se consolide e garanta completamente, visto haver recursos para lhe faze face:

Queremos igualmente que a organisação pessoal da administração civil, fiscal e judicial se ja conforme o systema francez, e que por conseguinte se reduza o numero immenso dos nossos funcionarios publicos; mas desejamos e pedimos que todos os empregados que ficaram fóra dos seus quadros recebam sempre os ordenados, ou pelo menos urna proporcionada pensão, e que ñas vacaturas tenham preferencia a outros quaesquer.

Era sem duvida inútil lembrar esta medida de equidade ao grande Napoleão; mas como $S$. M. I. e Real quer conhecer a nossa opinião em tudo o que nos convem, evidentemente nos prova que é mais pai do que soberano nosso, dignando-se consultar seus filhos, e prestar-lhes os meios para serem felizes. - Viva o Imperador."

«Projecto para a Constituição de Portugal», in Historia d'El-Rei D. João Sexto. Em que se referem os principaes actos, $e$ occurrendas do seu governo, bem como algumas particularidades da sua vida privada. Vertido do Francez pelo traductor da Cartilha do Bom Cidadão, Lisboa, 1838, pp. 179-181. 
DOCUMENTO II

\section{CONFUTAÇÃO}

do

celebre plano, que dizem fora feito por alguns afrancezados, e supplicado a Bonaparte, quando Junot mandou se pedisse novo Rey p. ${ }^{\text {a }}$ Portugal.

Responde: stulto juxta stultitiam suam, ne sibi sapiens esse viedatur. Proverb. Cp. 26.

Chegando inesperadamente á minha mão este infame papel, apenas o li, me pareceu logo que huma produção tão vil so em Loge de Pedreiros Livres podia ser forjada por algum jacobino Francez, ou por algum traidor afrancezado: julguei $q$. merecia m. ${ }^{\text {to }}$ ser encadernado em fogo, ou pelo menos analizado com as seguintes notas.

O papel principia assim:

«Os Portuguezes lembrados de serem de origem Franceza»

Nota Nenhum escritor Nacional ou estrangeiro houve ate agora tão estulto, que fizesse os Luzitanos descendentes originareos da França: nem os Poetas mesmos costumados a fabulizar jamais fingirão huma origem tão fabuloza, como esta q. o papelista quer dar aos Portuguezes. So quem for inteiramente Louco, he que acreditara a vilissima lembrança de tal origem.

P. «descendentes dos prim os conquistadores deste bello paiz em 1147, e de deverem á França sua Mãy patria o beneficio da independencia que tiverão como Nação em 1640».

N. Descendem sim os Portuguezes dos Conquistadores e Restauradores deste paiz q. expulsarão de Portugal os Sarracenos em 1147, e sacudirão o jugo castelhano em 1640. Mas esses conquistadores e restauradores erão Portuguezes e não Francezes, como he sabido e notorio em todo o mundo, sem haver jamais quem negasse esta verdade. Logo sem verissimilhança alguma nem Poetica quer o Papelista attribuir aos Francezes aquella conquista e Restauração de Portugal: e porisso $=$ mentitas est iniquitas sibi $=$ 
P. «não podem deixar de recorrer agradecidos $=$

N. Agradecidos porque? por invadir aleivozamente este Reino, pertendendo com palavra de proteç̧ão e amizade roubalo ao nosso legitimo Soberano? por atentar dolozam.te fazer ao nosso Principe e a toda a familia Real o mesmo q. fez ao Rey e a toda a Real família de Castela? por introduzir com falso pretexto de amigo tão malvados generaes como Junot, La Borda, Loizon, e outros taes comandantes de hum exercito de salteadores, impios Libertinos dezalmados que tem assolado os povos, roubado as cazas, assasinado a gente dezarmada, saqueado as Igrejas, profando os lugares S.tos, cometido os maiores sacrilégios, e mais horriveis dezacatos? por nos impor a iniquissima contribuição de quarenta milhões obrigando a comprar ou resgatar cada hum seus proprios bens? por sujeitar os Portuguezes a huma dezastrada policia fazendo Intendente delia // o façanhozo exfrade Lagarde, o qual não se contentando com encher de mentiras e falsidades todas as gazetas e papeis públicos, aterrou, prendeu, e atormentou todas aquellas pessoas q. sabia ou sonhava não serem afrancezadas? por desterrar, de Lisboa com o celebre nome de Deputação os Bispos e Fidalgos que forão a Baiona reconhecer vassalagem ou escravidão a

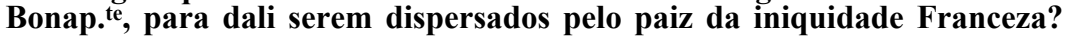
por abolir a nossa Regencia, o nosso Governo, a nossa Magistratura, os nossos Costumes, as nossas Leis? por desfazer os nossos Regim.tos, despojamos de todas as armas, apoderarse do nosso Erário, das nossas Fundições, dos nossos Arcenaes, da nossa Marinha? por compellir o resto da nossa tropa a marchar p. $^{\text {a }}$ França, e querer formar ainda mais huma conscrição de sincoenta mil Portuguezes conduzidos em gargalheiras para la servirem á sua ambição e ao seu capricho? por nos fazer seus escravos aomesmo tempo que protestava publicam.te ser protector e amigo?. São estes os beneficies porque lhe devemos ser agradecidos verdade he que se estes não merecem agradecimento, não ha outro algum que se lhe possa agradecer. Mas a q. ${ }^{\mathrm{m}}$ quer o Papelista q. recorramos?

P. «a paternal protecção, q. benigna lhes oferece o maior dos Monarcas q. jamais viu o Mundo»

N. Se maior de todos os Monarcas he ser o maior de todos os velhacos, de todos os ladrões, de todos os tiranos, he sem duvida Bonaparte como diz //0 lizonjeiro Papelista. Não falemos porem na sua benigna protecção; por ja todos sabemos por experiencia emque consiste a protecção Franceza: ate os rapazes da rua quando entre si discordão e se ameação mutuam.te pegando em huma pedra diz hum delles $=$ olha $q$. te heide proteger com esta pedra $=\mathrm{e}$ o outro grita $=$ hequadelRey que me protegem $=$ tal he a habilidade Franceza, que faz mudar o sentido usual das palavras p. $^{\mathrm{a}}$ o seu opposto!

P. «O grd.e e imortal Napoleão se dignou participamos pelos nossos Deputados a sua Imperial vontade $=$

N. Grande! emque? So em velhacadas roubos uzurpações enrredos compras de traidores e tiranias he que lhe pode competir o epiteto de grande, porque em nascimento, em accốes, em generozidade, e em complemento de promessas epalavras, ninguém he mais pequeno, mas assim mesmo participou aos traidores afrancezados a sua imperioza vontade que tem de acabar defundir este Reino. 
P. «quer que sejamos felices sempre ligados com os vinculos mais indissolúveis da nossa felicid e ao systema continental da familia Europea $=$

Como quer que sejamos felices, quem nos opprime com tantas violencias, com tantas extorsões, com tantas vexações, como temos experimentado e actualmente experimentamos? Como podemos ter felicidade estando prezos e atarracados com os durissimos // grilhões desse diabolico systema continental da tirania? quer sim o ambiciozo Napoleão a nossa felicid.e, não p.a nos, mas para si; quer q. sejamos tão felices como são os povos mesmo da França, etodos os mais por ella uzurpados. Mas emque consiste essa inculcada felicidade? Consiste em ser elle senhor absoluto, etodos os mais seus escravos: em ter cadahum continuo temores e sobresaltos, sem sosego algum nem segurança dos seus bens, e da sua propria vida: em pagar excessivas e horrorozas contribuições p. $^{\mathrm{a}}$ sustentar m.tos exercitos de salteadores e bandoleiros: em gemer debaixo do insofrivel pezo de multiplicadas conscrições militares p. ${ }^{a}$ o serviço do maior ambiciozo q. se tem visto: em ficarem os filhos sem Pays, e os Pays sem filhos, por lhe serem tirados com violencia, e conduzidos a paizes estranhos $p .^{\text {a }}$ militarem ahi segundo as ordens iniquas de hum pessimo conquistador: em se acharem todos sempre vacilantes, temerozos, faltos das ordinarias comodidades da vida, privados de todos os interesses e utilidades do comercio, e destituidos dos principais meios de subsistencia: consiste finalm.te em ver todos os direitos da natureza e da humanidade pervertidos, todas as leis divinas e humanas transtornadas, todos os povos desassossegados e cheios de afliç̧ão de susto e de mizeria, os melhores e mais antigos uzos e costumes nacionaes abolidos, os vicios computados por virtudes,

// e as virtudes por vicios a moral christam corrompidas pelas erradas Fl. $44 \mathrm{v}$. maximas da Libertinagem, o Evangelho a devoção e a piedade tratados com o maior desprezo e zombaria, a Religião verdadeira o Sacerdocio e o Ministerio do altar escarnecidos, o Clero Secular e Regular quazi expirando entre desprezos e calunias, a S.ta Igreja Catholica e Romana perseguida e consternada: tudo posto em dezordem confuzão e perplexidade. Ora eishai a felicidade que possuem todos os povos dominados por Bonaparte: eishai como quer q. sejamos felices ogrd.e Napoleão: eishai emque consiste a felicidade que tanto nos inculcão os Authores deste celebre papelote; os quaes pertendem achar felicidade no meio das mais horrivel desgraça!

Eque familia Europea sera essa tão obscura, que ha bem poucos annos ninguem a conhecia na Europa? Seja qual for, ella sempre he tal, que nem opapelista se atreve a nomeala.

P. «Quer que vivamos unidos, . $^{\text {a }}$ gozarmos finalm.te as doçuras de huma longa paz á sombra dos sabios governos q. institue fundados nas melhores bazes daLegislação da Liberdade dos mares $e$ do Comercio $=$

N. Bello! quer que descansemos vivendo unidos ao nosso maior inimigo: quer que gozemos de longa paz, quando nos está fazendo amais injusta guerra: quer melhoramos de go veno á sombra do seu tirânico despotismo: quer darnos Leis de liberdade dos mares e do comercio, que tenhão por baze a desmarcada ambição Napoleónica. Ha maior corja de contradições e paradoxos! 
P. «He isto pois onosso unico interesse, assim como o de todas Fl. 45 as Nações confederadas $=$

N. Longe va oseu agouro, forte Loucura! chama opapelista unico interesse aoque certam.te seria a mais lastimoza desgraça; porq. effeituandose a proposta ficaríamos de todo perdidos arrastados e reduzidos á mais mizeravel escravidão, assim como estão aOlanda, aDinamarca, aSuiça, Nápoles, a Italia, e todas as mais Nações confederadas com o ambiciozo Napoleão.

P. «Continua por tanto a nossa Deputação junto ao m.to alto Imperador e Rey a confirmar os nossos votos unanimes $=$

N. Continuará, continuará por sua desgraça essa chamada Deputação, não a estar junto a Bonap.te porq. nã̃o aquer aope de si, mas a ser por elle desterrada de Portugal, ecompelida a mendigar de porta em porta nopaiz inimigo asua subsistência da vida, como prezentemente acontece, quanto porem às palavras nossa e nossos q. opapelista junta às palavras Deputação e votos unanimes: se as refere a si e aoutros similhantes traidores afrancezados não repugno; porque ininguem melhor q. elle pode sentir os remorsos da sua ma consciência, e se as refere á Nação Portugueza ou aos legitimos Portuguezes: não ha sentido mais perverso, nem mais ridicula falsidade; porque todo omundo sabe a violência comque Bonaparte mandou e Junot obrigou os Bispos e Fidalgos a irem p.a Baiona em ar de Deputação, sem p. ${ }^{a}$ isso concorrer, nem tal approvar oReino dePortugal. Seguese portanto que essa Deputação não he dos Portuguezes, mas tãosom.te dos Francezes e dos traidores afrancezados.

\section{P. «e diga: Senhor $=$}

N. Não se deve chamar Senhor aquem he manifesto uzurpador; porque nenhum direito consente que os Ladrões fiquem sendo Senhores doque roubarão.

P. «Dezejamos ser ainda mais doque fomos quando abrimos o Oceano ao Universo inteiro $=$

N. He para rir, que opapelista queira q. sejamos mais ditozos sendo cativos, doque quando éramos Livres: sendo escravos, doque quando éramos Senhores: estando subjugados e opprimidos, doque quando éramos independentes: estando sujeitos a hum tirano orgulhozo, doque quando éramos vassalos de hum Principe benigno: gemendo debaixo do insoportavel jugo Francez, doque quando nenhuma oppressão nos fazia a Monarquia Portugueza: dominandonos hum Rey despótico estrangeiro, doque quando nos governavão com suavidade os Reys Legitimos Nacionaes de Portugal: dezeja em fim que seja possivel a impossibilidade, forte dezatino!

P. «queremos huma constituição e hum Rey constitucional, que seja Principe do Sangue da V. Imperial familia $=$

N. Quem são esses, que tendo huma Constituição fundamental das Cortes de Lamego, humas Leis ou Ordenações do Reino justissimas confirmadas pelo uzo de m.tos Séculos, e hum Rey ou Principe Legitimo nobilíssimo // pio virtuoso pacifico e descendente do prim. ${ }^{\circ}$ Rey 
dePortugal, como he oPrincipe Regente $\mathrm{N}$. Sr, querem antes . $^{\mathrm{a}}$ seu Rey hum petemetre corso plebeo estranho infiel intruzo parente sanguinário de Bonaparte? não são certam.te os fieis e honrados Portuguezes. São so huns poucos de vilissimos traidores afrancezados, que descartandose da razão da humanidade e da verdadeira Religião, eate dos sentimentos de honra evergonha, preferem um ridiculo intruzo aoseu Legitimo Soberano: damesma sorte que huma quadrilha de malvados Ladrões se escolhe p. $^{\mathrm{a}}$ seu comandante outro tal como elles. Mas dezejam isso embora os taes rebeldes: digãonos pelo menos quem haviade fazer essa decantada constituição, e nomear esse fantástico Rey? O seu grd.e Napoleão? e donde lhe veio ajurisdição o dominio eopoder de legislar a Nações alheias nomear Rey de Portugal? emque Codigo divino ou humano, publico ou municipal, eccleziastico ou civil se acha esse Direito? so na esquentada cabeça do impio Hobbes, do execrando, Machiavel, e dos Jacobinos Authores, deste papelote he q. se achava, eporisso lhe não podia vir senão do inferno.

P. «Somos contentes, com huma Constituição q. seja em tudo sirnilh.® á q. V.M.I. e R. houver por bem dar aoDucado de Varsóvia, alterandose unicam.te o modo de eleger os representantes Nacionaes, oque deve ser pelas Cameras, p. $^{\text {a }}$ melhor confirmarem nossos antigos costumes $=$

N. Contentãose os taes rebeldes afrancezados com a Constituição ou Alcorão dado a Varsóvia // emque Bonap.te transtornando todos os direitos, confundindo todas as propriedades, e mudando todos os dominios fez oque lembrou a Horacio= diruit, adificat, mutat quadratu rotundii = Não podia comtudo esse dezatinado codigo deixar de agradar aos taes requerentes; por que basta ser obra iniqua de Bonap.te p. ${ }^{a}$ ser como elle he, e como elles são. Admirame porem oserem elles tão eserupulozos na eleição dos representantes, e nenhum escrupolo terem de aprovarem os paradoxos substanciais do tal codigo ou alcorão! Lembraome os farizeos que escrupolizavão de não pagarem dizimo dos caminhos, mas de não pagarem do trigo nada escrupolizavão. munto escrupolo nas couzas leves ade pouca ou nenhua importância, e nenhum nas graves e interessantes: m.ta exacção nos accidentes e nenhuma na substancial! fortes Doutores são os Jacobinos!

P. «Queremos huma Constituição q. bem como ade Varsóvia a Religião do Estado seja a Catholica Apostólica Romana: protestando pela conservação de todos os principios da ultima Concordata do Império Francez com a Sé Romana =

N. Se pela Religião do Estado entendem os representantes afrancezados q. a Religiã̃o Catholica Ap.ca Romana seja a do Governo e Ministério, deixando atodos os mais a liberdade da Religião que quizerem: vem a ser omesmo q. desgraçadam.te sucede em algumas terras da Alemanha emq. o Governo he Catholico Romano e o resto dopovo he protestante, assim como em outras sucede pelo contrario ser opovo Catholico e o Governo heretico. e se pela Religião doEstado entendem ser a Religião Catholica // a de todo o Reino de Portugal: parece mais hum disfarce politico, doque huma sincera vontade; porque logo imediatam.te protestão pela introdução de todos os principios da ultima Concordata concebida em termos simpleces edemaziadam.te sinceros, abuzou tanto o Ministro dos Cultos Francez/eprotestante/com aprovação do Senado e consentimento de Bonap.te, que

Fl. $46 \mathrm{v}$. 
oPapa se viu obrigado a reclamar como na verdade reclamou em pleno Consistorio dos Cardeaes contra os artigos, addições e interpretações feitas pelo tal Ministro dos Cultos, queixandose solenemente a Bonap. ${ }^{\text {te }}$ daquelle intolerável abuzo. Sendo poes apostulação dos afrancezados no segundo sentido, não dá pequena suspeita de que so querem Religião á Franceza.

P. «Que todos os cultos porem sejão Livres, públicos e civilmerte tolerados $=$

N. Agora sim! que acabarão os requerentes de tirar a sua mascara, declarando abertamente nesta propozição, qual seja osentido da sua pretendida catholicidade, querem o tolerantismo publico de todas as seitas. E como a verdadeira Religião e Igreja de Jezus Christo não pode misturarse, nem aprovar, nem admitir essa publica tolerância de falsos cultos; porq. assim // como so pode ser huma a verdadeira Religião so pode ser hum oculto verdadeiro, e so este pode ser licito e consentido. Seguese bem claram. ${ }^{\text {te }}$ que os taes requerentes afrancezados so querem o Libertinismo Francez, e não o catholicismo da Santa Igreja Romana, eque deixão a Religião Catholica, para seguirem a de Bonaparte, que no Egipto he mahumetana, nas outras terras he a dopaiz, ou p. ${ }^{a}$ melhor dizer he he nenhuma em toda a parte.

P. «Que todas as Cidades sejão eguaes ante a $L e i=$

N. He capcioza apalavrinha ante a Lei, com aqual pertendem enganar os simpleces, fazendolhe crer que podem ter igualdade com os deziguaes, quando não so na terra mas ate no Ceo ha gerarquias superiores $\mathrm{e}$ inferiores. Mas essa cantilena da igualdade e Liberdade já não voga, ja se acha antiquada edesvanecida ha munto tempo por aquelles mesmos q. a inventarão, ja todo omundo sabe que em França tudo he dezigual, eque omesmo Napoleão ja extinguiu essa farça. Debalde pois pertendem os afrancezados renovar essa cantilena. partamentos $=$

P. «Que onosso território Europeo seja dividido em oito De-

N. Que mal dividido está Portugal em seis Províncias? pa que he multiplicar entidades sem necessidade? Com essa multiplicação de Províncias ou Departamentos não se augmenta mais o território; eporisso tanto importa q. se faça essa divisão em oito como em seis partes domesmo terreno, sempre este fica sendo domesmo tamanho que era. So o espirito da inovação e da inversão he que pode sugerir lembrança tão ridícula.

P. «Quê as Diocezes sendo reguladas por esta divisão civil admitião somM hum Arcebispo e sete Bispos =

N. Os bons Catholicos dezejão que onumero dos Bispados se augmente, p.a que os diocezanos sendo menos em cada Dioceze sejão melhor e mais facilm.te dirigidos e governados pelos seus Bispos: os afrancezados querem que os Bispados, ja q. não podem extinguilos de todo, pelo menos sejão diminuídos, p. $^{\mathrm{a}}$ que a vinha do Senhor não seja bem cultivada. $O$ amor que os bons catholicos tem á observância dos preceitos e conselhos do Christianismo, he quem lhe faz dezejar maior numero de Pastores que apascentem o rebanho de Jezu Christo: oodio, 
que os afrancezados tem á Religião Catholica, he quem lhe faz apetecer a extinção ou diminuição dos q. dirigem as almas no caminho das virtudes e da perfeição christam. Os bons Catholicos olhão para oCeo ep. ${ }^{\text {a }}$ os que podem conduzilos, p. $^{\text {a }}$ agloria eterna: os afrancezados olhão so . $^{\text {a }}$ aterra ep. ${ }^{\text {a }}$ os interesses temporaes, sem fazerem cazo algum dapiedade doEvangelho da eternidade. Os bons catholicos seguindo o exemplo dos Santos e imitando os antigos fieis venerão um S. ${ }^{\text {to }}$ Henriques hum S. ${ }^{\text {t0 }}$ Estevão, hum S. Luiz hum S. Fernando e outros S. tos Reys e Imperadores, que fundarão m.tas Igrejas, e erigirão m.tos Bispados: os afrancezados louvão os impios, eseguem os tiranos que assolarão os templos, destruirão as Igrejas profanarão os Lugares Santos, e extinguirão // as Diocezes, como fizarão os Tiranos antigos, como fazem Bonap.te eos seus exercitos, e como querem fazer os seus sequazes, tal he adiferença de fieis aos infiéis, de Catholicos aos afrancezados! He necessário por tanto concluir que aquelles são inspirados por Deos, e estes sugeridos por Satanaz: aquelles seguem os dictames da virtude, e estes as maximas da impiedade: aquelles servem a Zezu Christo, e estes servem a Napoleão eaodiabo: aquelles merecem ser premiados com gloria eterna, e estes castigados com penas eternas: que desgraçada sorte ados afrancezados!

P. «Que as nossas Colonias fundadas e regadas com onosso sangue pelos nossos antepassados sejão consideradas como Provincias ouDepartamentos anexos ao nosso Reino, eque os seus reprezentantes, sendo ja chamados, achem na nossa Constituição os titulos que lhe competem, logo q. queirão oupossão vir ocupar os lugares da sua reprezentação $=$

N. Não ha Loucura mais vam nem mais ridicula, doque estar gastando tempo em fazer planos aereos, Departamentos quiméricos, edivizÕes imaginarias de terras alheias que nem justa nem injustamente se possuem Loucos afrancezados que poder tendes vos de repartir e dispor de bens alheios que de nenhum modo possuis? poraue titulo vos pertence e aos Francezes ofazer Departamentos e divizões dos Brazis, das Ilhas, e das // mais terras que chamais Colonias? porventura he menor odominio apropried.e eaposse que os habitadores das Ilhas edo Brazil tem dos seus bens moveis ede raiz naquelle terreno, doque o dominio propriedade eposse que vos tendes dos vossos bens em Portugal? acazo não são huns eoutros igualmente sujeitos aoPrincipe Regente $N$. Sr não he igualmente Soberano detodos omesmo Monarca, aquem so pertence a dispozição egoverno assim das Ilhas e Brazis, como dePortugal? então porq. titulo auereis dispor das terras a. são dos Ilheos edos Brazileiros? eporq. titulo pedis a Napoleão aue faça esses Departamentos em terras q. não são suas nem vossas porque lhe não pedis q. faça Departamentos na China, no Japão, na Rússia. nalTurauia? porq. nesses paizes nem justa nem injustam.te domina enos Brazis, nas Ilhas tem algum dominio propriedade ou posse? nem justa nem injusta. Em Portugal teve por algum aindaque pouco tempo, otal Napoleão aposse que tem hum ladrão naauillo aue furta; porem nas Ilhas nos Brazis e mais terras, q. chamais Colonias nem essa mesma posse de ladrão teve nem tem, como sabe todo o mundo e vos mesmos não podeis negar, não tendo poes ali dominio nem propriedade nem ainda posse injusta odecantado Napoleão, como hade fazer esses Departamentos que lhe pedia? Logo as vossas supplicas são tão ridiculas, como são quiméricas esses Departamentos supplicados. 
P. «Que no Ministério haja hum Ministro encarregado da Fl.49v. instrução publica alem dos outros que forem necessários $=$

N. Como ja os Authores deste papelote em outro artigo antecedente tinhão pedido a intolerável tolerância de cultos públicos de quaesquer seitas, sem nenhuma exceptuarem, e agora pedem hum Ministro principal ou authentico encarregado da instrucção publica; bem se deixa ver que esse authentico Ministro q. pedem, he paraque haja em Lisboa Ministro dos Cultos de todas as seitas assim como ha em Paris: eque os outros q. dizem necessários, são Ministros particulares de cada seita encarregados de instruirem os sectários delia nas maximas erradas que lhe sã̃o próprias, como em França tem os Lutheranos, os Calvinistas, eoutros taes. Não me admiro deque Jacobinos queirão Ministros que promovão e ensinem o Jacobinismo oCalvinismo, ofilosofismo opedreirismo em Portugal: mas admirome deq. assim mesmo queirão ser ainda tidos e reputados por Catholicos Romanos! Como se podesse concordar a verdade com a mentira, a luz com as trevas, Christo com Belial!

P. «Que opoder executivo se institua por hum Conselho de Estado e sejão os seus decretos cumpridos por Ministros q. fiquem responsáveis pela sua execução, eque o poder Legislativo se divida em duas Cameras, e se comunique com o executivo $=$

N. Estes SJS afrancezados tudo querem á Franceza: que se mudem os uzos e costumes, que se mudem os poderes, que se mudem as Leis, que se mude odireito, que semude ou transtorne tudo. ep. ${ }^{\text {a }}$ que p. ${ }^{a}$ ser tudo á // Franceza. eque proveito vem a Portugal de todas essas mudanças? fica tendo melhor Legislação, mais bem fundada na razão, na justiça na equidade? não. Mas dezejão os afrancezados q. as Leis os costumes a Religião tudo seja á Franceza, porq. sem isso lhe não achão graça, nem gosto os seus estragados paladares, eisahi todo omotivo de quererem tão extravagantes e ridiculas mudanças.

P. «Que a ordem judiciaria seja independente e julgada pelo Codigo Napoleão $=$

N. Eisaqui hum bello rasgo da mais podre lizongea, ou huma lizongeira thurificação, comque os afrancezados incensã̃o oseu idolo Napoleão. Mas os Codigos Napoleões são muntos, munto vários, e munto exoticos e ainda se não sabe quantos fara mais aquella inconstantissima cabeça, por qual delles querem os S.rs afrancezados q. seja formada a ordem judiciaria? elles não odeclarão mas pareceme que seja qual for, com tanto que seja de Napoleão, por mais iniquo mais ilegal e mais esdruxolo q. se considere, ficarão satisfeitos; porque basta ser obra de Napoleão p. ${ }^{\mathrm{a}}$ merecer os seus aplauzos, aindaque omundo inteiro a tenha pela mais indigna q. se tem visto, tal he a submissão e respeito que tributão a Napoleão os seus sequazes!

P. «Que os crimes sejão julgados publicam.te com justiça ebrevidade. Que todos os Funcionários públicos sejão os mais benemeritos de entre os Nacionaes, como se determina no tt. 11. dad.a Constituição Polaca $=$

N. Os A.A. deste ridiculo plano sem duvida pozerão aqui estes dois artigos, p $^{\text {a }}$ que se entenda serem homens de inteireza e equidade, aindaque ninguém sepossa capacitar deque tal casta degente // tenha

Fl. $50 \mathrm{v}$. 
inteireza ou equidade. Mas tem sua graça opedirem para Funcionários publicos os mais beneméritos, quando se sabe que la no seu partido so se entendem outros taes afrancezados como elles. no Imperio Francez =

P. "Que haja Liberdade de Imprensa, como se acha estabelecido

N. Emque consiste a Liberdade de Imprensa em nenhuma outra couza mais doque poder cadahum livremente dar ao prelo os escritos ou papeis que quizer sem dependencia de revizão eLicença, por mais perversa que seja a doutrina que se imprime. Eque proveito pode trazer aopublico principalm.te catholico essa liberdade de imprensa? Os concilios geraes, os Sumos Pontifeces, os Soberanos Catholicos, etodos os homens doutos da Igreja Catholica conhecerão ejulgarão sempre, conhecem e julgão que a imprensa livre de revizão elicença não só he inútil mas danoza aopovo catholico; eporisso aprohibirão, aprohibem severamente compenas gravissimas espirituaes e corporaes: eassim se tem conservado sempre prohibida em todos os séculos desdeque ha imprensa ateagora. porem os sofistas incrédulos chamados filósofos da moda, os Libertinos, os Hereges, eos revolucionarios, afectando saberem mais, eterem maior zelo dobem publico doque tantos Concilios Geraes, tantos Papas, tantos Soberanos Catholicos, e tantos homens doutos da Igreja catholica principiarão, e continuão a declarar contra a necessidade de revizão e licença, por não quererem suportar esse freio dos seus dezatinos.

$\mathbf{E}$ para que requerem, ouparaque serve aos taes requerentes, eaos seus socios Nacionaes eextrangjos essa Liberdade de imprensa? para imprimirem falsidades, enredos satiras; para propagarem doutrinas perversas, maximas // sediciozas, dictâmes diabolicos; para declamarem contra a Religião, contra apiedade contra a virtude; para dezafogarem os seus odios, as usas iras, as suas paixoens; para formarem libellos infamatorios, denigrirem afama dos homens bons, escarneceram das pessoas devotas, confundirem a virtude com o vicio, introduzirem sedições e rebelliÕes, revoltarem os vassalos contra os Reys, os soldados contra os Generaes, os Catholicos contra oPapa, os homens contra Déos; como fizerão os sofistas libertinos nessa infinidade de papeis impressos em imprensa clandestina, ou Livre pouco antes da Revolução Franceza como consta desses mesmos Livretos revolucionarios que ainda existem: fazendo talvez maior guerra áEuropa com papeis impressos na imprensa Livre ou Libertina, doque lhe tem feito com armas deferro efogo.

Eisaqui paraque tem servido aos sofistas incredulos, eparaque pode servir aos novos requerentes essa funestissima liberdade de imprensa, aqual nunca jamais serviu, nem costuma servir para ensinar boa doutrina e refutar erros, senão para os semear, ou espalhar, e introduzir por esse modo a liberdade de abraçar falsas religioens, sem receio de serem punidos os seus authores, e cooperadores. Eainda havera quem approve tão iniquo requerimento: quem proteja tão absurdo systema: quem queira seguir antes os falsos dictâmes dos taes requerentes e dos filozofos Libertinos, doque os preceitos e sentenças dos Concilios Geraes, dos Sumos Pontifices, dos Soberanos Catholicos, adetodos os homens sabios do Christianismo? So hum Bonaparte, ou hum inimigo declarado da Igreja Catholica, poderá tal querer, tal approvar, tal proteger. 
N. Se apalavra nossa significa adecadência dos AA. deste papel, ede outros similhantes afrancezados cauzada pela sua ignorância epelos seus erros, não me opponho á sua própria confissão. Mas se por essa palavra querem atribuir atai decadência á Nação Portugueza, não ha insolência maior, nem falso testemunho mais claro, porque nem as artes, nem as sciencias, nem o comercio, nem apolicia, nem a Christandade, nem couza alguma publica se acha decahida em Portugal, antes se ve tudo melhorado.; como he notorio atodos extrangeiros e nacionaes: senão apareça cum so ponto ou ramo dessa sonhada decadência deste Reino. Logo so nos rebeldes afrancezados. he que ha não so decadência, mas inteira falta de sciencia, verdade, Religião, honra, brio, e fidelidade.

Supponhamos porem entretanto que atai decadência era verdadeira assim como he falsa, para remediala he impossivel que fosse melhor a liberdade de imprensa, doque a impressão dependente de revizão eLicença. porque a utilidade da imprensa não nasce da Liberdade de imprimir, mas da bondade dos manuscriptos que se imprimem; como he bem claro, pois que tanto se podem imprimir os bons como os maos. para se conhecer se he boa ou ma adoutrina dos manuscriptos. heque sefaz revizão delles: a tanto que se conhece ser boa a sua doutria, se da logo licença para se imprimirem, sem haver dificuldade alguma de concedela. he isto mais conforme á razão, mais util aopublico. //emais capaz de remediar essa decadência se a houvesse he sem duvida. Seguese por tanto que ainda nesse fingido cazo não era melhor remedio dadecadencia a imprensa livre doque a dependente de revizão e licença: eque para requerer, ou approvar a Liberdade de imprensa he necessário ser Libertino, ou outro tal como os requerentes deste papelote. circulação»

P. «Que os bens de corpos de mão morta voltem todos á

N. O odio e raiva que os impios tem á Igreja Catholica, e aos Ministros do altar he que instigou os Valdenses condenados pelo Concilio Constanciense, edepoes delles os Lutheranos, os Calvinistas, os Volterianos, os Illuminados da Baviera, os Jacobinos da França, eoutros similhantes arquitectos da impiedade aprocurarem com diversos preteistos extinguir todas as corporações eccleziasticas Regulares eSeculares, buscando para isso todos os meios, que o inferno lhe sugeria, ecomo estes sãos Corifeos, aquem os afrancezados auctores deste papel querem imitar, pedem agora neste artigo ao furiozo protector da incredulidade que os bens dos corpos que chamão de mãos mortas voltem á circulação, paraque não tendo estes Corpos ou Corporações Regulares e Seculares comque subsistir, acabem e se extinguão porsi mesmas. Não he munto porem que os taes afrancezados seguindo operverso exemplo dos seus já dictos antesignanos projectassem tão horrivel iniquidade: ornais he que este mesmo iniquissimo projecto esteja (corrigido para estava) segundo a forma publica /decretado pelo monstruozo Napoleão, e ao ponto de se executar, se antes dessa fatal execução não nos acudisse Deos, e livrasse // d e tão cruéis executores, destroçando como destroçou, elançando para fora deste Reino aquellei nfame exercito de bandoleiros Francezes que nos roubavão, opprimião etiranizavão. Oxala que tãobem fossem com elles os seus sequazes, para ficarmos inteiramente livres dos que nos per- 
turbão e inquietão, como aos da Galacia dizia S. Paulo — utinum abscindantur, qui vos conturbant $=$

Estimaria comtudo medicassem esses grandes politicos afrancezados, qual seja o emolumento (?) que dahi possa rezultar aopublico principalmente catholico. eu certamente não conheço tal melhoramento. oque sei, e sabem todos he, que o estado emque agora, desde ha muntos séculos se achão esses bens, forão postos e dedicados aDeos pela piedade dos Imperadores Catholicos, dos Reys Santos e dos fieis devotos, que fundarão, edotarão legalm. ${ }^{\text {te }}$ estas corporações: e no estado emque os dezejão ver esses afrancezados, he a de serem postos em almoeda e uzurpados pela impiedade de hum Imperador iniquo de Reys incrédulos, e de Libertinos infiéis, que pertendem destruir e anihilar todas as Corporações eccleziasticas, deicandoas á sua ambição. No estado prezente se achão applicados ao culto de Deos, á veneração dos Santos, ao ornato dos altares, e á conservação dos templos elugares pios: e no estado dessa revolta ornais provável he que só aos idolos da ambição, da luxuria, do orgulho, e das libertinagens se applicarião. No estado prebente servem para côngrua sustentação dos Ministros de Jezu Christo, que administrão os Sacramentos, ensinão os preceitos da Lei de Deos, pregão a doutrina Santa doEvangelho, orão pelos Princepes epelos Estados, e offerecem sacrifícios ao Altissimo por todos os povos, e no estado dessa revolta paraque hãodeservir, senão para enriquecer e sustentar os incrédulos que mais capazes forem de plantarem o Libertinismo, depropagarem opedreirismo, defomentarem a rebelião, ede espalharem as perversas maximas da impiedade?

No estado prezente são como erários municipaes ou montes depiedade, donde se alimentão pobres, socorrem necessitados, acodese aquaesquer calamidades publicas, e se contribue para os gastos da guerra edefeza da patria, como actualmente se está vendo: e no estado dessa revolta, em pompas vaidades bailes, brincos, divertimentos, banquetes, teatros profanos, e outras couzas ainda peiores he que haviãodegastarse, como se tem experimentado nesses desgraçados paizes, emque os Jacobinos Francezes fizerão essa impia revolta de todos os bens eccleziasticos. O estado finalmente emque se achão os bens, que possuem as Corporações que chamão de mãos mortas, he oque adquirirão juridicamente em muntos séculos por todas as Leis divinas e humanas, eccleziasticas e civis: e o estado que os afrancezados querem darlhe he o do roubo da injustiça, e da impiedade, contrario nãoso atodo odireito, mas atoda a humanidade.

Julguem agora todas as pessoas sensatas, qual destes dois estados de bens he melhor, mais racionavel, mais conforme atodo o direito, e mais util aopublico: se oque lhe derão os seus proprios instituidores, se oque lhe procurarão dar os iniquos invazores: se oque lhe deu a piedade Catholica, se oque lhe quer dar a impiedade Franceza: se o estabelecido pelos fieis Catholicos com posse imemorial de tantos séculos, se odezejado pelos requerentes afrancezados com tão iniquo pretexto ecom tão impia novidade, persuadome que ninguém deixara de preferir oprimeiro ao segundo estado, nem de conhecer, que para solicitar o contehudo na supplica deste artigo he necessário ser totalmente Libertino, on mentecapto.

P. «Que a distribuição dos impostos seja proporcionada às posses ebens de cada individuo, semque alguns fiquem izentos de pagalos, procurandose que a sua arrecadação seja facil e suave» 
N. Não cuidava que fossem tão severos huns supplicantes tão submissos. Em todas as idades do mundo houve sempre izentos eprivilegiados. Ao que vencesse ogigante Goliat no tempo de Saul se prometeu, econcedeu ficar a sua caza izenta de tributos para sempre: esta mesma izenção se concedeu depões a muntos Hebreos benemeritos, e aos Levitas: entre os mesmos Gentios Gregos, e Romanos erão izentos eprivilegiados os Grandes Generaes, eos Sacerdotes dos falsos deozes: na Lei da Graça forão izentos muntos homens valiozos e assinalados no serviço edefeza da patria, etãobem os eccleziasticos por devoção epiedade dos Imperadores Catholicos, desorte que so os depouca ou nenhuma piedade lhe não concederão essa izenção de impostos. Agora os afrancezados, para inovarem, e transtornarem tudo, querem que não haja tal izenção depessoa alguma. Seja Mas confessem que so os Ímpios ebarbaros assim fizarão, eque isso aprenderão os AA. deste iniquo plano da fantastica igualdade que os Jacobinos sonharão, eja como sonho ou fumo se desvaneceu.

P. «Que a divida anterior doEstado em toda a sua extensão seja consolidada egarantida, poes não faltam meios para o conseguir»

N. Este artigo não he mais que pura quimera forjada na cabeça dos taes requerentes, ou mera questão de sujeito que não he, eque por si mesma se desvanece: nem serve senão de manifestar a extravagancia de tal requerimento,

P. «Queremos igualm. ${ }^{\text {te }}$ que a organização dos Corpos de administração Civil, economica, ejudiciaria seja reformada com amesma sabiduria, que tanto tem feito prosperar o Império Francez»

N. Se estes ridículos afrancezados não estivessem tão costumados a lizongear e mentir, em lugar da administração sabia, devião chamarlhe administração infernal; porque na verdade infernalmente tem sancionado, efeito servir aos seus depravados intentos não a sabiduria, mas a diabólica astúcia daquelle monstro, que halucinou os Francezes: e em lugar daprosperidade do Império Francez, devião dizer que a iniquissima administração civil, economica, ejudiciaria estabelecida por Bonaparte detal modo tem deslustrado confundido edezacreditado a Nação Franceza, que não ha canto algum em todo omundo, emque não seja tida e havida por incapaz de comunicação e comercio com gente alguma. $E$ isto he tão certo etão notorio, que nãoso os povos civilizados mas ate os Mouros eos Barbaros assim o attestão nos seus papeis públicos. seja reduzido»"

P. Eoor conseguinte que onumero dos Funcionários públicos

N. Querem os afrancezados diminuir onumero dos Parrocos, dos Conegos, dos Beneficiados, dos Presbíteros, dos Confessores, dos Pregadores, ede todos os que exercem funções eccleziasticas, aquechamão / talvez por desprezo / Funcionários, assim como já disserão dos Dispôs eDiocezes. Eparaque? bem claro he: para se augmentar onumero dos Libertinos, dos incrédulos, dos pedreiros Livres, dos Jacobinos Francezes eafrancezados. // porque se forem poucos aquellesque se empregão no culto divino, na administração dos Sacramentos no ensino da doutrina christã aopovo, napregação doEvangelho, na direcção das almas fieis para oCeo, ficão os pedreiros afrancezados com menos 
contrários, e mais facilidade para semearem os seus erros, perverterem os simpleces, corromperem os povos, epropagarem as suas depravadas maximas entre os que não souberem dissolver, oufugir dos seus paleados enredos. Devem porem advertir os taes requerentes e seus socios que nem toda a força ds Napoleões, nem toda a astúcia dos Jacobinos, nem todas as intrigas dos afrancezados, nem as portas do inferno hãodeprevalecer contra a fe, contra oEvangelho, contra a S.ta Igreja Catholica Romana. Acauza he deDeos; $e=$ non est sapientia, non est prudentia, non est consilium contra Dominum. $=$

P. «Mas dezejãmos epedimos que atodos dimitidos sejão vitaliciamente conservados os seus ordenados ou pensoens relativas aos cargos, officios ou Beneficios, deque ficarem destituidos, eque vagando qualquer emprego, etc. seja dado com preferencia, se tiverem merecimento e bons costumes»

N. Na petição deste artigo mostrão os requerentes compaixão com os dimitidos; por saberem munto bem que oseu despacho haviadeser=não ha que deferir $=$. fingamos porem que o seu grd.e Napoleão nãoso despachava $=$ como pedem $=$ mas solenemJe prometia cumprilo. Eque importava isso? elle cumpriu jamais a sua palavra, ou as suas promessas? haja vista aos Sacerdotes Seculares e Regulares daltalia eda Alemanha, aquem despojou dos seus empregos, edas suas rendas, prometendo darlhe côngrua sustentação: eateagora nada lhe deu. haja vista aos Funcionários mesmo da França, aos quaes nunca pagou oque selhe tinha prometido. // haja vista aoutros quaesquer eccleziasticos, aquem prometesse alguma côngrua oupensão, eapareça huma so vez que cumprisse a sua promessa. He liberal em prometer, mas em cumprir, he como odemonio, que promete munto, enão da nada.

\section{P. «Escuzado era lembrar esta medida de equidade»}

N. Assim he; porque não ha couza mais supérflua, doque supplicar aquem se sabe de certo, que não hade conceder, oque selhepede.

\section{P. «A sabiduria e humanidade do grande Napoleão»}

N. Sim: a sabia humanidade dogrd.e Napoleão he tão rara e tão notoria como a de Nero, como a de Attila, como a de Gensérico, a de outros similhantes monstros da crueldade, que infestarão este mundo. $E$ bem se tem mostrado na barbara insolência, comque tem tratado o Papa, depões de lhe ter feito tantos, etaes obzequios, maiores sem duvida doque podia, edoque devia, bem se ve na horrivel velhacada, que fez ao Princepe Regente dePortugal não so quebrantando o solene tratado de neutralidade comprada por doze milhoens, mas tãobem invadindo este Reino com hum exercito de Vandalos salteadores, aomesmo tempo, que protestava huma sincera amizade. Bem se manifesta na traição aleivozissima, que praticou, e está prticando com os Reys de Hespanha, prendendoos atraiçoadamente com um osculo depaz e amizade, e extorquindo com dolo eforça a mais violenta renuncia daCoroa de Castela: e isto depões de lhe ter amigavelmJe exhaurido oErario tirado as armas, e as tropas, eprotestado solenemente ser seu amigo intimo, ealiado. bem se deixa ver finalmente em todas as mais occaziões, que pode invadir, assolar Cidades, Provincias eReinos. tal he a humanidade sabia de Bonaparte! eainda os authores deste papel tem boca para falar em tão execranda humanidade! oh têmpora! oh mores! 


\section{Revoltas e Revoluções}

P. «Mas querendo S. M. I. e R. a nossa opinião sobre tudo oque nos convém, danos evidentes provas de ser ainda nosso Pay, dignandose consultar os seus filhos e liberalizar os meios da sua prosperidade»

N. Gloriãose os requerentes afrancezados de chamarem Seu Pay ao monstruozo Napoleão; sem advertirem que hum monstro não pode ser Pay, senão de filhos como elle. Eu não lhe envejo essa honra, gozem delia quanto ecomo quizerem:' contando que se não queixem, se Ihe dedicarem $=$ vos ex patre diabolo estir $=$ como disse Christo aos farizeos.

P. Concluem ultimam.^ ${ }^{\wedge}$ ooseu papel dizendo «viva Napoleão ogrande, e viva a sua Dinastia»

N. Viva m.t0 embhora; mas viva sem armas, sem tripas, sem exercitos, sem sequazes, sem Império, sem comando algum civil ou militar. Viva: mas de sorte que morra a sua soberba a sua ambição a sua impiedade a sua tirania oseu orgulho asua aleivozia a sua crueldade oseu furor, comque tem assolado toda aEuropa. Viva emfim; mas viva em estado, que se arrependa dos seus pecados, chore as suas culpas, confesse as suas maldades, deteste os seus crimes, faça penitencia dos seus delictos, restitua oque tem uzurpado, abjure os seus erros, e se reconcilie com a S.ta Igreja Catholica Romana, aquem tão barbaramente tem perseguido: se não quer arder eternamente com os demonios entre os condenados do inferno. Equanto á sua dinastia, como he tão infézada, e ainda está por nascer pouco ou nada importa, se abortar.

Manuscrito 1664 da Biblioteca Geral da Universidade de Coimbra. (*)

0) Este documento foi parcialmente publicado em Maria Ermelinda de Avelar Soares Fernandes Martins, Coimbra e a Guerra Peninsular, t. II, Coimbra 1954, pp. XIII-XIV. 